

\begin{abstract}
SUMMARY OF PUBLIC COMMENTS
TO THE NEW MEXICO STATE DIRECTOR'S

WILDERNESS STUDY AREA RECOMMENDATIONS
\end{abstract}

LIBRARY COPY

Prepared by

Division of ResourcesI/

New Mexico State office

USDI Bureau of Land Management

September 1980

1/ The Public Input Analyşis Team included Dan Wood, project supervisor, Ben Fish, project leader; Kent Carlton, Donita Cotter, Buzz Hummel and Angie Berger, team members.

BLM Library

Denver Federal Center

Bldg. 50, OC-521 


\section{CONTENTS}

INTRODUCTION

PUBLIC INPUT ANALYSIS

REPORT FORMAT

ANALYSIS RESULTS

Part I - Summary of Demographic Data and General Comments

Demographic Data

Table 1 - Type of Input

Table 2 - Group Type of Respondent 9

Table -3 - Geographic Distribution of Input's Origin 10

General Opinions and Comments

Table 4 - Balance of Opinion on the Concept of Wilderness in General

Table 5 - Balance of Opinion on the BLM Wilderness Inventory Results

Table 6 - Balance of Opinion on Public Involvement Methods

Tabie 7 - Summary of Opinions Expressed at Public Meetings

Table 8 - Variation of Opinion by Geographic Origin 23

Table 9 - Ten Most Discussed Units

Table 10 - Other Issues Discussed

Part II - Summary of Unit Specific Comments

Albuquerque District (010)

Socorro District (020)

Las Cruces District (030)

Roswel1 District (060)

Glossary 


\section{INTRODUCTION}

During the spring and early summer of 1980, the New Mexico State Office of the U. S. Bureau of Land Management asked the public to comment on its Proposed Wilderness Study Area (WSA) Decisions. In this proposal, the BLM recommended almost 900,000 acres for wilderness study. This was the result of intensive inventory for wilderness characteristics on about 2.2 million acres of public land.

Public comments on the BLM WSA proposals were solicited in a variety of ways. Open houses, to explain BLM's proposals, were held in eight selected locations in the state during early April. Public meetings, to solicit oral public comments, were also held in ten selected locations in May and June. Numerous personal contacts were made with individuals, special interest groups and state and local government officials. In addition, the BLM encouraged written comments as the primary public input method. All comments, written and oral, received through August 15, 1980, are included in this analysis effort. Comments received after that date are not included in this analysis. However, those comments were reviewed individually and considered prior to the fina1 WSA decision.

The BLM's effort resulted in receiving about 700 personal inputs, 700 form letters and 2,300 coupons. These coupons were attached to a poster which was distributed nationally by a special interest group. People were asked to remove the coupon, which had a standard printed message, sign it and send it to the appropriate State Director.

The information contained in these public inputs is summarized in this report. 


\section{PUBLIC INPUT ANALYSIS}

The purpose of this analysis is to objectively identify and display the nature and extent of the public input received which discussed the BLM's WSA proposals. This analysis report is a summary display of the analysis efforts. The analysis does not evaluate the value or importance of the comments received. These judgments are made by the District Managers and the State Director. These judgments are reflected in the decision rationale which is developed for each wilderness inventory unit which was intensively inventoried. These decision rationales will be available at the District Offices after the WSA decisions are announced.

The method used to analyze these comments was a content analysis system using Codinvolve techniques. This system is specifically designed to provide an objective display of the nature and extent of the contents of numerous and diverse public inputs.

The basic concept of this system is that the common denominations of virtually all public input are opinions offered for, against or about the issues in question, along with the reasons that may be given to support the opinion. The number and kinds of supporting reasons can vary considerably, even when those given support the same opinion.

The basic goal of a systematic analysis of public input is to identify and display the opinions and supporting reasons contained in the public input and how they differed according to other variables that may be important, e.g., form of input, respondents' residence, etc.

The system used for this analysis had several steps:

1. Identify basic questions for which the decision-makers need answers. These questions include: Where do the publics disagree with the BLM recommendations? What reasons were given? Is our inventory accurate? Who agrees and disagrees with our subjective judgements, such as apparent naturalness and solitude and why?

2. Survey the inputs to determine the breadth of issues discussed.

3. Develop a code book and coding form to guide the coding of the inputs. The coding categories are defined by the content of the input itself.

4. Read and code each input as to the opinions and supporting reasons they contain and enter the information on the coding form. Reliability checks of the accuracy of the coding were made continuously.

5. Assemble the opinions and supporting reasons into a set of organized tables which display the content of the public input. 
The major emphasis of the process is in the coding of individual inputs (part 4 above). This necessitated careful training of coders through discussion of the code book, joint coding, reliability checks and group discussions to ensure uniform application of the system.

This analysis system coded many variables such as form of input, residence of the respondent, number of inputs, number of signatures, etc. This information was placed on edge punch cards which make the data easily retriveable. This information is also retrievable in combinations. For example, how many inputs from Catron County objected to the concept of wilderness in general? What was the residence of the people who commented on Unit 非20-006? How many personal letters made comments on specific units?

The analysis of public comments, and resulting summary report, provide a useful tool to help decision-makers decide and aid the public in evaluating decisions made. The summary format allows the reader to efficiently identify areas of interest and pursue detailed information where needed. However, this report is not intended to replace or reduce the importance of reading of individual letters. The judgment as to the importance of information received depends heavily upon a personal knowledge gained through reading individual inputs. 
As mentioned, this report is intended to summarize the nature and extent of public comments received. Data gathered in the analysis is displayed primarily through tables, which dominate the balance of this report. This is intended to promote objective display of the data with a minimum of interpretation.

Public comments received during our comment period on WSA proposals fell into two categories:

1. Those which made general comments about wilderness, the program, the procedures, the BLM, etc.

2. Those which made comments on specific inventory units.

The balance of this report is organized into two parts based upon these two categories:

Part $I$ is a summary of all comment which did not pertain to a specific inventory unit and all demographic data and the balance of opinion on the ten most discussed unit.

Part II is devoted exclusively to displaying information which pertains directly to specific inventory units.

It must be remembered that this report is analysis of the public inputs. The weight, importance and validity of the comments received is evaluation and is not a part of this report. Evaluation is conducted by the decision-maker.

In the information that follows, numbers are presented in both Inputs (I) and Signatures (S). For example, if one person wrote three letters, the resulting tally would be $I=3$ and $S=1$. If three people signed one letter, the tally would be $I=1$ and $S=3$.

Some inputs were official positions of governments, groups, companies or organizations who represent a large constituency. These inputs were counted in the same input/signature manner. However, these inputs (letters) were also displayed separately to the decision-maker. 
PART I

Summary of Demographic Data and

Genera1 Opinion and Comments 
Tota1

3696 Inputs

5270 Signatures 
Table 1 summarizes the various means by which the public responded to the WSA recommendations. A personal letter is a letter from an individual or group while a form letter would be any letter which was mass produced for individual signatures. Three types of form letters were received during the comment period. The Las Cruces WSA Proposal recommended 43 areas and 773,000 acres in Las Cruces District for wilderness study while the Conservationist Coupon recommended 78 (or 79) areas containing 1,661,816 acres throughout New Mexico for wilderness study. The Aden Lava Flow/West Potrillos form letter opposed the designation of units NM-030-052 and 053 as Wilderness Study Areas. Two forms of verbal input were documented during the comment period. The first was any informal conversation and the second was formal testimony received at a public meeting. A few inputs were very elaborate and, in effect, were reports which presented valuable data. In addition, several petitions were received. Two comment forms were distributed for the purpose of facilitating public input. One of these was prepared by the BLM and contained a general outline to guide the discussion of an area's wilderness characteristics. The second was a "fill-in-the-blank" letter prepared by the Range Improvement Task Force which addressed an area's wilderness characteristics, along with other factors which could not be considered during this phase of the review process. 
Table 1

Type of Input

\begin{tabular}{rll}
\hline 486 & Personal Letters \\
67 & Testimonies \\
17 & Reports \\
11 & Petitions \\
13 & BLM Comment Forms \\
38 & RITF Letters \\
95 & Las Cruces WSA Proposals \\
2307 & Conservationist Coupons \\
656 & West Potrillos Form Letters \\
2 & Others
\end{tabular}

3696 Total 
Table 2 displays the group types represented by the respondents. The respondent(s) may have been an Individual representing himself or they may have been two or more family members. A formal group is a recognized organization while an informal group might be a group of friends or associates who formed primarily to author an input. A corporation is an incorporated company while a government official would be an elected or appointed official representing his office.

Table 2

Group Type of Respondent

Inputs Signatures

\begin{tabular}{rrl}
3436 & 3413 & Individual \\
121 & 241 & Family \\
26 & 1526 & Informal Group \\
56 & 41 & Formal Group \\
37 & 29 & Corporation \\
20 & 20 & Government official \\
\hline 3696 & 5270 & Total
\end{tabular}


Table 3 displays the geographic origin of inputs by state and county (New Mexico).

Table 3

Geographic Distribution of Inputs' Origin

State

Arizona

Arkansas

California

Colorado

Connecticut

Delaware

Washington, DC

Florida

Georgia

Hawaii

Idaho

Illinois

Iowa

Kentucky

Louisiana

Maine

Maryland

Massachusetts

Michigan

Mississippi

Missouri

Montana

Nebraska

New Hampshire

New Jersey

New York

North Carolina

North Dakota

Ohio

Oklahoma

Oregon

Pennyslvania

Rhode Island

South Carolina

Tennessee

Texas

Utah

Vermont

Virginia

Washington

West Virginia

Wisconsin

Wyoming

Unknown

\section{Inputs Signatures}

19

12

47

13

81

1

42

21

26

1

3

255

2

21

29

5

118

164

114

17

3

5

20

24

166

367

58

3

169

25

101

154

1

14

40

382

4

3

95

128

3

6

2

62

24

168

398

58

3

171

25

104

155

1

14

41

307

New Mexico

County

Bernalillo

Catron

Chaves

Colfax

Dona Ana

Eddy

Grant

Hidalgo

Lea

Lincoln

Los Alamos

Luna

Mora

Otero

Quay

Rio Arriba

Roosevelt

Sandoval

San Juan

Santa Fe

San Migue1

Sierra

Socorro

Taos

Valencia
Inputs Signatures

100

727

17

5

3

426

11

28

17

5

41

1

95

1

10

1

1

1

3

1

36

1

9

49

1
5
409

\section{5}

3

639

11

16

19

5

42

1

103

1

10

1


Table 4 shows the balance of opinion on the concept of wilderness in general. Reasons and comments favoring the concept of wilderness in general, as well as those opposing, were offered by members of the public. Conditional comments were those favoring wilderness under certain circumstances. Some respondents offered a general comment which could not be included in any of the other categories.

Table 4

Balance of Opinion on the Concept of Wilderness in General Inputs Signatures

\begin{tabular}{rrll}
114 & 112 & Favor \\
52 & 59 & Oppose \\
8 & 7 & Conditional \\
20 & 20 & Comments \\
\hline 194 & 198 & Total
\end{tabular}


Table 4 continued

Reasons Favoring Wilderness in General

Inputs Signatures

\begin{tabular}{|c|c|c|}
\hline 27 & 21 & $\begin{array}{l}\text { Wild lands belong to all Americans and should be } \\
\text { protected from exploitation. }\end{array}$ \\
\hline 12 & 13 & $\begin{array}{l}\text { Wilderness should be preserved for ourselves and } \\
\text { future generations. }\end{array}$ \\
\hline 7 & 1 & $\begin{array}{l}\text { To some "flat and bare is beautiful." Desert rat } \\
\text { aesthetic may not be pervasive, but it is legitimate. }\end{array}$ \\
\hline 5 & 5 & We need to preserve wilderness in America. \\
\hline 5 & 5 & Preserve as much wilderness as possible. \\
\hline 5 & 5 & Wilderness is an irreplaceable resource. \\
\hline 5 & 5 & Wilderness is needed to protect plants and wildlife. \\
\hline 2 & 3 & Wilderness offers spiritual and psychological renewal. \\
\hline 2 & 2 & Wilderness is our most valuable resource. \\
\hline 2 & 2 & Wilderness needs to be protected from destruction. \\
\hline 1 & 2 & Keep an ecological balance. \\
\hline 1 & 1 & Preserve wilderness for historic preservation. \\
\hline 1 & 1 & These areas are the heritage of all Americans. \\
\hline 1 & 1 & $\begin{array}{l}\text { Wilderness perpetuates traditional lifestyles and } \\
\text { uses of the land which is desirable. }\end{array}$ \\
\hline 1 & 1 & $\begin{array}{l}\text { Set aside wilderness on BLM lands to preserve our } \\
\text { fragile environment and reduce our oversupply of beef. }\end{array}$ \\
\hline 1 & 1 & $\begin{array}{l}\text { People, through Congress, have supported wilderness } \\
\text { as a land designation. It is not a western phenomenon, } \\
\text { but also takes place in the east. }\end{array}$ \\
\hline 1 & 1 & $\begin{array}{l}\text { Westerners do not appreciate how fortunate they are in } \\
\text { having a wealth of undeveloped areas. }\end{array}$ \\
\hline 1 & 1 & We should be proud of our New Mexico wilderness areas. \\
\hline 1 & 1 & BLM has too often been the "Bureau of Livestock and \\
\hline 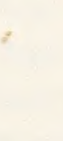 & & $\begin{array}{l}\text { Mining" when it comes to managing public lands. } \\
\text { Wilderness and wildlife has usually taken a back seat } \\
\text { to fulfilling the desires of commercial interests. }\end{array}$ \\
\hline 1 & 1 & Protect lands from development. \\
\hline 1 & 1 & Increased ecological pressures. \\
\hline 1 & 1 & $\begin{array}{l}\text { Importance of preserving lands for future study and } \\
\text { enjoyment outweigh any economic arguments for } \\
\text { exclusion. }\end{array}$ \\
\hline 2 & 1 & $\begin{array}{l}\text { Don't let development interests take our very best } \\
\text { lands. }\end{array}$ \\
\hline 1 & 1 & "I'm just plain in favor a wilderness area." \\
\hline 1 & 1 & "I support the idea and need for wilderness." \\
\hline 1 & 1 & Buffer against pollution. \\
\hline 1 & 1 & Preserve for wilderness recreation. \\
\hline 1 & 1 & There are plenty of lands available for consumptive use. \\
\hline 30 & 30 & reasons offer \\
\hline
\end{tabular}


Table 4 continued

Reasons Opposing Wilderness in General

\section{Inputs Signatures}

\begin{tabular}{|c|c|c|}
\hline L8 & 20 & $\begin{array}{l}\text { Wildernes will prevent development of energy and } \\
\text { minerals resources. }\end{array}$ \\
\hline 5 & 6 & $\begin{array}{l}\text { Wilderness will deny access to the elderly, } \\
\text { handicapped and rockhounds. }\end{array}$ \\
\hline 4 & 9 & $\begin{array}{l}\text { Wilderness discriminates against many for the } \\
\text { benefit of a few. }\end{array}$ \\
\hline 4 & 4 & $\begin{array}{l}\text { Wilderness locks out taxpayers and creates hardships, } \\
\text { for economy, ranchers and mineral exploration. }\end{array}$ \\
\hline 4 & 3 & $\begin{array}{l}\text { Land should not be taken from productive agricul- } \\
\text { tural use just to make a wilderness. }\end{array}$ \\
\hline 1 & 1 & $\begin{array}{l}\text { Wilderness will conflict with the development of } \\
\text { private minerals. }\end{array}$ \\
\hline 1 & 1 & Conflicts with flood control. \\
\hline 1 & 1 & Would interfere with use of state inholdings. \\
\hline 1 & 1 & Wilderness is not conducive to wildlife management. \\
\hline 2 & 2 & Wilderness has adverse economic impacts. \\
\hline 1 & 1 & $\begin{array}{l}\text { Wilderness visitors will eventually crowd out the } \\
\text { cowman. }\end{array}$ \\
\hline 1 & 1 & Wilderness will decrease the value of adjacent lands. \\
\hline 1 & 1 & State has enough wilderness. \\
\hline 1 & 1 & Wilderness is a waste of money. \\
\hline 1 & 1 & $\begin{array}{l}\text { Lands have been well-used without turning into } \\
\text { wilderness. }\end{array}$ \\
\hline 1 & 1 & Objects to any wilderness in New Mexico. \\
\hline 1 & 1 & $\begin{array}{l}\text { Wilderness areas are a step not into the future, but } \\
\text { a step into the past. }\end{array}$ \\
\hline 1 & 1 & Local people don't want any more wilderness. \\
\hline 1 & 1 & Wilderness would conflict with hunting. \\
\hline 4 & 4 & reasons offered. \\
\hline
\end{tabular}


Table 4 continued

Conditional Comments on Wilderness

\section{Inputs Signatures}

$2 \quad 1$

$1 \quad 1$

$1 \quad 1$

$1 \quad 1$

11

11

2

2
Wilderness is pushed through by tight knit interest groups and the vast majority of citizens could care less. ARCO favors wilderness, but not millions and millions of acres.

There is a need for wilderness providing those areas lacking wilderness characteristics be deferred for other uses.

Will oppose wilderness until grazing language is resolved to our satisfaction.

If wilderness is destroyed, we might as well stay in Texas.

The Federation approves the principle of wilderness as expressed in the Wilderness Act. We encourage critical and rigorous review of roadless areas to ensure that only lands qualifying under the Wilderness Act are designated wilderness.

Not against wilderness, but question is how much.

No supporting reasons offered. 
Table 4 Continued

Other Comments on Wilderness in General

\begin{tabular}{|c|c|c|}
\hline Inputs & Signatures & Comments \\
\hline 1 & 1 & $\begin{array}{l}\text { Not enough Congressional support for classification } \\
\text { of Forest Service lands. }\end{array}$ \\
\hline 1 & 1 & Who favors wilderness? \\
\hline 1 & 1 & $\begin{array}{l}\text { Cannot be taken for granted that land will be left } \\
\text { from other uses. }\end{array}$ \\
\hline 1 & 1 & $\begin{array}{l}\text { Foundation of Wilderness Act is to make most efficent } \\
\text { use of resources without obliterating them for the } \\
\text { future. }\end{array}$ \\
\hline 1 & 1 & What are advantages of wilderness to locals? \\
\hline 1 & 1 & Why not leave areas like they are? \\
\hline 1 & 2 & Please leave the land as it is. \\
\hline 1 & 1 & $\begin{array}{l}\text { Wild places are more difficult to protect from } \\
\text { development }\end{array}$ \\
\hline 1 & 1 & $\begin{array}{l}\text { Please do all you can to prevent New Mexico from } \\
\text { becoming another New Jersey. }\end{array}$ \\
\hline 1 & 1 & $\begin{array}{l}\text { Wilderness overuse is evidence of need and desire to } \\
\text { protect }\end{array}$ \\
\hline 2 & 1 & Wilderness does not lock up vital resources forever. \\
\hline 1 & 1 & Why do we need wilderness? There is plenty in Siberia. \\
\hline 1 & 1 & $\begin{array}{l}\text { We've still done a very poor job of educating the } \\
\text { public on what wilderness actually is. }\end{array}$ \\
\hline 1 & 1 & $\begin{array}{l}\text { Wilderness does not mean protection of the land. } \\
\text { Wilderness will limit fire control and water development. } \\
\text { Many areas will not be treated with intent of law. }\end{array}$ \\
\hline 1 & 1 & I am not against wilderness. \\
\hline 1 & 0 & $\begin{array}{l}\text { Too much of our wilderness is already lost to the chain } \\
\text { saw, bulldozer, mining, etc. }\end{array}$ \\
\hline 1 & 2 & $\begin{array}{l}\text { Want to see public lands in Luna County remain in } \\
\text { multiple use. }\end{array}$ \\
\hline 1 & 1 & $\begin{array}{l}\text { Disturbed over controversy regarding how these lands } \\
\text { will be managed if they ever become wilderness versus } \\
\text { the interim management regulations. }\end{array}$ \\
\hline 1 & 1 & $\begin{array}{l}\text { (Letter to Senator Domenici) - "You propose to reduce } \\
\text { drastically natural and wilderness areas, opening them } \\
\text { up to exploitation for private gain." }\end{array}$ \\
\hline 1 & 2 & $\begin{array}{l}\text { Devastating if unable to travel into the desert without } \\
\text { a car. }\end{array}$ \\
\hline 1 & 1 & The Wilderness Society gets a little carried away. \\
\hline
\end{tabular}


Table 5 presents the balance of opinion on the BLM's Wilderness Inventory Results. Reasons favoring and opposing the inventory results are displayed as are the conditional and general comments.

Table 5

Balance of Opinion on BLM Wilderness Inventory Results Inputs Signatures

\begin{tabular}{lll}
21 & 19 & Favor \\
43 & 48 & Oppose \\
15 & 13 & Conditional \\
12 & 12 & Comments \\
\hline 91 & 92 & Total
\end{tabular}


Table 5

Reasons Favoring Inventory Results

\section{Inputs Signatures}

$\begin{array}{ll}5 & 4 \\ 1 & 1 \\ 2 & 1 \\ 1 & 1 \\ & \\ 11 & 12\end{array}$

\section{Supporting Reasons}

Agrees with recommendations to drop specific units. Agrees with recommendation for Little Dog Canyon, Pup Canyon and Rim.

Socorro District Intensive Inventory was done in a thorough and professional manner.

Solitude is important . . New Mexico has the opportunity to save some wilderness.

No supporting reasons offered.

Reasons Opposing Inventory Results

\section{Inputs Signatures}

$\begin{array}{rr}9 & 5 \\ 10 & 7\end{array}$

23

$4 \quad 4$

$3 \quad 3$

$2 \quad 2$

$1 \quad 1$

$1 \quad 1$

12

$1 \quad 12$

$2 \quad 2$

$1 \quad 1$

4

\section{Supporting Reasons}

Several units in Las Cruces need to be reinventoried. Specific units contain roads and other intrusions which detract from naturalness.

Opposed to any Wilderness Study Areas in Luna County. Opposed to any Wilderness Study Areas.

Wilderness study will create economic hardships. Many areas do not contain 5,000 acres with wilderness characteristics.

Proposed acreage is grossly excessive.

Proposed acreage is too small.

Specific units do not have opportunities for solitude or primitive recreation.

Lands do not meet Congress' intent of wilderness.

BLM is caught up in the wilderness hysteria and the review is not scientific.

Decision is subjective and gives too much weight to anti-wilderness interests.

No supporting reasons offered. 
Table 5

Conditional Comments on Inventory Results

\begin{tabular}{|c|c|c|}
\hline Inputs & Signatures & Comments \\
\hline 3 & 3 & $\begin{array}{l}\text { Agrees with most of the recommendation, however, } \\
\text { there are few areas of contention. }\end{array}$ \\
\hline 1 & 1 & Support conditional on access to private road. \\
\hline 2 & 1 & The BLM should increase the amount of acreage protected. \\
\hline 2 & 2 & $\begin{array}{l}\text { Expresses concern over the inventory results in Las } \\
\text { Cruces. }\end{array}$ \\
\hline 2 & 1 & What is recommended is good, but inadequate. \\
\hline 1 & 2 & $\begin{array}{l}\text { Considering time, funding, personnel changes, Las Cruces } \\
\text { District personnel did a fine job. }\end{array}$ \\
\hline 2 & 2 & $\begin{array}{l}\text { Agrees with recommendations for some units and disagrees } \\
\text { for others. }\end{array}$ \\
\hline 1 & 1 & Supports most of the deleted recommendations. \\
\hline 1 & 1 & No supporting reasons offered. \\
\hline
\end{tabular}

General Comments on Inventory Results

\section{Inputs Signatures $\quad \underline{\text { Comments }}$}

$2 \quad 2$

$1 \quad 1$

$1 \quad 1$

$1 \quad 1$

$1 \quad 1$

$1 \quad 1$

$1 \quad 1$

$1 \quad 1$

$1 \quad 1$
We are opposed to the Wilderness Study Area. Compliments BLM for thorough compilation of information. Looks like an awful lot of country to take out of multiple use.

Requested printed material on Wilderness Review. Supporter of Wilderness Study Area in New Mexico. Wilderness inventories are a vital element of the National Wilderness Preservation System.

Apologies for egregious criticisms of Wilderness Review in Las Cruces District.

Apparent at public meetings that local ranchers don't want the acreage under consideration classified as wilderness.

Supports a careful review so only lands which truly qualify will become wilderness. 
Table 6 displays the balance of opinion on the methods used to involve the public during the Intensive Wilderness Inventory. Reasons favoring and opposing the public involvement methods are displayed as are the conditional and general comments.

Table 6

Balance of Opinion on Public Involvement Methods

Inputs

Signatures

\begin{tabular}{rrl}
\hline 4 & 3 & Favor \\
10 & 194 & Oppose \\
21 & 25 & Comments \\
\hline 35 & 222 & Total
\end{tabular}


Table 6

Reasons Favoring Public Involvement Methods

Inputs Signatures Supporting Reasons

43 No supporting reasons offered.

Reasons Opposing Public Involvement Methods

Inputs Signatures

$\begin{array}{rr}2 & 2 \\ 1 & 1 \\ 1 & 1 \\ 2 & 186\end{array}$

4 4

\section{Supporting Reasons}

Disregard for public comments shown.

Wants to meet person who wrote intensive inventory report.

Not enough weight given to ranchers' testimony as opposed to conservationists testimony. Was misled into believing area had already been dropped and given little time to comment. . . District Manager and Wilderness Coordinator were inconsistent when defining boundaries and ignored policy. . . Individuals not dependent on public land should not be able to dictate land use policy. No supporting reasons offered.

General Comments on Public Involvement Methods

\section{Inputs Signatures}

\section{1}

1

2

1

1

$\begin{array}{ll}1 & 1 \\ 1 & 1\end{array}$

$2 \quad 1$
1

1

\section{Comments}

Do what you can for future generations. Compliments to Dan Rathbun for fine manner in which public meetings were conducted in Las Cruces, Lordsburg and Deming.

Public comment period should be extended through December 31, 1981.

Many New Mexico ranchers favor no wilderness on BLM lands.

Deming meeting was dominated by special interest groups, ranchers, oil, etc. They don't represent the "public interest."

Requests 60 day extension to comment period.

Is first step in answering how much wilderness to preserve.

Requests extension of comment period.

Appreciates the opportunity to comment. 
Table 6

General Comments on Public Involvement Methods

\section{Inputs Signatures $\quad \underline{\text { Comments }}$}

$1 \quad 1$

1

$1 \quad 1$

1

$1 \quad 1$

1

$1 \quad 1$

1

2

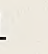

1

1

1

1

Will be greatly upset if areas recommended for deletion are returned to Wilderness Study. Requested copies of Range Improvement Task Force letters.

Thanks for coming over here so we could address comments to the boss.

Urges consideration of comments from concerned citizens.

New Mexico Department of Finance and Administration received proposals and will comment later.

Thanks for the intensive inventory information. Please send all previous documents.

Is a record of this meeting kept? What impact will it have on the decision?

Will public hearings be held for each area during the study process?

BLM says it won't count votes, but it included Floridas because of 40 letters favoring. . . Why didn't ranchers get to go along during ground work. 
Ten public meetings were held throughout the state. Table 7 summarizes the record of each meeting. Comments were categorized as either favoring or opposing wilderness study for specific units or as being general comments or questions.

Table 7

Opinions Expressed at Public Meetings

Favor WSA for Oppose WSA for General

Public Meeting

Specific Areas Specific Areas

Comments

Tota1

Las Cruces District

$\begin{array}{llrlr}\text { Alamogordo } & 1 & 1 & 4 & 6 \\ \text { Las Cruces } & 4 & 1 & 5 & 10 \\ \text { Lordsburg } & 2 & 5 & 3 & 10 \\ \text { Deming } & 0 & 12 & 7 & 19\end{array}$

Socorro District

$\begin{array}{llllr}\text { Albuquerque } & 0 & 2 & 1 & 3 \\ \text { Socorro } & 5 & 3 & 2 & 10 \\ \text { Grants } & 0 & 0 & 0 & 0\end{array}$

Roswe11 District

Roswel1 0

Carlsbad.

$\begin{array}{llll}0 & 1 & 0 & 0\end{array}$

Albuquerque District

\begin{tabular}{lllll} 
Albuquerque & 1 & 3 & 4 & 8 \\
\hline Total & 13 & 28 & 26 & 67
\end{tabular}


Table 8 reveals, by point of origin, the opinions expressed by members of the public. Inputs were classified as either inputs favoring or opposing wilderness study for specific units or groups of units, form letters and petitions favoring or opposing wilderness study for specific units or groups of units, or as containing general comments.

Table 8

Variation of Opinion by Geographic Origin

\begin{tabular}{|c|c|c|c|c|c|c|c|c|c|c|}
\hline & & zas & Ar & & $\begin{array}{r}\text { Eas } \\
\text { United }\end{array}$ & $\begin{array}{l}\text { Lern } \\
\text { States }\end{array}$ & $\begin{array}{l}\text { W } \\
\text { Unit }\end{array}$ & $\begin{array}{l}\text { ern } \\
\text { States }\end{array}$ & New & Mexico \\
\hline & $\mathrm{I}$ & $S$ & $\bar{I}$ & $\mathrm{~S}$ & $I$ & $\mathrm{~S}$ & $I$ & $S$ & I & $\mathrm{S}$ \\
\hline Favor WSA for & & & & & & & & & & \\
\hline Specific Areas & 11 & 12 & 1 & 1 & 4 & 2 & 3 & 3 & 120 & 121 \\
\hline Oppose WSA for & & & & & & & & & & \\
\hline Specific Areas & 12 & 12 & 7 & 6 & 1 & 1 & 10 & 10 & 176 & 175 \\
\hline $\begin{array}{l}\text { Form Letters } \\
\text { and Petitions }\end{array}$ & & & & & & & & & & \\
\hline Favoring WSA* & 232 & 232 & 2 & 2 & 1977 & 2083 & 233 & 239 & 46 & 675 \\
\hline Form Letters & & & & & & & & & & \\
\hline $\begin{array}{l}\text { and Petitions } \\
\text { Opposing WSA }\end{array}$ & 122 & 137 & 5 & 5 & 14 & 17 & 16 & 18 & 470 & 1275 \\
\hline General & & & & & & & & & & \\
\hline Comments & 3 & 3 & 6 & 6 & 4 & 4 & 8 & 7 & 59 & 58 \\
\hline Total & 380 & 396 & 21 & 20 & 2000 & 2107 & 270 & 377 & 871 & 2304 \\
\hline
\end{tabular}

*This includes personal letters endorsing the New Mexico Conservationists Wilderness Study Area Proposal. 
Table 9

Table 9 summarizes the opinions expressed on the ten most frequently discussed units. Inputs were classified as either personal inputs favoring or opposing Wilderness Study or form letters and petitions favoring or opposing Wilderness Study.

The purpose of this table is to display which inventory units generated the greatest response from the public. Decisions were not based on the total number of inputs and/or signatures favoring or opposing Wilderness Study. Instead the BLM was more concerned with the quality of the inputs and their usefulness in evaluating an area's wilderness characteristics.

For a more detailed summary of the comments addressing each unit's wilderness characteristics, refer to the appropriate unit number in part two:

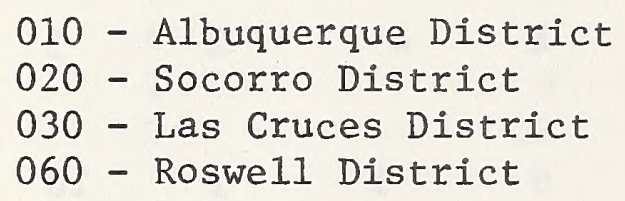


Table 9

Ten Most Discussed Units

\begin{tabular}{|c|c|c|c|c|}
\hline & $\begin{array}{c}\text { Persona1 Inputs } \\
\text { Favoring WSA }\end{array}$ & $\begin{array}{c}\text { Personal Inputs } \\
\text { Opposing WSA }\end{array}$ & $\begin{array}{l}\text { Form Letters } \\
\text { and Petitions } \\
\text { Favoring WSA }\end{array}$ & $\begin{array}{l}\text { Form Letters } \\
\text { and Petitions } \\
\text { Opposing WSA }\end{array}$ \\
\hline & $\mathrm{S}$ & I & S & $\begin{array}{lll}I & S\end{array}$ \\
\hline $\begin{array}{l}\text { NM-030-034 } \\
\text { Florida }\end{array}$ & 58 & 41 & 2620 & - \\
\hline
\end{tabular}

Personal inputs favoring Wilderness Study supported this unit primarily because of its supplemental values and outstanding opportunities for solitude and primitive types of recreation; several failed to provide any supporting reasons. Several inputs opposed Wilderness Study status due to lack of apparent naturalness resulting from past mining activities and due to potential conflicts with future mining and grazing.

\begin{tabular}{lcccccccc} 
& $\begin{array}{c}\text { Personal } \\
\text { Favoring WSA }\end{array}$ & $\begin{array}{c}\text { Personal } \\
\text { Opposing WSA }\end{array}$ & $\begin{array}{l}\text { Form Letters } \\
\text { and Petitions }\end{array}$ & $\begin{array}{l}\text { Form Letters } \\
\text { and Petitions }\end{array}$ \\
\hline I & S & I & S & I & S & I & S \\
$\begin{array}{l}\text { NM-030-031 } \\
\text { Cooke's Range }\end{array}$ & 34 & 33 & 37 & 37 & 2620 & 3370 & - & -
\end{tabular}

Personal inputs favoring wilderness study for this unit supported it primarily because of its supplemental values and outstanding opportunities for solitude and primitive types of recreation. Almost half of those opposing Wilderness Study cited resource conflicts and several others discussed impacts resulting from rangeland management activities. Several individuals of both persuasions failed to provide supporting reasons for their opinions. 


\begin{tabular}{|c|c|c|c|c|}
\hline & $\begin{array}{c}\text { Personal Inputs } \\
\text { Favoring WSA }\end{array}$ & $\begin{array}{c}\text { Personal Inputs } \\
\text { Opposing WSA }\end{array}$ & $\begin{array}{l}\text { Form Letters } \\
\text { and Petitions } \\
\text { Favoring WSA }\end{array}$ & $\begin{array}{l}\text { Form Letters } \\
\text { and Petitions } \\
\text { Opposing WSA }\end{array}$ \\
\hline & $S$ & $\bar{S}$ & $S$ & $S$ \\
\hline $\begin{array}{l}\text { NM-030-052 } \\
\text { West Potrillos } \\
\text { Mountains }\end{array}$ & 31 & 31 & 2620 & 903 \\
\hline
\end{tabular}

Personal inputs supported Wilderness Study for this unit primarily because of its supplemental values and outstanding opportunities for solitude and primitive types of recreation. Half of those personal inputs opposing Wilderness Study cited resource conflicts as their principle reason. Several others did not provide any supporting reaons for their opinions.

\begin{tabular}{|c|c|c|c|c|}
\hline & $\begin{array}{c}\text { Personal Inputs } \\
\text { Favoring WSA }\end{array}$ & $\begin{array}{c}\text { Personal Inputs } \\
\text { Opposing WSA }\end{array}$ & $\begin{array}{l}\text { Form Letters } \\
\text { and Petitions } \\
\text { Favoring WSA }\end{array}$ & $\begin{array}{l}\text { Form Letters } \\
\text { and Petitions } \\
\text { Opposing WSA } \\
\end{array}$ \\
\hline & $\mathrm{S}$ & $S$ & $S$ & $I$ \\
\hline $\mathrm{NM}-020-038$ & 46 & 30 & 3724 & 185 \\
\hline & \multicolumn{4}{|c|}{$\begin{array}{l}\text { Most of the personal inputs favoring Wilderness Study supported } \\
\text { this unit because of its natural appearance and its out- } \\
\text { standing opportunities for solitude and primitive types of } \\
\text { recreation. Individuals opposing Wilderness Study argued } \\
\text { that the area is severely impacted by range improvements } \\
\text { and lacks both supplemental values and outstanding } \\
\text { opportunities for solitude and primitive types of recreation. }\end{array}$} \\
\hline
\end{tabular}


Table 9 continued

\begin{tabular}{lcccccccc} 
& $\begin{array}{c}\text { Personal } \\
\text { Favoring WSA }\end{array}$ & $\begin{array}{c}\text { Inputs } \\
\text { Opposing WSA }\end{array}$ & $\begin{array}{c}\text { Form Letters } \\
\text { and Petitions } \\
\text { Favoring WSA }\end{array}$ & $\begin{array}{c}\text { Form Letters } \\
\text { and Petitions } \\
\text { Opposing WSA }\end{array}$ \\
\hline & I & S & I & S & I & S & I & S \\
$\begin{array}{l}\text { NM-030-053 } \\
\text { Aden Lava Flow }\end{array}$ & 22 & 23 & 28 & 25 & 2620 & 3670 & 654 & 903
\end{tabular}

Half of the personal inputs favoring Wilderness Study did not provide any supporting reasons. The remainder discussed the unit's outstanding opportunities for solitude and primitive types of recreation. Resource conflicts were cited most often by those opposing wilderness study; several inputs did not provide supporting reasons.

\begin{tabular}{|c|c|c|c|c|c|c|}
\hline & $\begin{array}{c}\text { Personal Inputs } \\
\text { Favoring WSA }\end{array}$ & $\begin{array}{c}\text { Personal Inputs } \\
\text { Opposing WSA }\end{array}$ & $\begin{array}{l}\text { Form Let } \\
\text { and Peti } \\
\text { Favoring }\end{array}$ & $\begin{array}{l}\text { ters } \\
\text { tions } \\
\text { WSA }\end{array}$ & $\begin{array}{l}\text { Form Lett } \\
\text { and Petit } \\
\text { Opposing }\end{array}$ & $\begin{array}{l}\text { ters } \\
\text { tions } \\
\text { WSA } \\
\end{array}$ \\
\hline & $I$ & $\mathrm{~S}$ & $I$ & $S$ & $I$ & $S$ \\
\hline $\begin{array}{l}\text { NM-030-035 } \\
\text { Big Hatchet } \\
\text { Mountains }\end{array}$ & 31 & 13 & 2620 & 3370 & - & - \\
\hline
\end{tabular}

Personal inputs favoring wilderness study supported this unit primarily because of its supplemental values and outstanding opportunities for solitude and primitive types of recreation. Inputs opposing Wilderness Study dealt primarily with resource conflicts and impacts resulting from mining and rangeland management activities. 
Table 9 continued

\begin{tabular}{llccccccc} 
& $\begin{array}{c}\text { Personal } \\
\text { Favoring WSA }\end{array}$ & $\begin{array}{c}\text { Inputs } \\
\text { Opposing WSA }\end{array}$ & $\begin{array}{c}\text { Form Letters } \\
\text { and Petitions } \\
\text { Favoring WSA }\end{array}$ & $\begin{array}{c}\text { Form Letters } \\
\text { and Petitions } \\
\text { Opposing WSA }\end{array}$ \\
\hline & I & S & I & S & I & S & I & S \\
$\begin{array}{l}\text { NM-030-042 } \\
\text { Cedar Mountains }\end{array}$ & 11 & 12 & 31 & 31 & 2619 & 2755 & - & -
\end{tabular}

Most of the personal inputs favoring Wilderness Study status stated that the unit offers outstanding opportunities for solitude and primitive types of recreation. Inputs opposing Wilderness Study primarily cited resource conflicts and impacts resulting from rangeland management activities. Four inputs requested a reinventory of the unit.

\begin{tabular}{|c|c|c|c|c|c|c|c|c|}
\hline & $\begin{array}{c}\text { Personal } \\
\text { Favoring }\end{array}$ & $\begin{array}{l}\text { Inputs } \\
\mathrm{g} \text { WSA }\end{array}$ & $\begin{array}{r}\text { Personal } \\
\text { Opposing }\end{array}$ & $\begin{array}{l}\text { Inputs } \\
\mathrm{g} \text { WSA }\end{array}$ & $\begin{array}{l}\text { Form Let } \\
\text { and Peti } \\
\text { Favoring }\end{array}$ & $\begin{array}{l}\text { ters } \\
\text { itions } \\
\text { WSA }\end{array}$ & $\begin{array}{l}\text { Form Let } \\
\text { and Peti } \\
\text { Opposing }\end{array}$ & $\begin{array}{l}\text { ters } \\
\text { tions } \\
\text { WSA } \\
\end{array}$ \\
\hline & $I$ & $\mathrm{~S}$ & $I$ & $S$ & $I$ & $S$ & $I$ & S \\
\hline $\begin{array}{l}\text { NM-030-023 } \\
\text { Gila Box }\end{array}$ & 34 & 35 & 5 & 5 & 2620 & 3370 & - & - \\
\hline
\end{tabular}

Personal inputs favoring Wilderness Study status supported this unit primarily because of its outstanding opportunities for solitude and primitive types of recreation and its unique supplemental values. Individuals opposing Wilderness Study offered a variety of supporting reasons, but no one reason was dominant. 
Table 9 continued

\begin{tabular}{|c|c|c|c|c|c|c|c|}
\hline & $\begin{array}{r}\text { Personal I } \\
\text { Favoring }\end{array}$ & $\begin{array}{l}\text { nputs } \\
\text { WSA }\end{array}$ & $\begin{array}{r}\text { Personal I } \\
\text { Opposing }\end{array}$ & $\begin{array}{l}\text { Inputs } \\
\text { g WSA }\end{array}$ & $\begin{array}{l}\text { Form Let } \\
\text { and Peti } \\
\text { Favoring }\end{array}$ & $\begin{array}{l}\text { ters } \\
\text { itions } \\
\text { WSA }\end{array}$ & $\begin{array}{l}\text { Form Letters } \\
\text { and Petitions } \\
\text { Opposing WSA }\end{array}$ \\
\hline & I & $\mathrm{S}$ & $I$ & $\mathrm{~S}$ & $I$ & $\mathrm{~S}$ & $\begin{array}{ll}\mathrm{I} & \mathrm{S}\end{array}$ \\
\hline $\begin{array}{l}\text { NM-020-016 } \\
\text { Sierra Ladrones }\end{array}$ & 33 & 31 & 4 & 4 & 2525 & 3274 & - \\
\hline
\end{tabular}

Most of the personal inputs favoring Wilderness Study status stated that the area appears to be natural, offers outstanding opportunities for solitude and primitive types of recreation and contains supplemental values; several failed to provide supporting reasons, but no one reason was dominant.

30

46

Form Letter

Form Letters

Personal Inputs Personal Inputs and Petitions and Petitions Favoring WSA Opposing WSA Favoring WSA Opposing WSA

$\begin{aligned} & \text { NM-020-044/45 } \\ & \text { Continental }\end{aligned}$
Divide

Most of the personal inputs favoring Wilderness Study status stated that the unit appears to be natural, offers outstanding opportunities for solitude and primitive recreation and contains supplemental values; several failed to provide supporting reasons. Most of those opposing Wilderness Study discussed impacts resulting from rangeland management activities. 
Table 10

Other Issues Discussed

Inputs Signatures

$\begin{array}{lcl}13 & 11 & \text { Interim Management } \\ 19 & 421 & \text { Management } \\ 12 & 404 & \text { Study } \\ 40 & 41 & \text { Resource Conflicts } \\ 21 & 19 & \text { Inventory Procedures } \\ 21 & 30 & \text { Miscellaneous Comments }\end{array}$

Following is a summary of the comments which pertain to the above categories.

Comments on Wilderness Study

\section{Inputs Signatures Comments}

\begin{tabular}{|c|c|c|}
\hline 2 & 1 & Consider minerals during the study phase. \\
\hline 2 & 2 & There is enough wilderness. \\
\hline 1 & 6 & Extremely high cost of studies. \\
\hline$\perp$ & 398 & There is enough wilderness in Catron County. \\
\hline & 1 & $\begin{array}{l}\text { Will public hearings be held for each area during } \\
\text { the study process? }\end{array}$ \\
\hline & 1 & $\begin{array}{l}\text { Fairly extensive mineral surveys will take place } \\
\text { during Wilderness Study. }\end{array}$ \\
\hline & 1 & Will natural boundaries be used? \\
\hline 1 & 1 & We are not too concerned about the study program. \\
\hline & 1 & $\begin{array}{l}\text { How much wilderness should there be? Would other } \\
\text { designations be more appropriate ? How will abuses } \\
\text { of the Wilderness Act affect existing areas? }\end{array}$ \\
\hline & 1 & $\begin{array}{l}\text { In time of rising fuel costs, areas near communities } \\
\text { are needed. }\end{array}$ \\
\hline & 1 & es be used? \\
\hline
\end{tabular}


Table 10 continued

Comments on Interim Management

\section{Inputs Signatures}

2

$\begin{array}{ll}2 & 1 \\ 1 & 1 \\ 1 & 1\end{array}$

11

11

$1 \quad 1$

$1 \quad 1$

$1 \quad 1$

$1 \quad 1$

\section{Comments}

Concerned about illegal trespasses and environmental damage.

No oil and gas leasing should take place.

Wilderness Study has no right over private minerals.

Please see that interim management protects the study areas.

Supports interim management regulations which allows ranchers access to and maintenance of range facilities. Water improvements for cattle and wildlife are needed and should be allowed.

State and private inholdings in Wilderness Study areas has not been adequately addressed.

Will stop land exchange beneficial to both BLM and allottee.

Feel grazing allotments will be affected.

Concerned about management of wildlife.

Comments on Wilderness Management

$\underline{\text { Inputs }}$ Signatures

2

2

1

1

1

1

1

1

1

1

1

1

1

1

1

1

1
2

2

398

1

1

1

1

1

1

1

1

1

1

1

1

1

1

Comments

Comments about grazing language in the Colorado Wilderness Bill.

Al1 Americans share in the management of wilderness.

Fears private lands will be condemned.

How will areas with preexisting ways be managed to keep vehicles out?

Wilderness areas should not have parking places and bathrooms.

How will wilderness areas be administered?

Eventually cattle will be removed from wilderness. How will boundaries be marked?

Areas should not be placed "off limits" to hikers and horseback riders.

Inholdings should be acquired.

How will birdwatchers get in to look for birds?

Will BLM compensate for the taking of mining claims

and range improvements?

How will hunting be managed?

Decisions are often made on short-term planning. Wilderness management has an extremely high cost. How will regulations be enforced?

Will roads within these areas be abandoned? 


\section{Inputs Signatures}

\begin{tabular}{|c|}
\hline \\
\hline $\begin{array}{l}4 \\
3\end{array}$ \\
\hline 2 \\
\hline 2 \\
\hline 2 \\
\hline 2 \\
\hline 1 \\
\hline 1 \\
\hline 1 \\
\hline 1 \\
\hline 1 \\
\hline 1 \\
\hline 1 \\
\hline \\
\hline
\end{tabular}

\section{Comments}

Inventory team missed roads. Disagrees with cherry stemming. Evaluations of outstanding opportunities must be absolute and not comparisons to other areas in a district or state.

Intensive inventory reports for some areas were only made available recently (June 1, 1980). Road versus ways identification is a problem. What criteria are being used in the selection of study areas?

Doubts that the BLM recommendations meet the requirements of the National Environmental Policy Act.

Resource conflicts cannot be considered at this stage.

BLM should inventory lands adjacent to Forest Service roadless areas.

Inventory team used a helicopter since the area is difficult to walk in.

Need to assign better inventory criteria; process considers roadless areas first instead of wilderness quality.

Was under impression that once an area had been thrown out, it could not be reentered for study.

We urge you to exercise great caution in eliminating areas for reasons which more properly ought to be considered in the study phase of the review. Concerned that BLM lands with wilderness values be studied properly.

Do not eliminate opportunities for more careful study. 
Table 10 continued

Miscellaneous Comments

Inputs Signatures

3

2

1

1

1

1

1

1

1

1

$1 \quad 1$

$1 \quad 1$

$1 \quad 1$

$1 \quad 1$

$1 \quad 1$

$1 \quad 1$

$1 \quad 1$

11

$1 \quad 1$

11

\section{Comments}

Comments on environmental analysis for oil and gas leasing in the Alamo Hueco and Big Hatchet Mountains. A few bureaucrats are dictating policy. There's too much government subsidy going on. Taxpayers are not being considered in these deliberations. Need to develop alternative energy sources. Most BLM land is not overgrazed. We are very dependent on foreign minerals. Has visited the beautiful state and feel strongly about protection.

The government is for the people, by the people and of the people. We the people are the government and don't forget it! We own that land. Western states are victims of bureaucracy and this adds fuel to the Sagebrush Rebellion.

Need to protect the maximum amount of land to prevent short sighted planning of the Foley Bill.

Mining Law of 1872 is obsolete.

Concerned about overgrazing on BLM land in Catron County.

Mining plan for Barite of America Mine in Florida Mountains.

Hope to live in New Mexico some day and see it remain wild.

The beauty of nature should not be destroyed by greed. Give attention to mineral resources when developing the district management plan.

Most state land is not allocated for multiple use. Spends recreational time in New Mexico.

Bureaucrats and alphabet agencies are out to wreck the U. S. economy.

A very small percentage of our total oil supply originates from southwestern New Mexico . . . helium is being wasted . . there are several advantages to keeping these resources in the ground as stockpiles. 
PART II

Summary of Unit Specific Comments 
Each unit summary sheet, which follows, is divided in half. The left half displays data favoring WSA status and the right half displays data opposing WSA status.

The top of each summary sheet contains the total number of inputs and signatures, favoring or opposing Wilderness Study for the unit. The number of inputs and signatures may not always correspond since one individual may have commented on a particular unit more than once or more than one individual may have authored an input. A variety of reaons were offered in support of individual recommendations, with some being cited more often than others. However, a few inputs simply expressed opposition to or support for Wilderness Study, but did not provide any supporting reasons. Below the list of supporting reasons was a separate category for any letters or petitions received. Sequence numbers referring to each input favoring or opposing wilderness study were included at the bottom of their respective columns.

A few inputs did not express opposition to or support for wilderness study, but offered general comments instead. These general comments were summarized at the bottom of the summary sheet.

Once again, it should be emphasized that the Wilderness Study decision is based upon the information provided by the inputs and not the quantity of inputs and/or signatures favoring or opposing Wilderness Study. Where necessary, unit specific comments were field-checked to verify their accuracy.

The Wilderness Study decision is based upon a determination of whether or not a unit has wilderness characteristics as defined in the BLM's Wilderness Inventory Handbook. A number of inputs supported their opinions with reasons which did not address wilderness characteristics and, therefore, cannot be considered in the final Wilderness Study decision (e.g., "wilderness is important for future generations" or "wilderness will adversely impact mining"). However, these comments were recorded and will be retained for use during subsequent phases of the wilderness review process. 



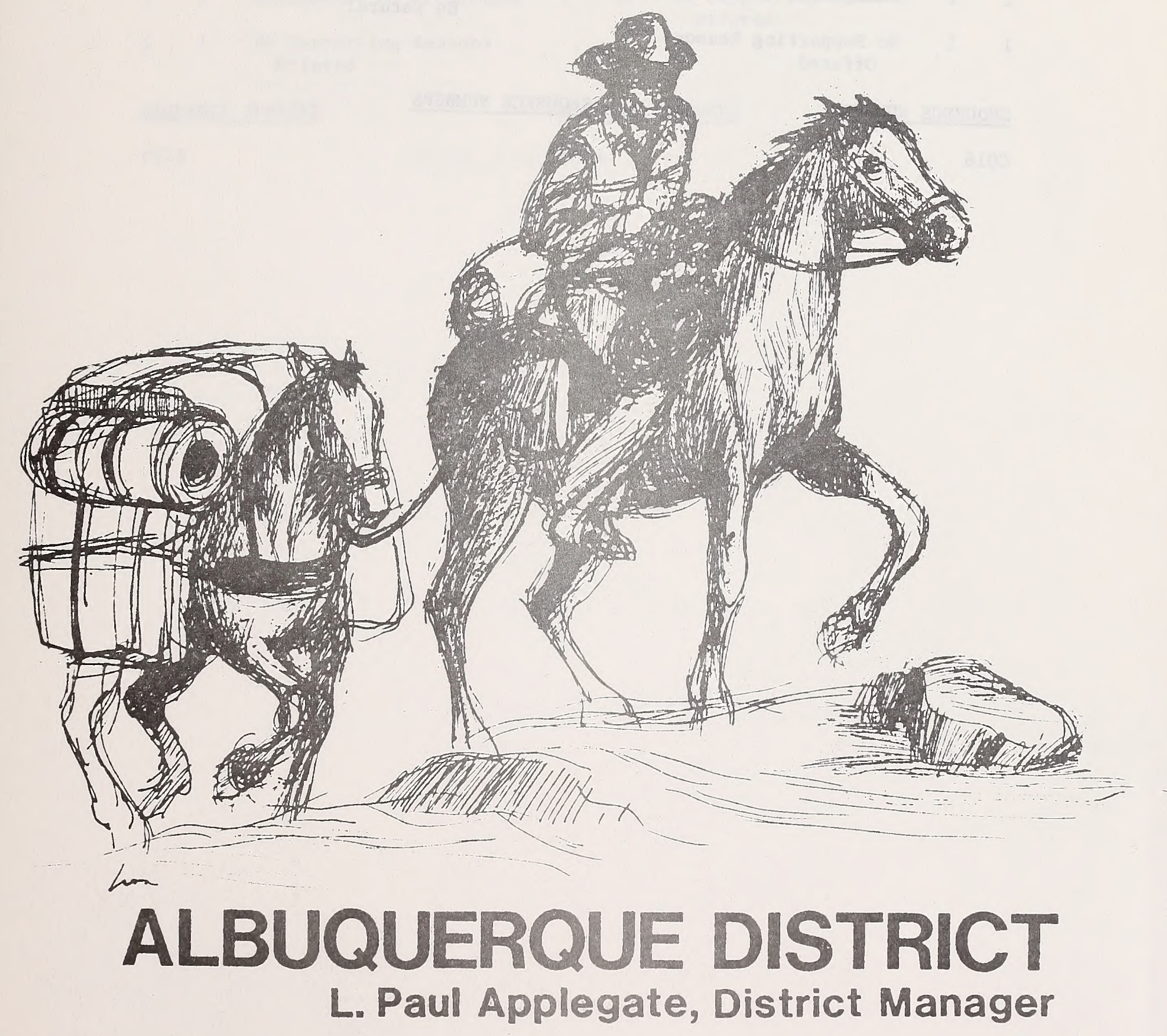




livVo
Wilderness Study
Wilderness Designation or
Wilderness Study Status

I S

11

I S

$\begin{array}{ccc}\text { I } & \text { S } & \text { Supporting Reasons } \\ 1 & 1 & \text { Manageable as Wildernes } \\ 1 & 1 & \begin{array}{c}\text { No Supporting Reasons } \\ \text { Offered }\end{array}\end{array}$

SEQUENCE NUMBERS

\section{SEQUENCE NUMBERS}

C016

G011 

Unit Number:
NM-010-9
Unit Name:
Ah-shi-sle-pah

FAVOR

Wilderness Study

I S

11

I S S Supporting Reasons

11 Manageable as Wilderness

11 No Supporting Reasons offered

SEQUENCE NUMBERS

C016
OPPOSl?

Wilderness lesignation or

Wilderness Study Status

I S

16
I S Supporting Reasons

16 No Supporting Reasons offered

SEQUENCE NUMBERS

G011 


\section{Unit Number: NM-010-012/13 Unit Name: San Ysidro}

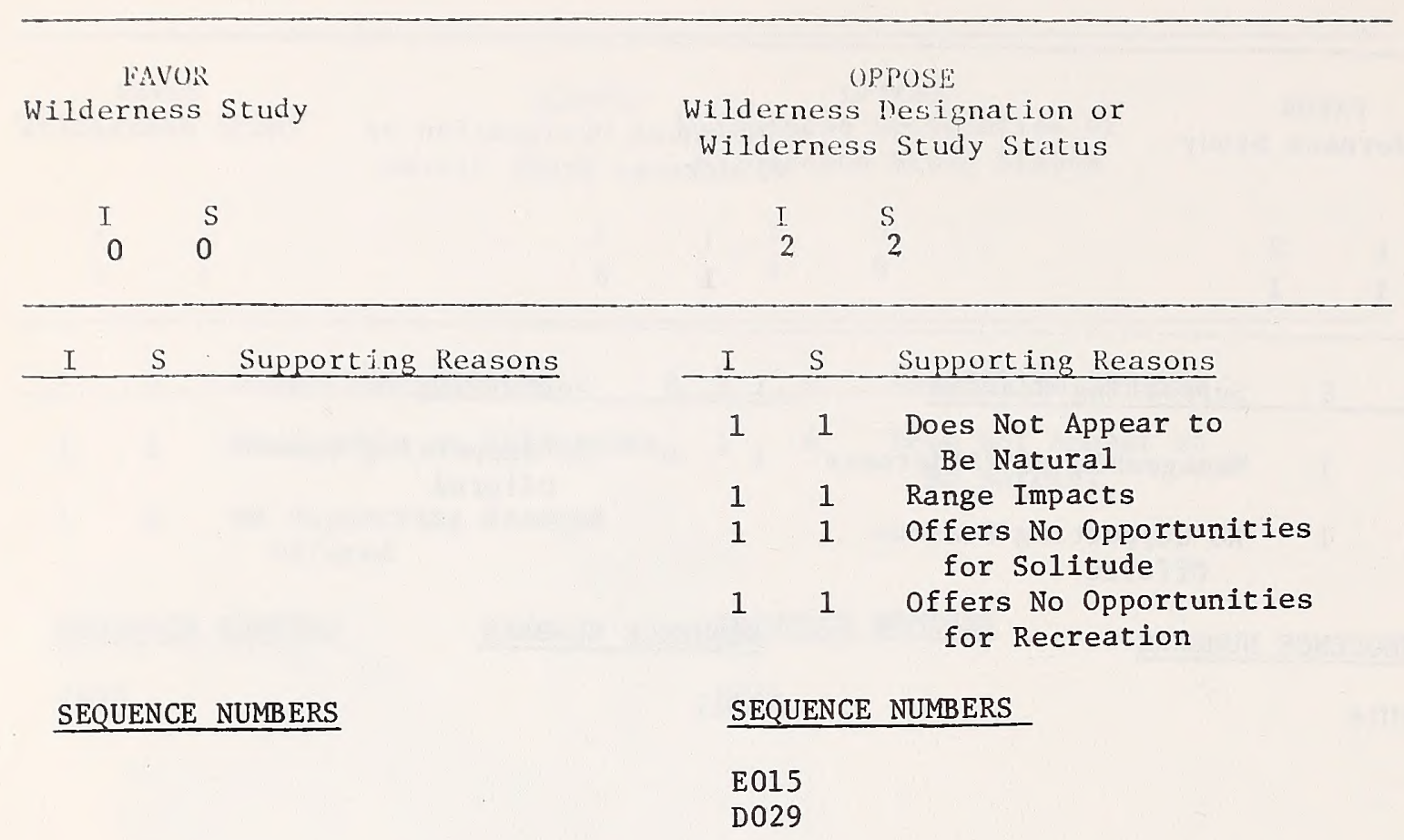




Unit Number: NM-010-15 Unit Name: Chijuilla

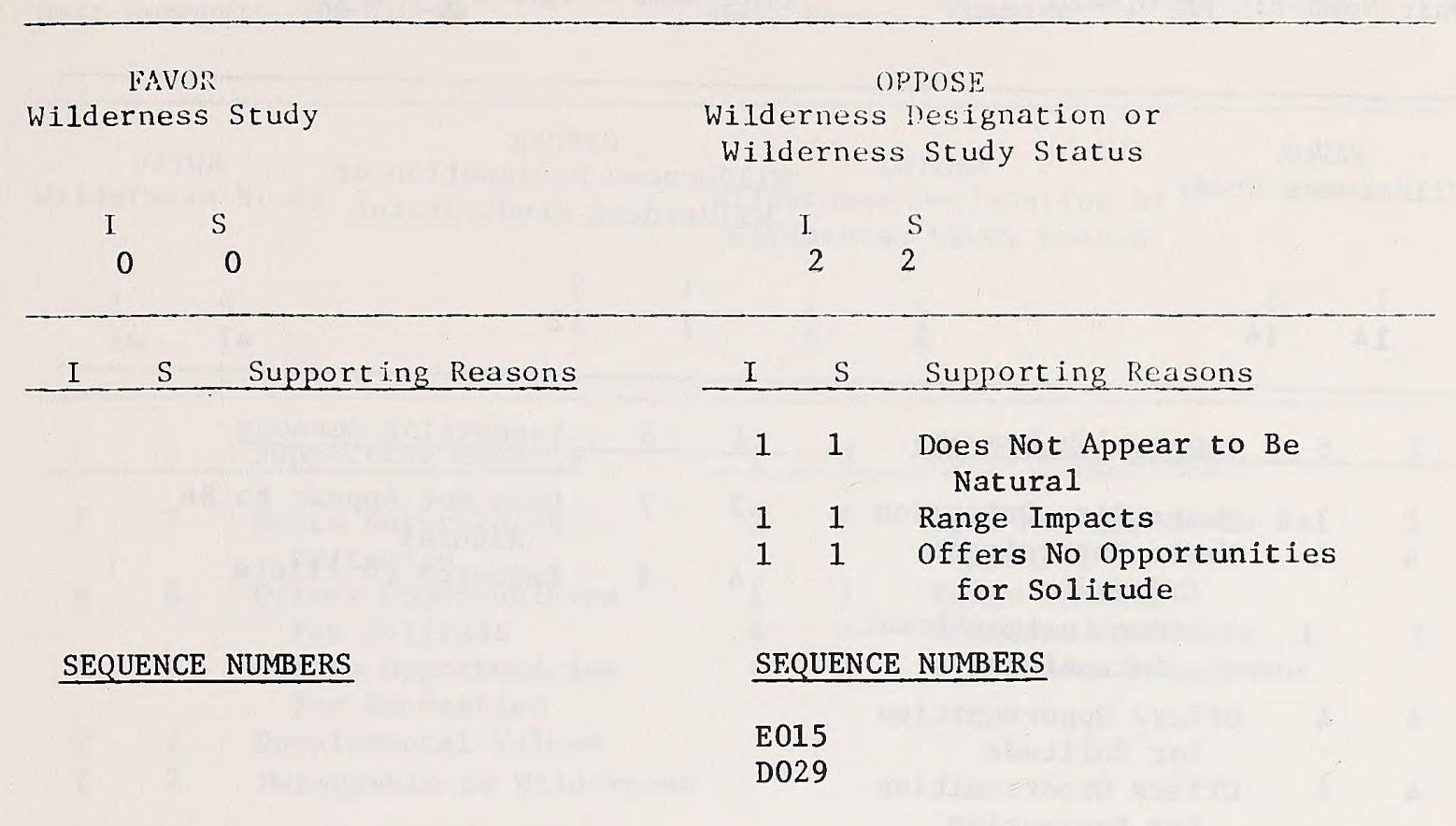


FAVOR

Wilderness Study

I S

$14 \quad 14$

\section{OPPOSF}

Wilderness lesignation or

Wilderness Study Status

I S

\begin{tabular}{|c|c|c|}
\hline I & $\underline{S}$ & Supporting Reasons \\
\hline 1 & 1 & Meets Size Criterion \\
\hline 4 & 4 & $\begin{array}{l}\text { Meets Naturalness } \\
\text { Criterion }\end{array}$ \\
\hline 1 & 1 & $\begin{array}{l}\text { Other Insignificant } \\
\text { Intrusions }\end{array}$ \\
\hline 4 & 4 & $\begin{array}{l}\text { Offers Opportunities } \\
\text { for Solitude }\end{array}$ \\
\hline 4 & 4 & $\begin{array}{l}\text { Offers Opportunities } \\
\text { for Recreation }\end{array}$ \\
\hline 2 & 2 & Supplemental Values \\
\hline 1 & 1 & Manageable as Wilderne \\
\hline 7 & 7 & $\begin{array}{l}\text { No Supporting Reasons } \\
\text { Offered }\end{array}$ \\
\hline$\underline{I}$ & $\mathrm{~S}$ & FORM LETTERS \& PETITIOI \\
\hline 2524 & 2659 & $\begin{array}{l}\text { Endorsements of Conser- } \\
\text { vationist Proposal }\end{array}$ \\
\hline 1 & 615 & $\begin{array}{l}\text { Petition Endorsing Con- } \\
\text { servationist Proposal }\end{array}$ \\
\hline
\end{tabular}

SEQUENCE NUMBERS

$\begin{array}{ll}\text { C015 } & \text { K017 } \\ \text { C016 } & \text { L020 } \\ \text { K018 } & \text { L033 } \\ \text { F014 } & \text { H028 } \\ \text { B029 } & \text { S035 } \\ \text { L022 } & \text { D010 } \\ \text { L003 } & \text { S047 } \\ \text { C030 } & \end{array}$

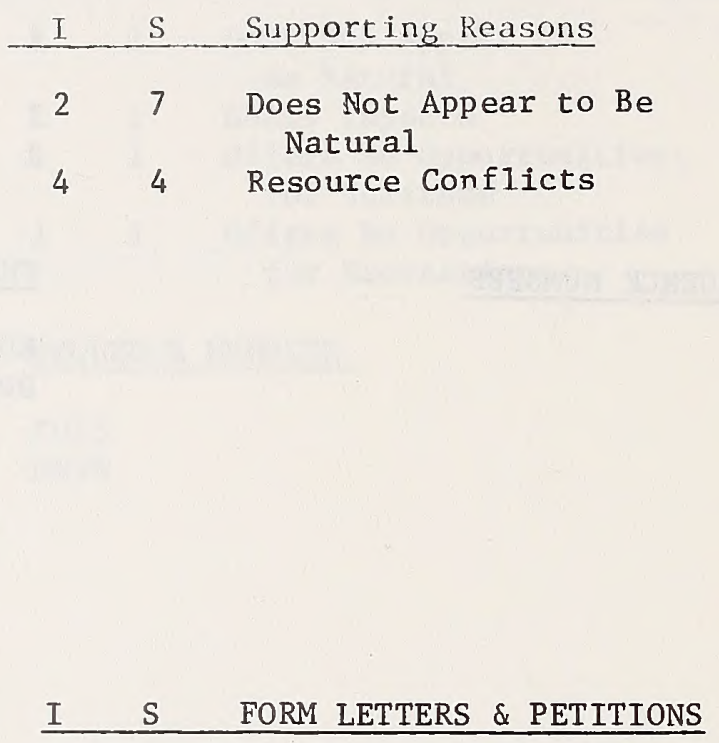

SEQUENCE NUMBERS
G025
G011
Y004
D030
D031
D029
0001 
FAVOR

Wilderness Study

\section{OPPOSE}

Wilderness !esignation or Wilderness Study Status

I $\quad$ S

$\begin{array}{ll}I & S \\ 6 & 6\end{array}$

\begin{tabular}{|c|c|c|}
\hline I & $\mathrm{S}$ & Supporting Reasons \\
\hline 7 & 7 & $\begin{array}{l}\text { Meets Naturalness } \\
\text { Criterion }\end{array}$ \\
\hline 6 & 6 & $\begin{array}{l}\text { Offers Opportunities } \\
\text { for Solitude }\end{array}$ \\
\hline 6 & 6 & $\begin{array}{l}\text { Offers Opportunities } \\
\text { for Recreation }\end{array}$ \\
\hline 2 & 2 & Supplemental Values \\
\hline 2 & 2 & Manageable as Wildernes \\
\hline 7 & 7 & $\begin{array}{l}\text { No Supporting Reasons } \\
\text { offered }\end{array}$ \\
\hline I & S & FORM LETTERS \& PETITION \\
\hline 2524 & 2659 & $\begin{array}{l}\text { Endorsements of Conser- } \\
\text { vationist Proposal }\end{array}$ \\
\hline 1 & 615 & $\begin{array}{l}\text { Petition Endorsing Con- } \\
\text { servationist Proposal }\end{array}$ \\
\hline
\end{tabular}

\section{SEQUENCE NUMBERS}

$\begin{array}{ccc}\text { I } & \text { S } & \text { Supporting Reasons } \\ 2 & 2 & \begin{array}{c}\text { Does Not Appear to Be } \\ \text { Natural }\end{array} \\ 1 & 1 & \begin{array}{l}\text { Range Impacts } \\ 4\end{array} \\ 4 & 4 & \text { Resource Conflicts } \\ \text { Wilderness Management }\end{array}$

$\begin{array}{ll}\text { G015 } & \text { K017 } \\ \text { G016 } & \text { L020 } \\ \text { K018 } & \text { W033 } \\ \text { F014 } & \text { H028 } \\ \text { L022 } & \text { S035 } \\ \text { Z000 } & \text { D010 } \\ \text { C030 } & \text { S047 } \\ \text { O001 } & \end{array}$

\section{SEQUENCE NUMBERS}

G035

C011

Y004

D030

D031

D029 


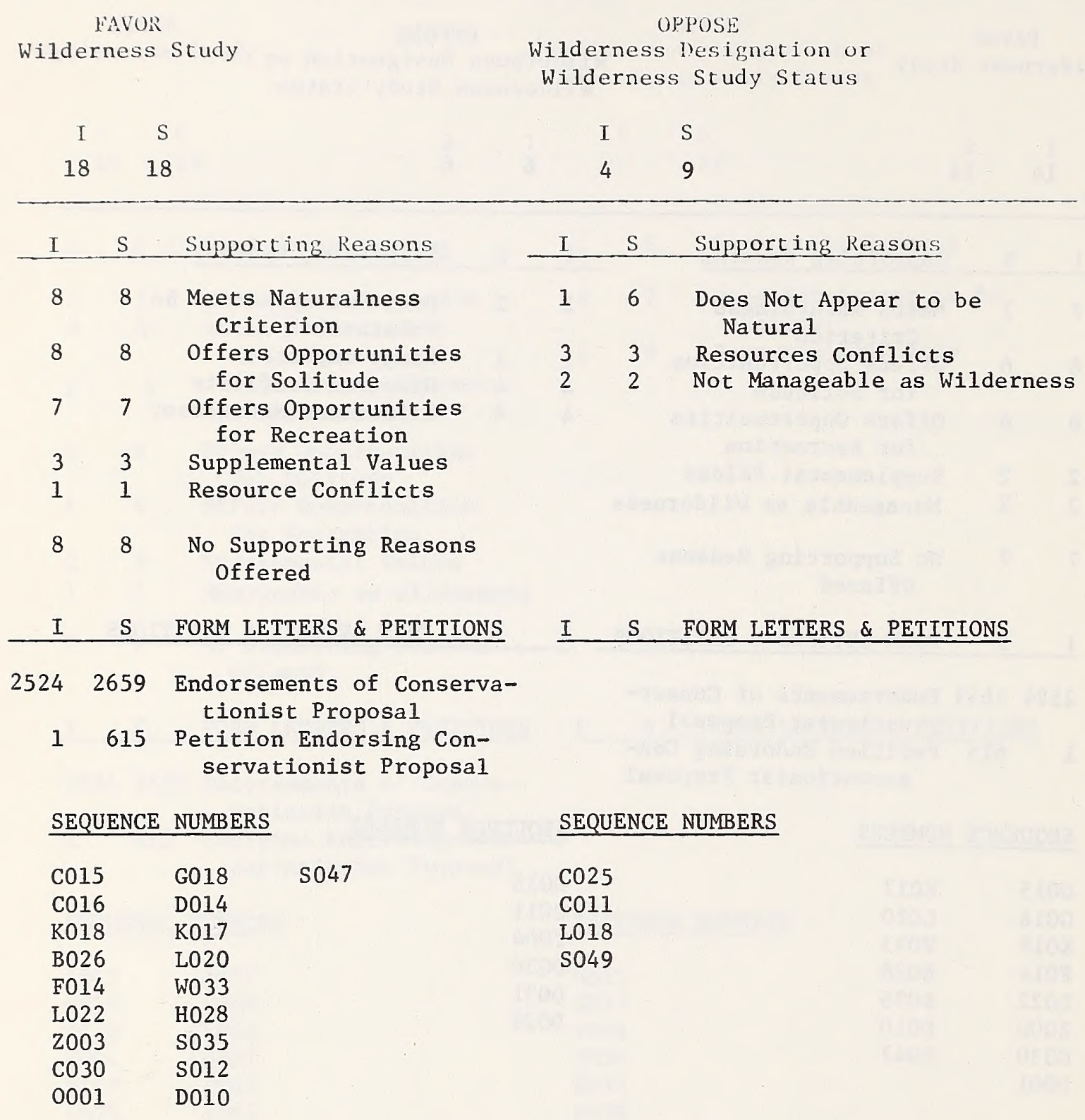


FAVOR

Wilderness Study

I S

2928
OPPOSE

Wilderness lesignation or

Wilderness Study Status

$$
\text { I }
$$

I S Supporting Reasons

11 Meets Size Criterion

11 Over 5,000 Acres

11 Sufficient Size to be

1716 Meets Naturalness

$$
\text { Criterion }
$$

31 Insignificant Mining Impacts

1817 offers Opportunities for Solitude

1514 offers Opportunities for Recreation

1514 Supplemental Values

97 Manageable as Wilderness

99 No Supporting Reasons offered

I S FORM LETTERS \& PETITIONS

\section{S Supporting Reasons}

38 Does Not Appear to be Natura1

11 Range Impacts

11 Offers No Opportunities for Solitude

11 Offers No Opportunities for Recreation

$1 \quad 1 \quad$ No Supporting Reasons offered

I S FORM LETTERS \& PETITIONS

\section{Endorsements of Conser- vationist Proposal \\ 1615 Petition Endorsing Con- servationist Proposal}

\section{SEQUENCE NUMBERS}

SEQUENCE NUMBERS

$\begin{array}{ll}\text { C006 } & \text { R014 } \\ \text { C007 } & \text { L022 } \\ \text { C005 } & \text { L012 } \\ \text { C015 } & \text { E007 } \\ \text { C008 } & \text { A003 } \\ \text { L031 } & \text { L020 } \\ \text { L011 } & \text { W033 } \\ \text { W009 } & \text { G025 } \\ \text { M032 } & \text { S035 } \\ \text { F014 } & \text { S026 } \\ \text { R016 } & \text { D010 } \\ \text { R017 } & \text { H025 } \\ \text { J002 } & \text { W026 } \\ \text { J001 } & \text { S047 }\end{array}$

$\mathrm{C} 011$

E013

D014

D029 
RAVOR

Wilderness Study

I S

$7 \quad 7$
OPPOSE

Wilderness l)esignation or

Wilderness Study Status

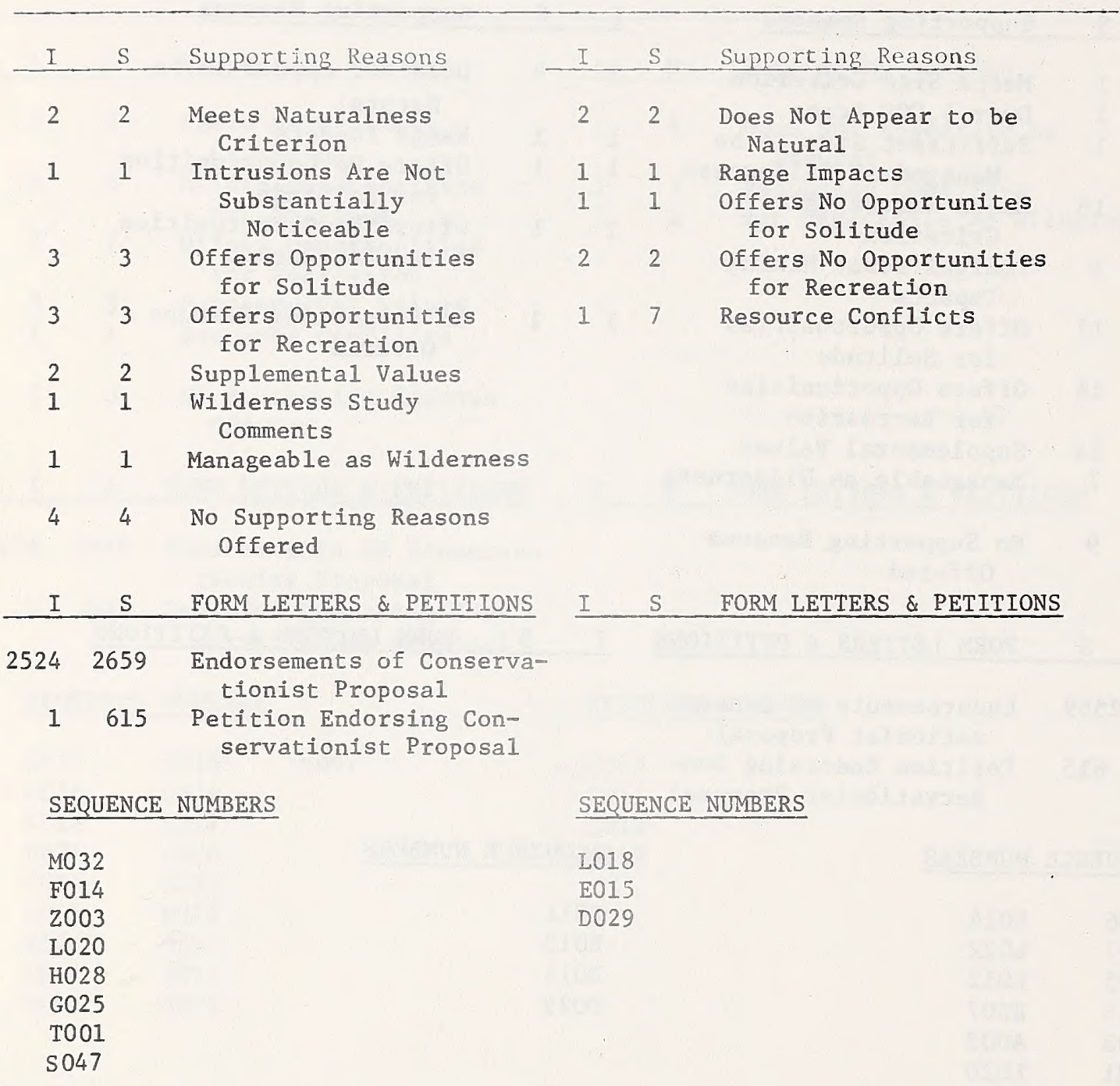


FiVOR

Wilderness Study
OPPOSE

Wilderness lesignation or

Wilderness Study Status

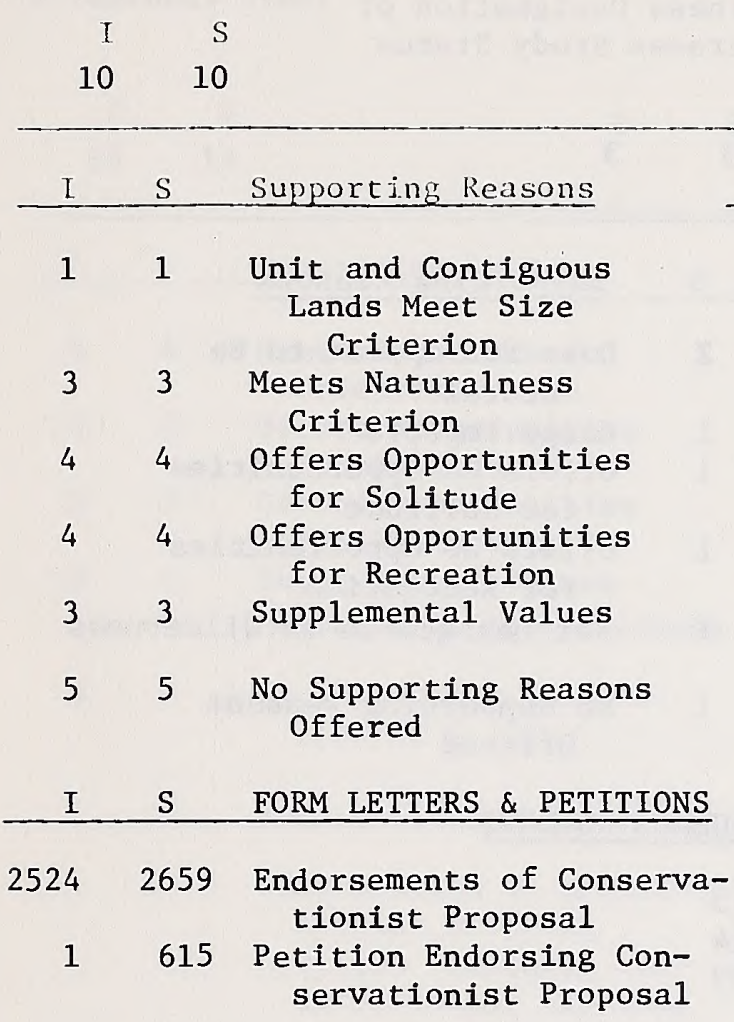

\section{SEQUENCE NUMBERS}

B026

I $\quad \mathrm{S}$

49

I S Supporting Reasons

27 Does Not Appear to be

11 Resource Conflicts

11 No Supporting Reasons offered

I S FORM LETTERS \& PETITIONS

F014

B029

L022

$\mathrm{Z} 003$

K017

L020

W033

D010

H028

$\mathrm{S} 047$

SEQUENCE NUMBERS

$\mathrm{C} 025$

$\mathrm{C} 011$

D029

0001 


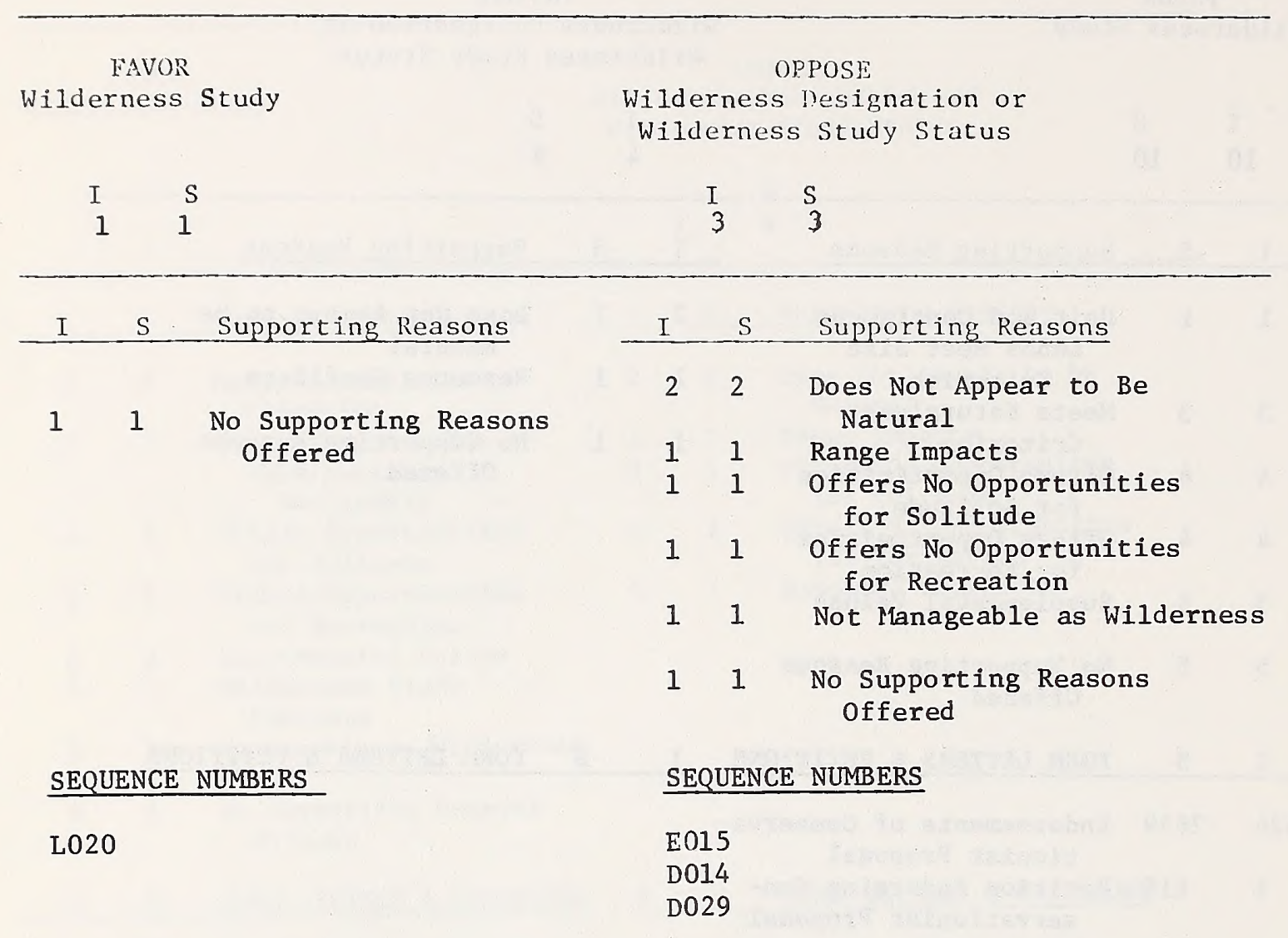




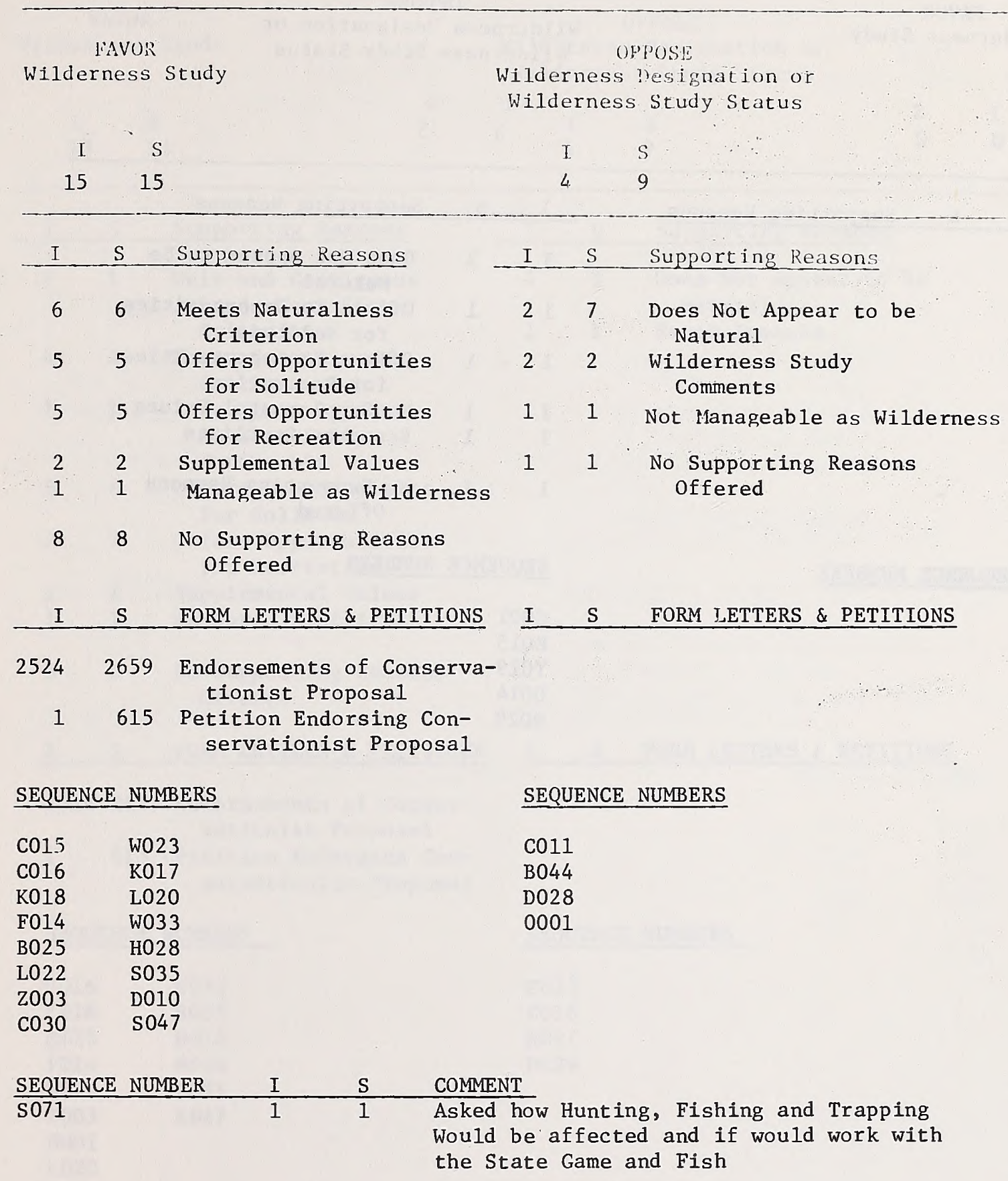


FAVOR

Wilderness Study

I S

I S S Supporting Reasons

\section{OPPOSF}

Wilderness !esignation or

Wilderness Study Status

$\begin{array}{ll}I & S \\ 5 & 5\end{array}$

\begin{tabular}{|c|c|c|}
\hline I & $S$ & Supporting Reasons \\
\hline 3 & 3 & $\begin{array}{l}\text { Does Not Appear to Be } \\
\text { Natural }\end{array}$ \\
\hline 1 & 1 & $\begin{array}{l}\text { Offers No Opportunities } \\
\text { for Solitude }\end{array}$ \\
\hline 1 & 1 & $\begin{array}{l}\text { Offers No Opportunities } \\
\text { for Recreation }\end{array}$ \\
\hline 1 & 1 & No Supplemental Values \\
\hline 1 & 1 & Resource Conflicts \\
\hline 1 & 1 & $\begin{array}{l}\text { No Supporting Reasons } \\
\text { offered }\end{array}$ \\
\hline
\end{tabular}

SEQUENCE NUMBERS

G001

E015

T019

D014

D029 
FAVOR

Wilderness Study
OPPOSE

Wilderness Designation or Wilderness Study Status
I S

$13 \quad 13$
$\begin{array}{ll}I & S \\ 4 & 9\end{array}$
I S S Supporting Reasons

11 Unit and Contiguous Lands Meet Size Criterion

44 Meets Naturalness

Criterion

11 Intrusions Are Not Substantially Noticeable

66 offers Opportunities for Solitude

$7 \quad 7$ Offers Opportunities for Recreation

11 Supplemental Values

11 Resource Conflicts

55 No Supporting Reasons offered

$\begin{array}{ccc}I & S & \text { Supporting Reasons } \\ 4 & 9 & \begin{array}{c}\text { Does Not Appear to Be } \\ \text { Natural }\end{array} \\ 1 & 1 & \begin{array}{c}\text { Range Impacts } \\ \text { nange }\end{array}\end{array}$

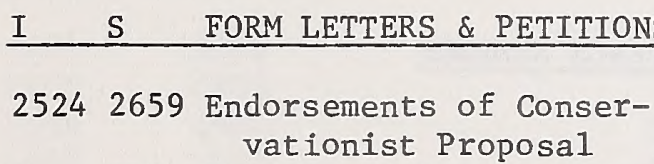

1615 Petition Endorsing Conservationist Proposal

\section{SEQUENCE NUMBERS}

C016 W033

K018 S035

R026 D010

F014 H028

L022 P031

$\mathrm{Z} 003 \quad \mathrm{~S} 047$

0001

L020

\section{SEQUENCE NUMBERS}

C035

$\mathrm{C} 016$

H027

D029 
FAVOR

Wilderness Study

I S

$10 \quad 10$

\section{OPPOSE}

Wilderness lesignation or

Wilderness Study Status

\begin{tabular}{|c|c|c|}
\hline I & $S$ & Supporting Reasons \\
\hline 3 & 3 & $\begin{array}{l}\text { Meets Naturalness } \\
\text { Criterion }\end{array}$ \\
\hline 3 & 3 & $\begin{array}{l}\text { Offers Opportunities } \\
\text { for Solitude }\end{array}$ \\
\hline 3 & 3 & $\begin{array}{l}\text { Offers Opportunities } \\
\text { for Recreation }\end{array}$ \\
\hline 1 & 1 & Manageable as Wildernes \\
\hline 7 & 7 & $\begin{array}{l}\text { No Supporting Reasons } \\
\text { offered }\end{array}$ \\
\hline$\underline{I}$ & $\underline{S}$ & FORM LETTERS \& PETITION \\
\hline 2524 & 2659 & $\begin{array}{l}\text { Endorsements of Conser- } \\
\text { vationist Proposal }\end{array}$ \\
\hline 1 & 615 & $\begin{array}{l}\text { Petition Endorsing Con- } \\
\text { servationist Proposal }\end{array}$ \\
\hline
\end{tabular}

SEQUENCE NUMBERS

\begin{tabular}{|c|c|c|}
\hline I & $\underline{S}$ & Supporting Reasons \\
\hline 1 & 6 & $\begin{array}{l}\text { Does Not Appear to Be } \\
\text { Natural }\end{array}$ \\
\hline 1 & 1 & Range Impacts \\
\hline 1 & 1 & Resource Conflicts \\
\hline 1 & 1 & Not Manageable as Wilderness \\
\hline 1 & 1 & $\begin{array}{l}\text { No Supporting Reasons } \\
\text { offered }\end{array}$ \\
\hline$\underline{I}$ & $\mathrm{~S}$ & FORM LETTERS \& PETITIONS \\
\hline
\end{tabular}

\section{$\mathrm{C} 015$}

W030

H028

S 035

F014

D010

$\mathrm{K} 017 \quad \mathrm{~S} 047$

L020
I S
49 


\section{Unit Number: NM-010-63(a) Unit Name: LaLena}

FAVOR

Wilderness Study

\section{OPPOSE}

Wilderness Nesignation or Wilderness Study Status

I S

$10 \quad 10$

I S

38

\begin{tabular}{|c|c|c|}
\hline I & $S$ & Supporting Reasons \\
\hline 3 & 3 & $\begin{array}{l}\text { Meets Naturalness } \\
\text { Criterion }\end{array}$ \\
\hline 3 & 3 & $\begin{array}{l}\text { Offers Opportunities } \\
\text { for Solitude }\end{array}$ \\
\hline 3 & 3 & $\begin{array}{l}\text { Offers Opportunities } \\
\text { for Recreation }\end{array}$ \\
\hline 1 & 1 & Manageable as Wildert \\
\hline 7 & 7 & $\begin{array}{l}\text { No Supporting Reasons } \\
\text { Offered }\end{array}$ \\
\hline I & $\mathrm{S}$ & FORM LETTERS \& PETITI \\
\hline 2524 & 2659 & $\begin{array}{c}\text { Endorsements of Conse } \\
\text { vationist proposal }\end{array}$ \\
\hline 1 & 615 & $\begin{array}{l}\text { Petition Endorsing Co } \\
\text { servationist Propos }\end{array}$ \\
\hline
\end{tabular}

\section{SEQUENCE NUMBERS}

\begin{tabular}{|c|c|c|}
\hline$I$ & $\underline{s}$ & Supporting Reasons \\
\hline 1 & 6 & $\begin{array}{l}\text { Does Not Appear to Be } \\
\text { Natural }\end{array}$ \\
\hline 1 & 1 & Resource Conflicts \\
\hline 1 & 1 & $\begin{array}{l}\text { No Supporting Reasons } \\
\text { Offered }\end{array}$ \\
\hline
\end{tabular}

$\begin{array}{ll}\text { C015 } & \text { H028 } \\ \text { K018 } & \text { S035 } \\ \text { F014 } & \text { D010 } \\ \text { L022 } & \text { S047 } \\ \text { K017 } & \\ \text { L020 } & \\ \text { W033 } & \end{array}$

SEQUENCE NUMBERS

G025

G011

0011 
FAVOR

Wilderness Study

$\begin{array}{ll}I & S \\ 0 & 0\end{array}$
OPPOSE

Wilderness lesignation or Wilderness Study Status

$\begin{array}{ll}\text { I } & \text { S } \\ 2 & 2\end{array}$
I S Supporting Reasons

SEQUENCE NUMBERS
I S S Support ing Reasons

11 Does Not Meet Size

Criterion

22 Does Not Appear to Be

2 Natural

11 Range Impacts

22 Offers No Opportunities

for Solitude

22 Offers No Opportunities

for Recreation

\section{SEQUENCE NUMBERS}

E015

$\mathrm{H} 027$ 
Unit Number: NM-010-91 Unit Name: Simon

EAVก:

Wilderness study

I S Sumporting Reasons

SEOUENCE NUMBERS
Wilderness study Status

$\begin{array}{ll}1 & S \\ 1 & 1\end{array}$

I S S Supporting Reasons

11 Does Not Appear to Be

Natural

11 Offers No Opportunities

for Solitude

11 Offers No Opportunities

for Recreation

\section{SEQUENCE NUMBERS}

E015 
WAVOR
Wilderness Study

I S

$8 \quad 8$

\section{()PPOSE:}

Wilderness nesignation or

Wilderness study Status

\begin{tabular}{|c|c|c|c|c|}
\hline I & $\mathrm{S}$ & Supporting Reasons & I & Supporting Reasons \\
\hline 2 & 2 & $\begin{array}{l}\text { Meets Naturalness } \\
\text { Criterion }\end{array}$ & 1 & No Supporting Reasons \\
\hline 2 & 2 & $\begin{array}{l}\text { Offers Opportunities } \\
\text { for Solitude }\end{array}$ & & Offered \\
\hline 2 & 2 & $\begin{array}{l}\text { Offers Opportunities } \\
\text { for Recreation }\end{array}$ & & \\
\hline 1 & 1 & Supplemental Values & & \\
\hline 1 & 1 & Manageable as Wilderness & & \\
\hline 5 & 5 & $\begin{array}{l}\text { No Supporting Reasons } \\
\text { offered }\end{array}$ & ant & \\
\hline I & $\mathrm{S}$ & FORM LETTERS \& PETITIONS & $\underline{I}$ & FORM LETTERS \& PETITIONS \\
\hline 2524 & 2659 & $\begin{array}{c}\text { Endorsements of Conser- } \\
\text { vationist Proposal }\end{array}$ & & \\
\hline 1 & 615 & $\begin{array}{l}\text { Petition Endorsing Con- } \\
\text { servationist proposal }\end{array}$ & & \\
\hline \multicolumn{2}{|c|}{ SEQUENCE 1} & NUMBERS & \multicolumn{2}{|c|}{ SEQUENCE NUMBERS } \\
\hline R026 & & D010 & 0001 & \\
\hline F014 & & S047 & & \\
\hline L022 & & & & \\
\hline L020 & & & & \\
\hline W033 & & & & \\
\hline S033 & & & & \\
\hline
\end{tabular}




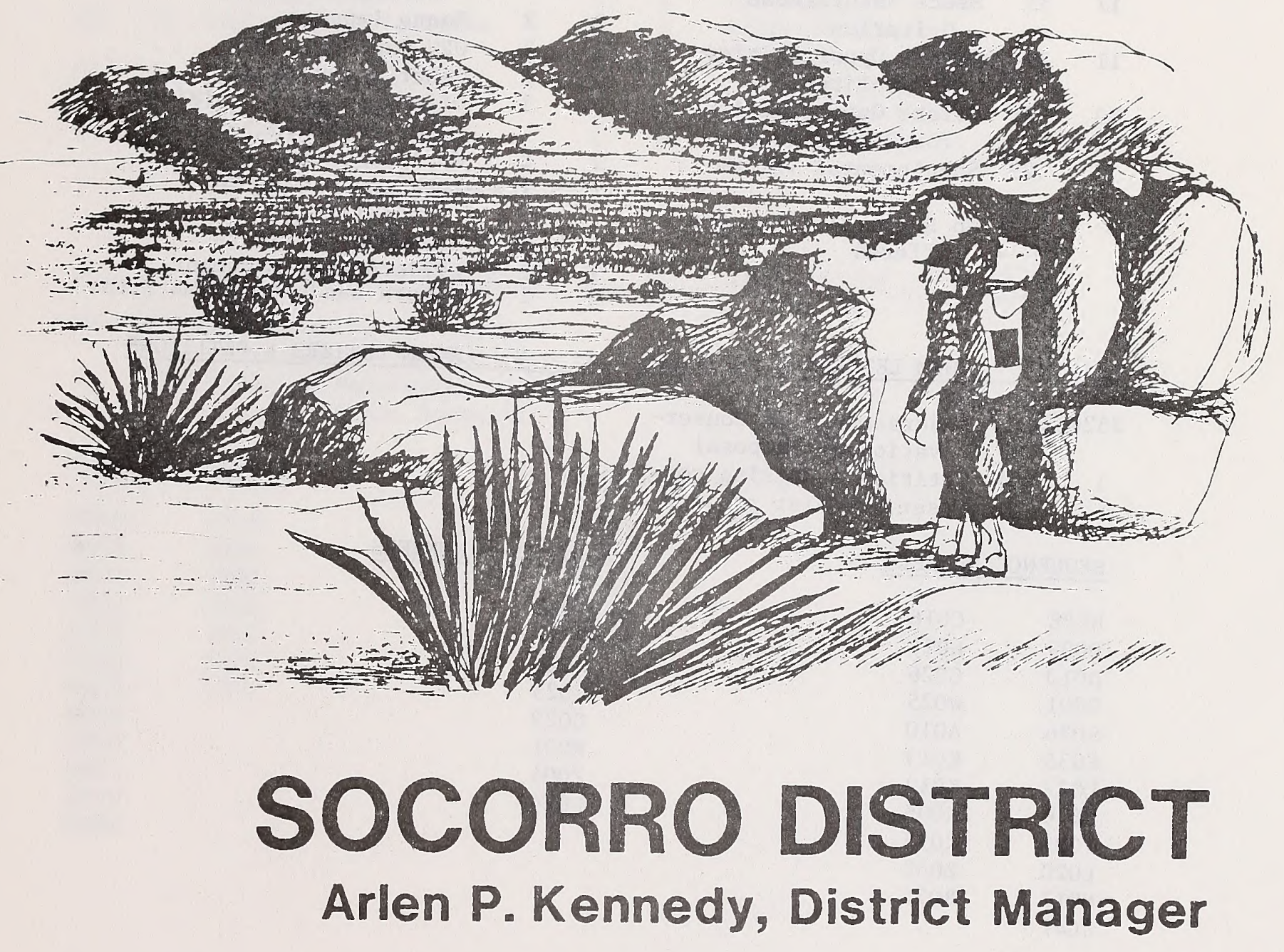


FAVOR

Wilderness Study

I S

$22 \quad 40$
OPPOSE

Wilderness Designation or Wilderness Study Status

I S

98

\begin{tabular}{|c|c|c|}
\hline I & $\mathrm{S}$ & Supporting Reasons \\
\hline 4 & 4 & Meets Size Criterion \\
\hline 12 & 30 & Over 5000 Acres \\
\hline 17 & 35 & $\begin{array}{l}\text { Meets Naturalness } \\
\text { Criterion }\end{array}$ \\
\hline 11 & 29 & $\begin{array}{l}\text { Offers Opportunities } \\
\text { for Solitude }\end{array}$ \\
\hline 13 & 31 & $\begin{array}{l}\text { Offers Opportunities } \\
\text { for Recreation }\end{array}$ \\
\hline 11 & 29 & Supplemental Values \\
\hline 4 & 4 & $\begin{array}{l}\text { No Supporting Reasons } \\
\text { offered }\end{array}$ \\
\hline I & S & FORM LETTERS \& PETITIONS \\
\hline 2524 & 2659 & $\begin{array}{l}\text { Endorsements of Conser- } \\
\text { vationist Proposal }\end{array}$ \\
\hline 1 & 615 & $\begin{array}{l}\text { Petition endorsing con- } \\
\text { servationist proposal }\end{array}$ \\
\hline
\end{tabular}

\section{SEQUENCE NUMBERS}

$\begin{array}{ll}\text { H028 } & \text { C016 } \\ \text { D009 } & \text { E014 } \\ \text { D010 } & \text { C026 } \\ \text { 0001 } & \text { W025 } \\ \text { S026 } & \text { A010 } \\ \text { S035 } & \text { K013 } \\ \text { L022 } & \text { K012 } \\ \text { S036 } & \text { K005 } \\ \text { T005 } & \text { K018 } \\ \text { L020 } & \text { Z003 } \\ \text { M017 } & \text { B035 } \\ \text { S047 } & \end{array}$

\begin{tabular}{|c|c|c|}
\hline I & $\underline{\mathrm{S}}$ & Supporting Reasons \\
\hline 1 & 1 & Under 5000 Acres \\
\hline 3 & 2 & $\begin{array}{l}\text { Does Not Appear to } \mathrm{Be} \\
\text { Natural }\end{array}$ \\
\hline 3 & 2 & Range Impacts \\
\hline 2 & 2 & ORV Damage \\
\hline 1 & 1 & Other Intrusions \\
\hline 4 & 3 & $\begin{array}{l}\text { Offers No Opportunities } \\
\text { for Solitude }\end{array}$ \\
\hline 2 & 2 & No Supplemental Values \\
\hline 1 & 1 & $\begin{array}{l}\text { Intrusions Will Not } \\
\text { Rehabilitate }\end{array}$ \\
\hline 4 & 4 & Resource Conflicts \\
\hline $\begin{array}{l}1 \\
2\end{array}$ & $\begin{array}{l}1 \\
1\end{array}$ & $\begin{array}{l}\text { Wilderness Management } \\
\text { Return Lands to Acoma Tribe }\end{array}$ \\
\hline$\underline{I}$ & $\mathrm{~S}$ & FORM LETTERS \& PETITIONS \\
\hline
\end{tabular}

\section{SEQUENCE NUMBERS}

D029

C027

$\mathrm{P} 028$

$\mathrm{C} 025$

C029

R001

Z004

L024 
FAVOR

Wilderness Study

I S

$18 \quad 19$

\section{OPPOSE}

Wilderness Designation or Wilderness Study Status

I $\quad S$

65

\begin{tabular}{|c|c|c|}
\hline$I$ & $\mathrm{~S}$ & Supporting Reasons \\
\hline 2 & 2 & Meets Size Criterion \\
\hline 14 & 15 & Over 5000 Acres \\
\hline 14 & 14 & $\begin{array}{l}\text { Meets Naturalness } \\
\text { Criterion }\end{array}$ \\
\hline 10 & 10 & $\begin{array}{l}\text { Offers Opportunities } \\
\text { for Solitude }\end{array}$ \\
\hline 10 & 10 & $\begin{array}{l}\text { Offers Opportunities } \\
\text { for Recreation }\end{array}$ \\
\hline 11 & 11 & Supplemental Values \\
\hline 4 & 5 & $\begin{array}{l}\text { No Supporting Reasons } \\
\text { offered }\end{array}$ \\
\hline I & S & FORM LETTERS \& PETITION \\
\hline 2524 & 2659 & $\begin{array}{l}\text { Endorsements of Conser- } \\
\text { vationist Proposal }\end{array}$ \\
\hline 1 & 615 & $\begin{array}{l}\text { Petition endorsing con- } \\
\text { servationist Proposal }\end{array}$ \\
\hline
\end{tabular}

SEQUENCE NUMBERS

$\begin{array}{ll}\text { D009 } & \text { L019 } \\ \text { H028 } & \text { Z003 } \\ \text { D010 } & \text { K018 } \\ \text { S026 } & \text { B026 } \\ \text { S035 } & \text { F014 } \\ \text { S036 } & \text { L022 } \\ \text { L020 } & \text { S047 } \\ \text { M026 } & \\ \text { C026 } & \\ \text { W023 } & \\ \text { A010 } & \\ \text { K005 } & \end{array}$

I S Supporting Reasons

21 Does Not Appear to Be

Natural

43 Range Impacts

11 ORV Damage

11 Other Intrusions

32 Offers No Opportunities for Solitude

33 Resource Conflicts

11 Not Manageable as Wilderness

I S FORM LETTERS \& PETITIONS

SEQUENCE NUMBERS

D029

$\mathrm{C} 027$

$\mathrm{P} 028$

Z004

L024 


\section{FAVOR}

Wilderness Study

$\begin{array}{lr}I & \text { S } \\ 15 & 34\end{array}$
OPPOSE

Wilderness Iesignation or Wilderness Study Status

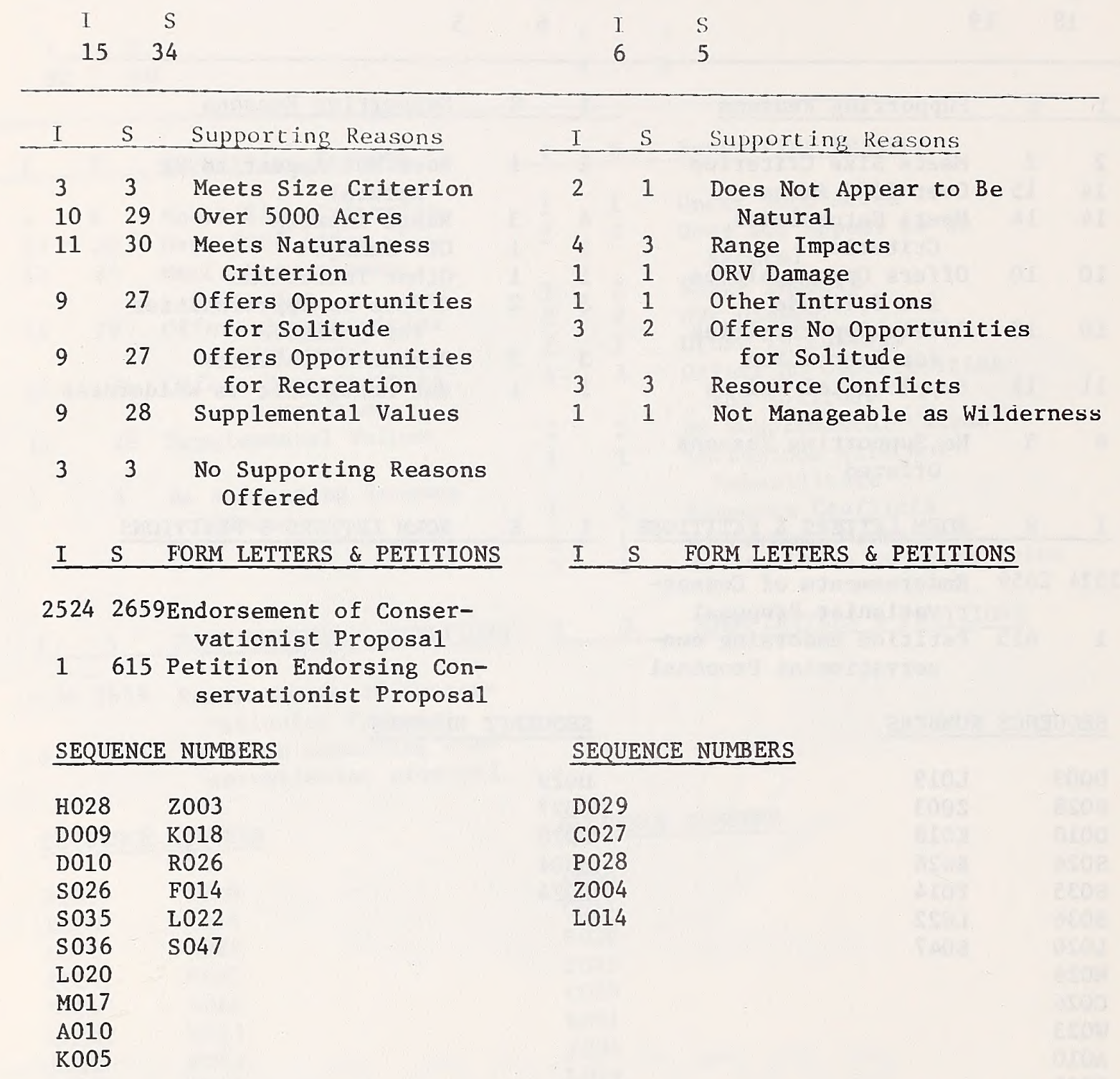


FAVOR

Wilderness Study

$15 \quad 16$

\begin{tabular}{|c|c|c|}
\hline 1 & S & Supporting Reasons \\
\hline 2 & 2 & Meets Size Criterion \\
\hline 9 & 10 & Over 5000 Acres \\
\hline 11 & 11 & $\begin{array}{l}\text { Meets Naturalness } \\
\text { Criterion }\end{array}$ \\
\hline 8 & 8 & $\begin{array}{l}\text { Offers Opportunities } \\
\text { for Solitude }\end{array}$ \\
\hline 8 & 8 & $\begin{array}{l}\text { Offers Opportunities } \\
\text { for Recreation }\end{array}$ \\
\hline 7 & 8 & Supplemental Values \\
\hline 3 & 3 & $\begin{array}{l}\text { No Supporting Reasons } \\
\text { Offered }\end{array}$ \\
\hline$\underline{I}$ & $\mathrm{~S}$ & FORM LETTERS \& PETITIONS \\
\hline 2524 & 2659 & $\begin{array}{l}\text { Endorsements of Conser- } \\
\text { vationist Proposal }\end{array}$ \\
\hline 1 & 615 & $\begin{array}{l}\text { Petition Endorsing Con- } \\
\text { servationist proposal }\end{array}$ \\
\hline
\end{tabular}

\section{SEQUENCE NUMBERS}

$\begin{array}{ll}\text { H028 } & \text { K005 } \\ \text { D009 } & \text { Z003 } \\ \text { D010 } & \text { K018 } \\ \text { S026 } & \text { F014 } \\ \text { S035 } & \text { L022 } \\ \text { S036 } & \text { S047 } \\ \text { L020 } & \\ \text { M017 } & \\ \text { W023 } & \\ \text { A010 } & \end{array}$

I S Supporting Reasons

11 Does Not Appear to Be

Natural

43 Range Impacts

11 ORV Damage

11 Outside Sights and

Sounds

11 Other Intrusions

32 Offers No Opportunities

for Solitude

33 Resource Conflicts

11 Not Manageable as Wilderness

I S FORM LETTERS \& PETITIONS

\section{SEQUENCE NUMBERS}
D029
$\mathrm{C} 027$
$\mathrm{P} 028$
$\mathrm{CO} 25$
Z004
L024 
RAVOR

Wilderness Study

\section{OPPOST}

Wilderness lesignation or

Wilderness Study Status

I S

I. $S$

\begin{tabular}{|c|c|c|}
\hline I & $\underline{S}$ & Supporting Reasons \\
\hline 6 & 5 & Over 5000 Acres \\
\hline 5 & 4 & $\begin{array}{l}\text { Meets Naturalness } \\
\text { Criterion }\end{array}$ \\
\hline 2 & 1 & $\begin{array}{l}\text { Intrusions Are Not Sub- } \\
\text { stantially Noticeable }\end{array}$ \\
\hline 5 & 4 & $\begin{array}{l}\text { Offers Opportunities } \\
\text { for Solitude }\end{array}$ \\
\hline 4 & 3 & $\begin{array}{l}\text { Offers Opportunities } \\
\text { for Recreation }\end{array}$ \\
\hline 4 & 3 & Supplemental Values \\
\hline 2 & 1 & Manageable as Wilderness \\
\hline 1 & 1 & $\begin{array}{l}\text { No Supporting Reasons } \\
\text { Offered }\end{array}$ \\
\hline
\end{tabular}
Supporting Reasons

\section{SEQUENCE NUMBERS}




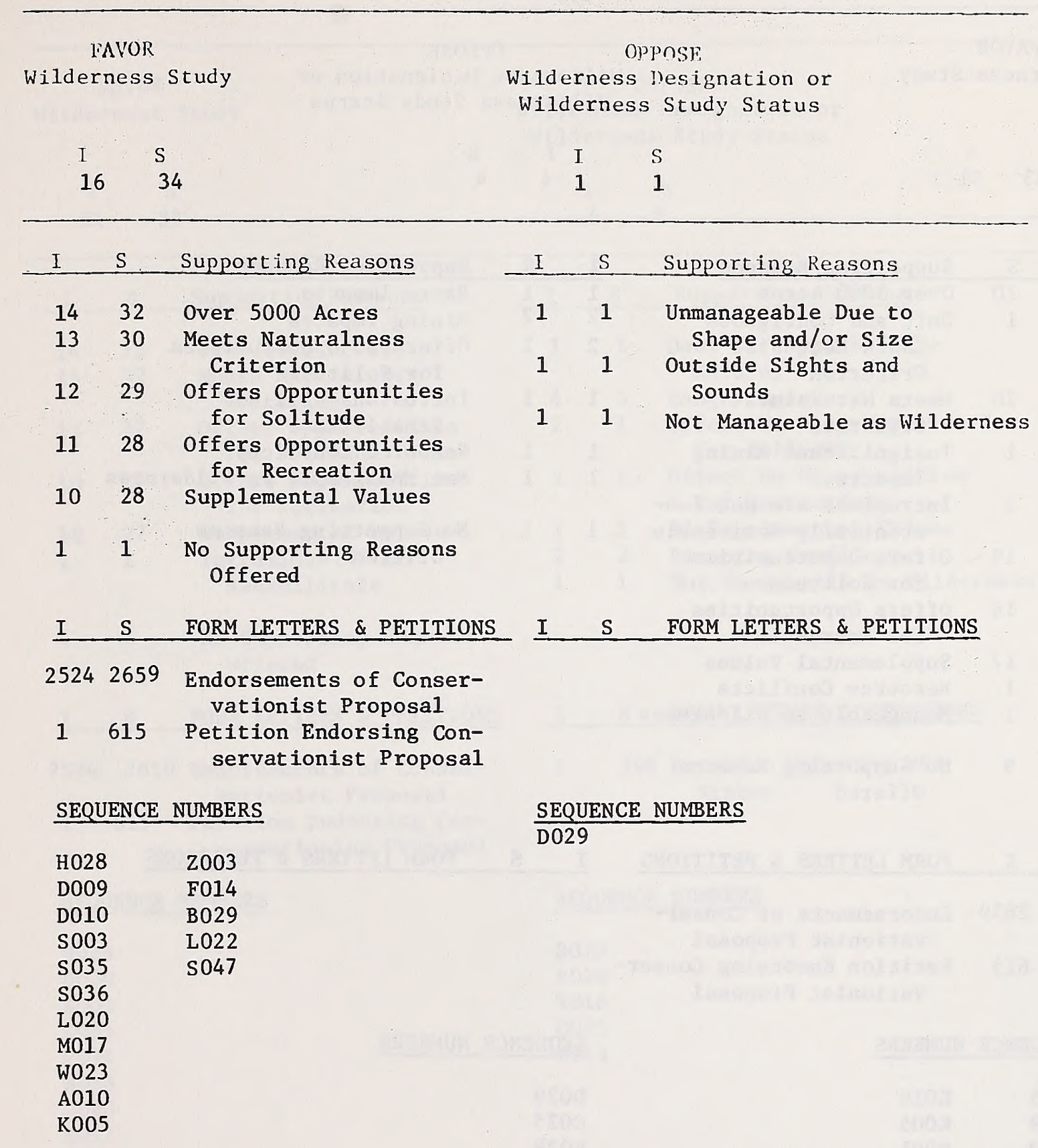


FAYOR

Wilderness Study

L $\quad \mathrm{S}$

$33 \quad 31$
OPPOSF

Wilderness llesignation or

Wilderness Study Status
$\frac{I}{22}-\frac{S}{20} \quad \frac{\text { Supporting Reasons }}{\text { Over } 5000 \text { Acres }}$

11 Unit and Contiguous

Lands Meet Size

Criterion

$22 \quad 20$ Meets Naturalness

Criterion

11 Insignificant Mining

Impacts

32 Intrusions Are Not Substantially Noticeable

2119 Offers Opportunities

for Solitude

1716 offers Opportunities

for Recreation

1817 Supplemental Values

11 Resource Conflicts

11 Manageable as Wilderness

99 No Supporting Reasons offered

I S FORM LETTERS \& PETITIONS

25242659 Endorsements of Conservationist Proposal

1615 Petition Endorsing Conservationist Proposal

\section{SEQUENCE NUMBERS}

$\begin{array}{ll}\text { H028 } & \text { K010 } \\ \text { D009 } & \text { K005 } \\ \text { D010 } & \text { B001 } \\ \text { S 003 } & \text { G025 } \\ \text { S 026 } & \text { Z003 } \\ \text { S 035 } & \text { K018 } \\ \text { L033 } & \text { B026 } \\ \text { S 036 } & \text { W009 } \\ \text { T015 } & \text { M032 } \\ \text { L020 } & \text { F014 } \\ \text { M017 } & \text { L022 } \\ \text { C012 } & \text { O001 } \\ \text { C004 } & \text { B001 } \\ \text { K017 } & \text { F026 } \\ \text { L028 } & \text { P 031 } \\ \text { P015 } & \text { S } 047\end{array}$

$\frac{I}{1} \quad$ S $\quad$ Supporting Reasons

22 Mining Impacts

22 Offers No Opportunities

for Solitude

11 Intrusions Will Not Rehabilitate

11 Resource Conflicts

11 Not Manageable as Wilderness

11 No Supporting Reasons offered

\section{S FORM LETTERS \& PETITIONS}

\section{SEQUENCE NUMBERS}

D029

$\mathrm{C} 025$

B028

$\mathrm{C} 038$ 
FAYOR

Wilderness Study
OPPOSE

Wilderness lesignation or

Wilderness Study Status
I S

$21 \quad 37$
I S

\begin{tabular}{|c|c|c|}
\hline I & S & Supporting Reasons \\
\hline 14 & 31 & Over 5000 Acres \\
\hline 15 & 32 & $\begin{array}{l}\text { Meets Naturalness } \\
\text { Criterion }\end{array}$ \\
\hline 15 & 32 & $\begin{array}{l}\text { Offers Opportunities } \\
\text { for Solitude }\end{array}$ \\
\hline 10 & 27 & $\begin{array}{l}\text { Offers Opportunities } \\
\text { for Recreation }\end{array}$ \\
\hline 10 & 27 & Supplemental Values \\
\hline 1 & 1 & $\begin{array}{c}\text { Intrusions Will } \\
\text { Rehabilitate }\end{array}$ \\
\hline 4 & 4 & $\begin{array}{l}\text { No Supporting Reasons } \\
\text { offered }\end{array}$ \\
\hline I & $\mathrm{S}$ & FORM LETTERS \& PETITIONS \\
\hline 2524 & 2659 & $\begin{array}{c}\text { Endorsements of Conser- } \\
\text { vationist Proposal }\end{array}$ \\
\hline 1 & 615 & $\begin{array}{l}\text { Petition Endorsing Con- } \\
\text { servationist Proposal }\end{array}$ \\
\hline
\end{tabular}

SEQUENCE NUMBERS
$\mathrm{H} 028$
D009
$\mathrm{S} 003$
S 035
$\mathrm{P} 031$
$\mathrm{S} 036$
L020
$\mathrm{M} 017$
C015
K017
W023
A019
K009
K005
F019
Z003
K018
F014
F026
L022
S047

I S Supporting Reasons

11 Does Not Appear to Be Natural

43 Range Impacts

21 Offers No Opportunities

for Solitude

22 Offers No Opportunities

for Recreation

11 No Supplemental Values

22 Resource Conflicts

11 Not Manageable as Wilderness
SEQUENCE NUMBERS

D029

P028

T016

$\mathrm{C} 025$

F013 


\section{FAVOR}

Wilderness Study
OPPOSE

Wilderness !esignation or Wilderness Study Status
I S

$22 \quad 38$ $\begin{array}{ll}\text { I } & \text { S } \\ 5 & 4\end{array}$

\section{S S Supporting Reasons \\ 11 Meets Size Criterion \\ 1431 Over 5000 Acres \\ 1431 Meets Naturalness \\ 1431 offers Opportunities for Solitude \\ 1128 Offers Opportunities \\ $\begin{array}{llc}\text { for Recreation } \\ 10 \quad 27 & \text { Supplemental Values }\end{array}$ \\ $7 \quad 7$ No Supporting Reasons offered \\ I S F FORM LETTERS \& PETITIONS}

25242659 Endorsements of Conservationist Proposal

1615 Petition Endorsing Conservationist Proposal

\section{SEQUENCE NUMBERS}

H028

D010

B026

W026

D009 M032

S003 F014

$\mathrm{S} 036 \quad$ L022

S035 P031

L020 S047

M017

$\mathrm{C} 015$

$\mathrm{C} 026$

K017

พ023

K009

$\mathrm{Z} 003$

K018

\begin{tabular}{|c|c|c|}
\hline I & $\underline{S}$ & Supporting Reasons \\
\hline 2 & 1 & $\begin{array}{l}\text { Does Not Appear to } \mathrm{Be} \\
\text { Natural }\end{array}$ \\
\hline 4 & 3 & Range Impacts \\
\hline 1 & 1 & $\begin{array}{l}\text { Offers No Opportunities } \\
\text { for Solitude }\end{array}$ \\
\hline 1 & 1 & $\begin{array}{l}\text { Offers No Opportunities } \\
\text { for Recreation }\end{array}$ \\
\hline 1 & 1 & No Supplementa1 Values \\
\hline 2 & 2 & Resource Conflicts \\
\hline
\end{tabular}

I S FORM LETTERS \& PETITIONS

1398 Petitions Opposing WSA Status

SEQUENCE NUMBERS

D029

P026

T016

F026

F013 


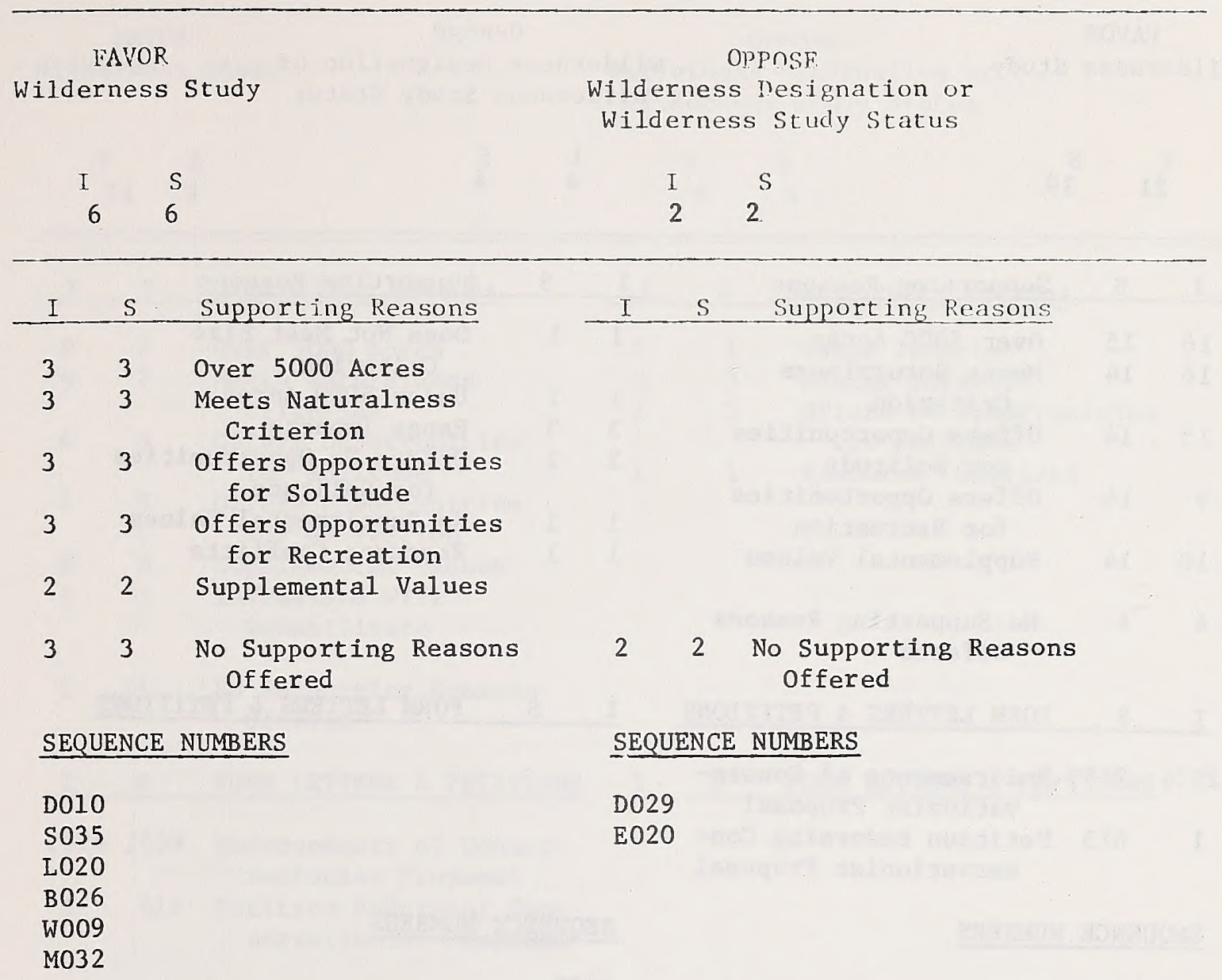


FAVOR

Wilderness Study

$\mathrm{S}$

$21 \quad 19$
Opprse

Wilderness lesignation or Wilderness study status

\begin{tabular}{|c|c|c|}
\hline I & $\mathrm{S}$ & Supporting Reasons \\
\hline 16 & 15 & Over 5000 Acres \\
\hline 16 & 14 & $\begin{array}{l}\text { Meets Naturalness } \\
\text { Criterion }\end{array}$ \\
\hline 15 & 14 & $\begin{array}{l}\text { Offers Opportunities } \\
\text { for Solitude }\end{array}$ \\
\hline 9 & 14 & $\begin{array}{l}\text { Offers Opportunities } \\
\text { for Recreation }\end{array}$ \\
\hline 10 & 14 & Supplemental Values \\
\hline 4 & 4 & $\begin{array}{l}\text { No Supporting Reasons } \\
\text { Offered }\end{array}$ \\
\hline$\underline{I}$ & $\mathrm{~S}$ & FORM LETTERS \& PETITIONS \\
\hline 2524 & 2659 & $\begin{array}{c}\text { Endorsements of Conser- } \\
\text { vationist Proposal }\end{array}$ \\
\hline 1 & 615 & $\begin{array}{l}\text { Petition Endorsing Con- } \\
\text { servationist Proposal }\end{array}$ \\
\hline
\end{tabular}

\section{SEQUENCE NUMBERS}

$\begin{array}{ll}\text { H028 } & \text { A004 } \\ \text { D009 } & \text { B026 } \\ \text { D010 } & \text { F026 } \\ \text { S003 } & \text { F014 } \\ \text { S035 } & \text { L022 } \\ \text { S036 } & \text { S047 }\end{array}$

\begin{tabular}{|c|c|c|}
\hline$I$ & $S$ & Supporting Reasons \\
\hline 1 & 1 & $\begin{array}{l}\text { Does Not Meet Size } \\
\text { Criterion }\end{array}$ \\
\hline 1 & 1 & Under 5000 Acres \\
\hline 3 & 3 & Range Impacts \\
\hline 2 & 2 & $\begin{array}{l}\text { Offers No Opportunities } \\
\text { for Solitude }\end{array}$ \\
\hline 1 & 1 & No Supplemental Values \\
\hline 1 & 1 & Resource Conflicts \\
\hline
\end{tabular}

\section{S FORM LETTERS \& PETITIONS}

\section{SEQUENCE NUMBERS}

D029

M029

M023

G029 
FAVOR

Wilderness Study

\section{OPPOSF}

Wilderness !esignation or

Wilderness Study Status

I S

119

$\begin{array}{ll}\text { I } & \text { S } \\ 4 & 4\end{array}$

I S S Supporting Reasons

11 Range Impacts

33 Mining Impacts

22 Offers No Opportunities

for Solitude

11 Resource Conflicts

75 offers Opportunities for Recreation

86 Supplemental Values

11 Intrusions Will Rehabilitate

11 No Supporting Reasons offered

I S FORM LETTERS \& PETITIONS

I S FORM LETTERS \& PETITIONS

25242659 Endorsements of Conservationist Proposal

1615 Petition Endorsing Conservationist Proposal

\section{SEQUENCE NUMBERS}

H028

D010

$\mathrm{S} 003$

S035

$\mathrm{S} 036$

L020

$\mathrm{A} 004$

F014

F029

S 047

\section{SEQUENCE NUMBERS}

H005

D029

D007

G029 


\section{FAYOR}

Wilderness Study

I $\quad$ S

I S S Supporting Reasons

11 Meets Size Criterion

1934 Over 5000 Acres

2238 Meets Naturalness Criterion

2036 Offers Opportunities for Solitude

1430 Offers Opportunities for Recreation

1430 Supplemental Values

99 No Supporting Reasons offered

\section{Oppost}

Wilderness lesignation or

Wilderness Study Status I $S$ $24 \quad 30$

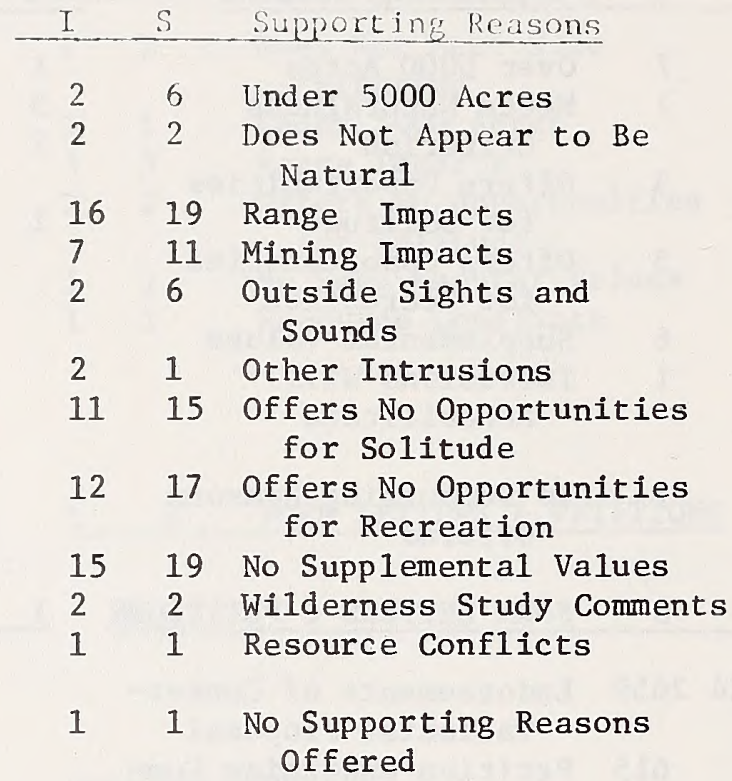

I S FORM LETTERS \& PETITIONS

I S FORM LETTERS \& PETITIONS

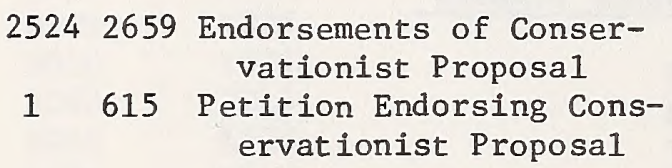

\section{SEQUENCE NUMBERS}

$\begin{array}{ll}\text { H028 } & \text { K013 } \\ \text { D009 } & \text { K005 } \\ \text { D010 } & \text { F019 } \\ \text { S003 } & \text { A004 } \\ \text { S035 } & \text { Z003 } \\ \text { S061 } & \text { K018 } \\ \text { S036 } & \text { W009 } \\ \text { T005 } & \text { M032 } \\ \text { L020 } & \text { F014 } \\ \text { M017 } & \text { L022 } \\ \text { L015 } & \text { F029 } \\ \text { K017 } & \text { F026 } \\ \text { L028 } & \text { P031 } \\ \text { W023 } & \text { S047 } \\ \text { A010 } & \end{array}$

SEQUENCE NUMBERS

$\begin{array}{ll}\text { D029 } & \text { L025 } \\ \text { S055 } & \text { D024 } \\ \text { W029 } & \text { D025 } \\ \text { F018 } & \text { C027 } \\ \text { H034 } & \text { E008 } \\ \text { H033 } & \text { G029 } \\ \text { H031 } & \text { A007 }\end{array}$

$\mathrm{A} 007$

R004

R019

R020

V008

A009

$\mathrm{Z} 004$

G016

G015

SEQUENCE NUMBERS I $S$ COMMENTS

$\mathrm{A} 007$

as misled into believing the area had already been dropped. 
IAVOR

Wilderness Study

\section{oppris}

Wilderness ?esignation or Wilderness Study Status

I $\quad S$

$16 \quad 15$

$\begin{array}{lc}\text { I } & \text { S } \\ 6 & 12\end{array}$

\begin{tabular}{|c|c|c|}
\hline I & $\mathrm{S}$ & Supporting Reasons \\
\hline 9 & 8 & Over 5000 Acres \\
\hline 8 & 7 & $\begin{array}{l}\text { Meets Naturalness } \\
\text { Criterion }\end{array}$ \\
\hline 1 & 1 & $\begin{array}{l}\text { Intrusions Are Not Sub- } \\
\text { stantially Noticeable }\end{array}$ \\
\hline 8 & 7 & $\begin{array}{l}\text { Offers Opportunities for } \\
\text { Solitude }\end{array}$ \\
\hline 7 & 7 & $\begin{array}{l}\text { Offers Opportunities for } \\
\text { Recreation }\end{array}$ \\
\hline 7 & 6 & Supplemental Values \\
\hline 7 & 7 & $\begin{array}{l}\text { No Supporting Reasons } \\
\text { Offered }\end{array}$ \\
\hline
\end{tabular}

I S FORM LETTERS \& PETITIONS

25242659 Endorsements of Conservationist Proposal

1615 Petition Endorsing Conservationist Proposal

\section{SEQUENCE NUMBERS}

D010

$\mathrm{S} 003$

M032

F014

S035 L022

F026 B002

L020 A010

K017 5047

R003

K005

B001

พ009

\begin{tabular}{|c|c|c|}
\hline 2 & 2 & $\begin{array}{l}\text { Does Not Meet Size } \\
\text { Criterion }\end{array}$ \\
\hline 1 & 6 & Under 5000 Acres \\
\hline 4 & 9 & $\begin{array}{l}\text { Does Not Appear to Be } \\
\text { Natural }\end{array}$ \\
\hline 2 & 7 & Range Impacts \\
\hline 2 & 7 & Mining Impacts \\
\hline 1 & 6 & $\begin{array}{l}\text { Outside Sights and } \\
\text { Sounds }\end{array}$ \\
\hline 1 & 6 & $\begin{array}{l}\text { Offers No Opportunities } \\
\text { for Solitude }\end{array}$ \\
\hline 1 & 6 & $\begin{array}{l}\text { Offers No Opportunities } \\
\text { for Recreation }\end{array}$ \\
\hline 2 & 7 & No Supplemental Values \\
\hline 1 & 1 & Resource Conflicts \\
\hline 1 & 1 & $\begin{array}{l}\text { No Supporting Reasons } \\
\text { Offered }\end{array}$ \\
\hline I & $\mathrm{s}$ & FORM LETTERS \& PETITIONS \\
\hline
\end{tabular}

1185 Petition

SEQUENCE NUMBERS

D029

E020

$\mathrm{Z} 004$

F019

A007

G029

$\mathrm{A} 007$ 
FAVOR

Wilderness Study

I S

$27 \quad 43$

\section{OpPOSE}

Wilderness lesignation or

Wilderness Study Status

\begin{tabular}{|c|c|c|}
\hline I & S & Supporting Reasons \\
\hline 1 & 1 & Meets Size Criterion \\
\hline 19 & 36 & Over 5000 Acres \\
\hline 20 & 37 & $\begin{array}{l}\text { Meets Naturalness } \\
\text { Criterion }\end{array}$ \\
\hline 20 & 37 & $\begin{array}{l}\text { Offers Opportunities } \\
\text { for Solitude }\end{array}$ \\
\hline 10 & 27 & $\begin{array}{l}\text { Offers Opportunities } \\
\text { for Recreation }\end{array}$ \\
\hline 15 & 32 & Supplemental Values \\
\hline 7 & 7 & $\begin{array}{l}\text { No Supporting Reasons } \\
\text { Offered }\end{array}$ \\
\hline I & $\mathrm{S}$ & FORM LETTERS \& PETITIONS \\
\hline 2524 & 2659 & $\begin{array}{l}\text { Endorsements of Conser- } \\
\text { vationist Proposal }\end{array}$ \\
\hline 1 & 615 & $\begin{array}{l}\text { Petition Endorsing Con- } \\
\text { servationist Proposal }\end{array}$ \\
\hline
\end{tabular}

SEQUENCE NUMBERS

I S S Supporting Reasons

11 Range Impacts

11 Offers No Opportunities for Solitude

11 No Supporting Reasoris offered

$\begin{array}{ll}\text { H028 } & \text { K013 } \\ \text { D009 } & \text { K009 } \\ \text { D014 } & \text { K005 } \\ \text { D010 } & \text { B001 } \\ \text { S003 } & \text { B026 } \\ \text { S035 } & \text { W009 } \\ \text { S061 } & \text { F014 } \\ \text { S036 } & \text { L022 } \\ \text { T006 } & \text { B001 } \\ \text { L020 } & \text { F026 } \\ \text { M027 } & \text { P031 } \\ \text { C015 } & \text { S047 } \\ \text { K017 } & \\ \text { W023 } & \\ \text { A010 } & \end{array}$

SEQUENCE NUMBERS

D029

K003

F013 
FAVOR

Wilderness Study
OPPOSE

Wilderness Designation or Wilderness Study Status

I $\quad$ S

$\begin{array}{ll}{ }^{I} & \text { S } \\ 6 & 6\end{array}$

\begin{tabular}{|c|c|c|}
\hline I & $\underline{S}$ & Supporting Reasons \\
\hline 1 & 1 & Meets Size Criterion \\
\hline 21 & 37 & Over 5000 Acres \\
\hline 20 & 36 & $\begin{array}{l}\text { Meets Naturalness } \\
\text { Criterion }\end{array}$ \\
\hline 21 & 37 & Offers Solitude \\
\hline 15 & 31 & Offers Recreation \\
\hline 18 & 34 & Supplemental Values \\
\hline 1 & 1 & $\begin{array}{c}\text { Intrusions Will } \\
\text { Rehabilitate }\end{array}$ \\
\hline 2 & 2 & Resource Conflicts \\
\hline 7 & 7 & $\begin{array}{l}\text { No Supporting Reasons } \\
\text { offered }\end{array}$ \\
\hline I & $\mathrm{S}$ & FORM LETTERS \& PETITIONS \\
\hline 1 & 615 & $\begin{array}{l}\text { Petition Endorsing Con- } \\
\text { servationist Proposal }\end{array}$ \\
\hline 2524 & 2659 & $\begin{array}{c}\text { Endorsements of Conser- } \\
\text { vationist Proposal }\end{array}$ \\
\hline
\end{tabular}

SEQUENCE NUMBERS

\begin{tabular}{|c|c|c|}
\hline I & $\mathrm{S}$ & Supporting Reasons \\
\hline 4 & 4 & Range Impacts \\
\hline 4 & 4 & Other Intrusions \\
\hline 1 & 1 & Not Manageable as Wilderness \\
\hline 2 & 2 & $\begin{array}{l}\text { No Supporting Reasons } \\
\text { offered }\end{array}$ \\
\hline
\end{tabular}

I S FORM LETTERS \& PETITIONS

1398 Petition

SEQUENCE NUMBERS

$\begin{array}{ll}\text { H028 } & \text { A010 } \\ \text { D009 } & \text { K013 } \\ \text { D010 } & \text { K009 } \\ \text { S003 } & \text { K005 } \\ \text { S026 } & \text { B001 } \\ \text { S035 } & \text { Z003 } \\ \text { S061 } & \text { B026 } \\ \text { T005 } & \text { F014 } \\ \text { E020 } & \text { B 001 } \\ \text { L020 } & \text { L022 } \\ \text { M027 } & \text { R001 } \\ \text { C016 } & \text { F026 } \\ \text { W020 } & \text { P031 } \\ \text { K017 } & \text { S047 } \\ \text { C015 } & \end{array}$

D029

F022

F021

F020

F017

A020

F013 
FAYOR

Wilderness Study

I S

$25 \quad 41$

\section{OPJOSF}

Wilderness besignation or

Wilderness Study Status

\begin{tabular}{|c|c|c|}
\hline I & $\mathrm{S}$ & Supporting Reasons \\
\hline 13 & 33 & Over 5000 Acres \\
\hline 2 & 2 & $\begin{array}{l}\text { Unit and Contiguous } \\
\text { Lands Meet Size } \\
\text { Criterion }\end{array}$ \\
\hline 1 & 1 & $\begin{array}{l}\text { Sufficient Size to Be } \\
\text { Managed as Wilderness }\end{array}$ \\
\hline 16 & 32 & $\begin{array}{l}\text { Meets Naturalness } \\
\text { Criterion }\end{array}$ \\
\hline 15 & 31 & $\begin{array}{l}\text { Offers Opportunities } \\
\text { for Solitude }\end{array}$ \\
\hline 11 & 27 & $\begin{array}{l}\text { Offers Opportunities } \\
\text { for Recreation }\end{array}$ \\
\hline 11 & 27 & Supplemental Values \\
\hline 9 & 9 & $\begin{array}{l}\text { No Supporting Reasons } \\
\text { offered }\end{array}$ \\
\hline$\underline{I}$ & $\mathrm{~S}$ & FORM LETTERS \& PETITIONS \\
\hline 2524 & 2659 & $\begin{array}{c}\text { Endorsements of Conser- } \\
\text { vationist Proposal }\end{array}$ \\
\hline 1 & 615 & $\begin{array}{l}\text { Petition Endorsing Con- } \\
\text { servationist Proposal }\end{array}$ \\
\hline
\end{tabular}

SEQUENCE NUMBERS

$\begin{array}{ll}\text { H028 } & \text { A010 } \\ \text { D009 } & \text { K013 } \\ \text { D010 } & \text { K005 } \\ \text { S003 } & \text { K018 } \\ \text { S026 } & \text { B026 } \\ \text { S035 } & \text { F026 } \\ \text { P031 } & \text { F014 } \\ \text { S036 } & \text { K015 } \\ \text { L020 } & \text { L022 } \\ \text { M026 } & \text { S047 } \\ \text { C016 } & \\ \text { C015 } & \\ \text { C026 } & \\ \text { K017 } & \end{array}$

I S Supporting Reasons

$2 \quad 2$ Under 5000 Acres

11 Unmanageable Due to

11 Does Not Appear to

Be Natural

11 Range Impacts

11 Offers No Opportunities

for Solitude

11 Offers No Opportunities

for Recreation

I S FORM LETTERS \& PETITIONS
SEQUENCE NUMBERS

S 060

T009

T020

$\mathrm{Z} 004$ 
FAVOR

Wilderness Study

\section{OpPOSE}

Wilderness lesignation or

Wilderness Study Status
I $\quad \mathrm{S}$

$15 \quad 31$ $\begin{array}{ll}\text { I } & \text { S } \\ 4 & 4\end{array}$

$\begin{array}{ll}I & \mathbb{S} \\ 8 & 25 \\ 5 & 4\end{array}$

Supporting Reasons

Over 5000 Acres

Unit and Contiguous Lands Meet Size Criterion

1127 Meets Naturalness

$1 \quad 1$ Other Insignificant Intrusions

11 Intrusions Are Not Substantially Noticeable

723 Offers Opportunities for Solitude

925 Offers Opportunities for Recreation

523 Supplemental Values

55 No Supporting Reasons offered

I S FORM LETTERS \& PETITIONS

25242659

Endorsements of Conservationist Proposal

1615 Petition Endorsing Conservationist Proposa 1

\section{SEQUENCE NUMBERS}

$\begin{array}{ll}\text { H028 } & \text { K018 } \\ \text { D010 } & \text { B016 } \\ \text { S003 } & \text { F014 } \\ \text { S026 } & \text { L022 } \\ \text { L020 } & \text { F026 } \\ \text { M017 } & \text { P031 } \\ \text { L028 } & \text { S047 }\end{array}$

A010

K005

\section{S Supporting Reasons}

33 Under 5000 Acres

11 Mining Impacts

22 Offers No Opportunities for Solitude

11 Offers No Opportunities for Recreation

11 No Supplemental Values

11 Intrusions Will Not Rehabilitate

11 No Supporting Reasons offered

I S FORM LETTERS \& PETITIONS

\section{SEQUENCE NUMBERS}

D029

T020

M029

P022 
FAVOR

Wilderness Study

I $\quad S$

$15 \quad 14$
OPPOSE

Wilderness Iesignation or

Wilderness Study Status

$\begin{array}{ll}\text { I } & \text { S } \\ 4 & 4\end{array}$

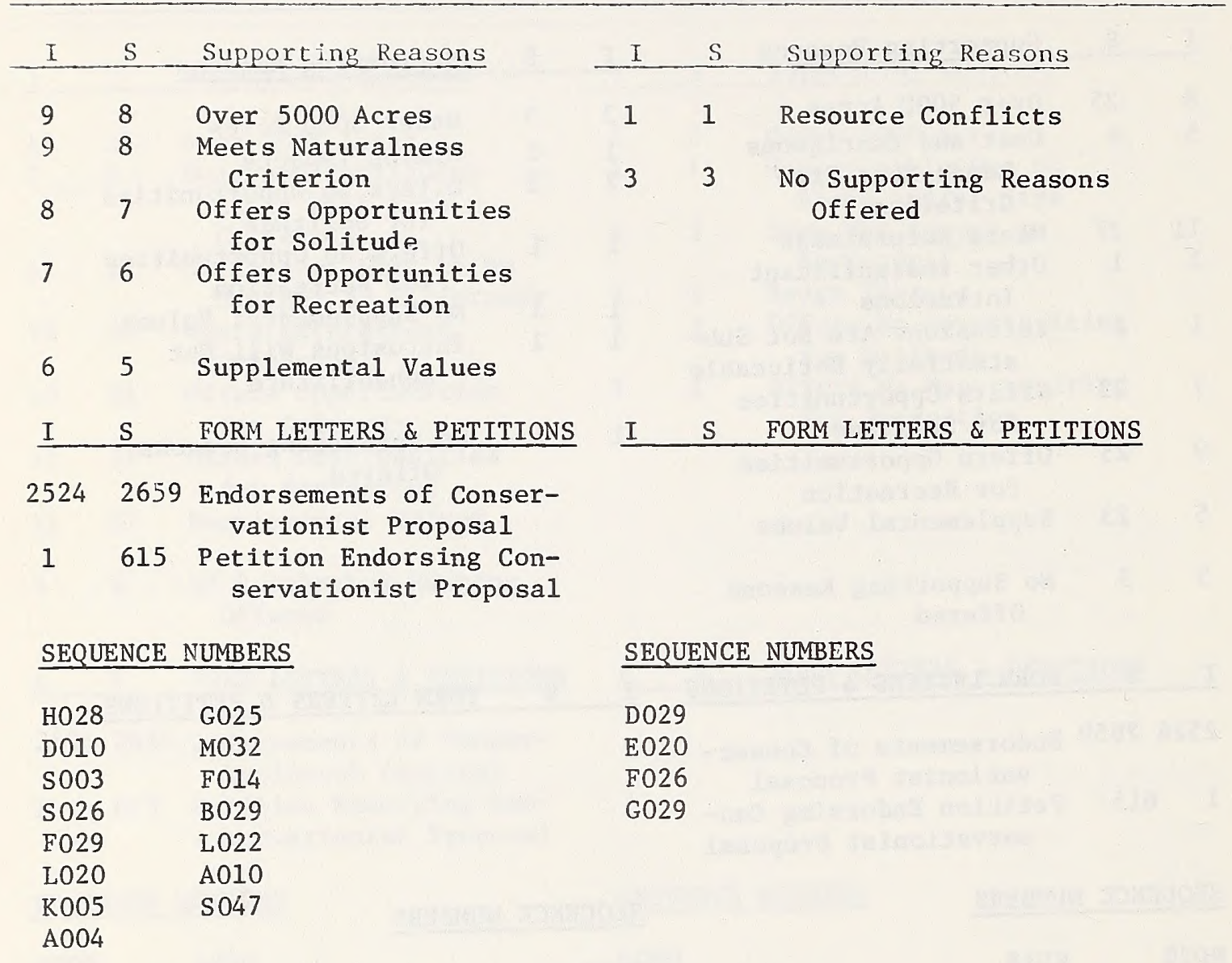


FAYOR

Wilderness Study

\section{OPPOSF}

Wilderness !esignation or Wilderness Study Status
I S

$16 \quad 15$
$1 \quad S$

44
I S S Supporting Reasons

1312 Over 5000 Acres

11 Unit and Contiguous Lands Meet Size Criterion

1211 Meets Naturalness Criterion

$11 \quad 10$ offers Opportunities for Solitude

7. 6 offers Opportunities for Recreation

76 Supplemental Values

44 No Supporting Reasons offered

I S FORM LETTERS \& PETITIONS

25242659 Endorsements of Conservationist Proposa1

1615 Petition Endorsing Conservationist Proposal

SEQUENCE NUMBERS

H028

D009

$\mathrm{Z} 003$

B026

F014

$\mathrm{S} 003 \quad \mathrm{~L} 022$

S035 F026

S036 S047

M017

K017

K005

I S S Supporting Reasons

11 Does Not Appear to Be Natural

11 Offers No Opportunities for Solitude

11 No Supplemental Values

11 Wilderness Study Comments

22 Resource Conflicts

11 Not Manageable as Wilderness

11 No Supporting Reasons offered

I S FORM LETTERS \& PETITIONS

SEQUENCE NUMBERS

D029

0005

G029

B046 
Unit Number: NM-020-056A Unit Name: Lumbre

FAVOR

Wilderness Study

$\begin{array}{ll}1 & \text { S } \\ 0 & 0\end{array}$

I S

Supporting Reasons

SEQUENCE NUMBERS

$$
\text { OPPOSE }
$$

Wilderness l)esignation or

Wilderness Study Status

$\begin{array}{ll}\mathrm{I} & \mathrm{S} \\ 3 & 3\end{array}$

33 No Supporting Reasons offered

\section{SEQUENCE NUMBERS}

D029

E020

F026 
DAAVOR

Wilderness Study

I $\mathrm{S}$

$0 \quad 0$

S Supporting Reasons

SEQUENCE NUMBERS
OPPOSE

Wilderness lesignation or

Wilderness Study Status

$\begin{array}{ll}I & S \\ 3 & 3\end{array}$

I S Supporting Reasons

33 No Supporting Reasons offered

\section{SEQUENCE NUMBERS}

D029

T020

F026 


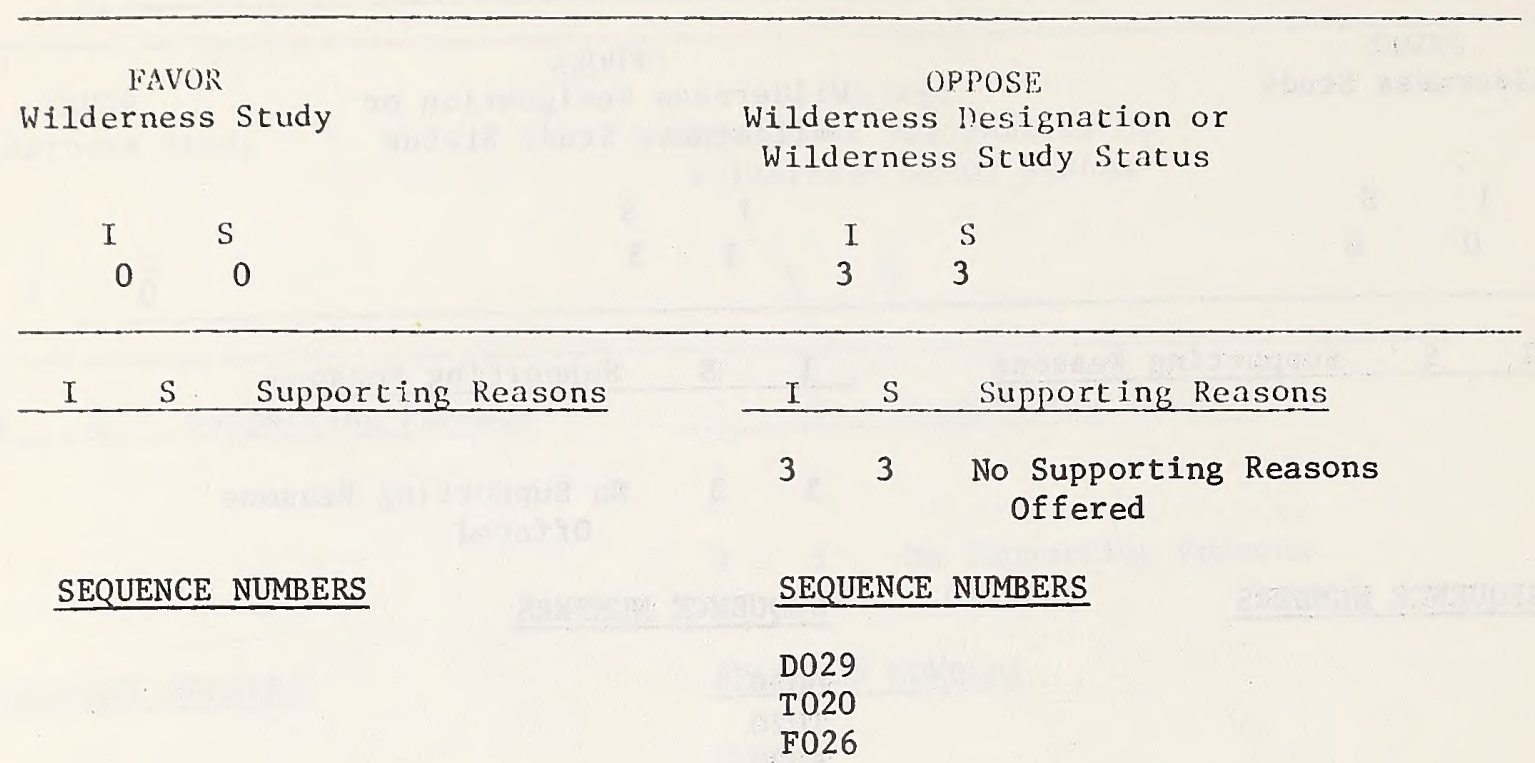


FAVOR

Wilderness Study
OPPOSE

Wilderness lesignation or

Wilderness Study Status

I S

$13 \quad 12$

I S

33

\begin{tabular}{|c|c|c|c|c|c|}
\hline I & $\mathrm{S}$ & Supporting Reasons & $I$ & $\mathrm{~S}$ & Supporting Reasons \\
\hline 1 & 1 & Meets Size Criterion & 2 & 2 & No Supporting Reasons \\
\hline 10 & 9 & Over 5000 Acres & & & offered \\
\hline 10 & 9 & Meets Naturalness Criter & & & \\
\hline 5 & 5 & $\begin{array}{l}\text { Offers Opportunities } \\
\text { for Solitude }\end{array}$ & 1 & 1 & Resource Conflicts \\
\hline 9 & 8 & $\begin{array}{l}\text { Offers Opportunities } \\
\text { for Recreation }\end{array}$ & & & \\
\hline 7 & 6 & Supplemental Values & & & \\
\hline 3 & 3 & $\begin{array}{l}\text { No Supporting Reasons } \\
\text { offered }\end{array}$ & & & \\
\hline$I$ & $\mathrm{~S}$ & FORM LETTERS \& PETITIONS & $\underline{I}$ & $\mathrm{~S}$ & FORM LETTERS \& PETITIONS \\
\hline
\end{tabular}

25242659 Endorsements of Conservationist Proposals

1615 Petition Endorsing Conservationist Proposal

\section{SEQUENCE NUMBERS}

H028 K013

D010 B026

S003 F014

S035 L022

L020 S047

M026 S035

K005

\section{SEQUENCE NUMBERS}

D029

T020

G029 


\section{Unit Number: NM-020-065 Unit Name: Offspring}

Fis

Wilderness Study

I S

$0 \quad 0$

I S S Supporting Reasons

SEQUENCE NUMBERS

\section{OPPOSE}

Wilderness Designation or

Wilderness Study Status

$1 \quad S$

11

I S S Supporting Reasons

11 No Supporting Reasons offered

SEQUENCE NUMBERS

T020 


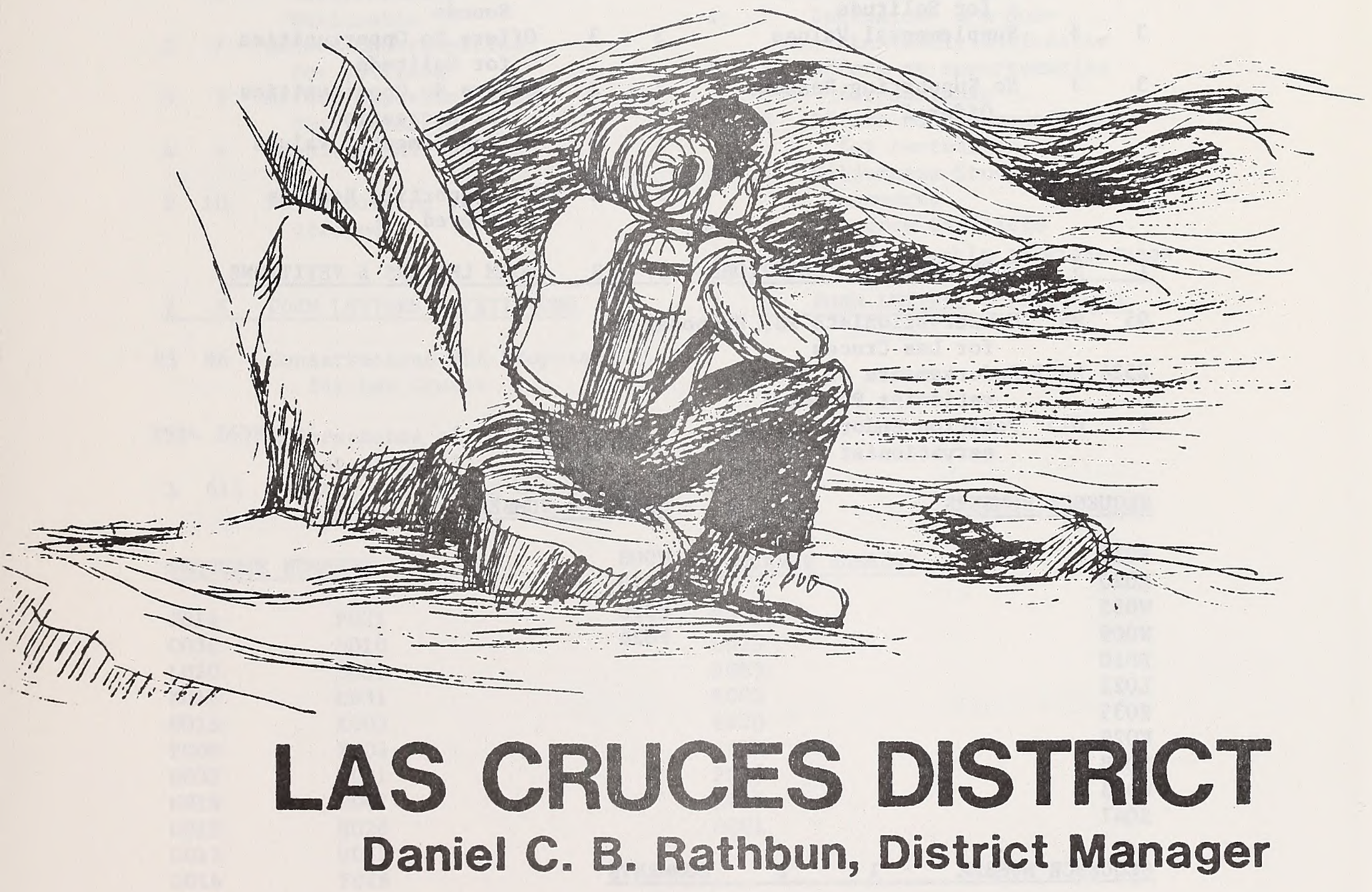


Unit Number: NM-030-001 Unit Name: Rodeo

FAVOR

Wilderness Study

I S

$10 \quad 10$
OPPOSE

Wilderness lesignation or

Wilderness Study Status

\begin{tabular}{|c|c|c|}
\hline I & $\underline{S}$ & Supporting Reasons \\
\hline 5 & 5 & Over 5000 Acres \\
\hline 3 & 3 & $\begin{array}{l}\text { Meets Naturalness } \\
\text { Criterion }\end{array}$ \\
\hline 1 & 1 & Range Impacts \\
\hline 2 & 2 & Other Intrusions \\
\hline 4 & 4 & $\begin{array}{l}\text { Offers Opportunities } \\
\text { for Solitude }\end{array}$ \\
\hline 3 & 3 & Supplemental Values \\
\hline 3 & 3 & $\begin{array}{l}\text { No Supporting Reasons } \\
\text { offered }\end{array}$ \\
\hline
\end{tabular}

I S FORM LETTERS \& PETITIONS

\begin{tabular}{|c|c|c|}
\hline$I$ & $S$ & Supporting Reasons \\
\hline 1 & 1 & $\begin{array}{l}\text { Does Not Meet Size } \\
\text { Criterion }\end{array}$ \\
\hline 1 & 1 & $\begin{array}{l}\text { Does Not Appear to Be } \\
\text { Natural }\end{array}$ \\
\hline 2 & 2 & Range Impacts \\
\hline 1 & 1 & $\begin{array}{l}\text { Outside Sights and } \\
\text { Sounds }\end{array}$ \\
\hline 3 & 3 & $\begin{array}{l}\text { Offers No Opportunities } \\
\text { for Solitude }\end{array}$ \\
\hline 2 & 2 & $\begin{array}{l}\text { Offers No Opportunities } \\
\text { for Recreation }\end{array}$ \\
\hline 1 & 1 & No Supplemental Values \\
\hline 1 & 1 & $\begin{array}{l}\text { No Supporting Reasons } \\
\text { offered }\end{array}$ \\
\hline
\end{tabular}

\section{Conservationists WSA Proposal for Las Cruces \\ 25242659 Endorsements of Conser- vationist Proposal \\ 1615 Petition Endorsing Con- servationist Proposal}

\section{SEQUENCE NUMBERS}

F014
L020 L001
W033
W009
D010
L022
S035
K029
H028
W033
S047

\section{SEQUENCE NUMBERS}

W008

D029

E020

F026

\section{SEQUENCE NUMBER $\quad$ I $\quad S \quad$ COMMENTS}

$\begin{array}{lllll}\text { W015 } & 1 & 1 & \text { Area Should Be Reinventoried } \\ \text { P021 } & 1 & 1 & 11 & " 1 \\ \text { M031 } & 1 & 1 & 1 " & \text { " } \\ \text { E018 } & 1 & 1 & 1 " & \end{array}$


Favor Wilderness Study
Oppose Wilderness Designation or Wilderness Study Status

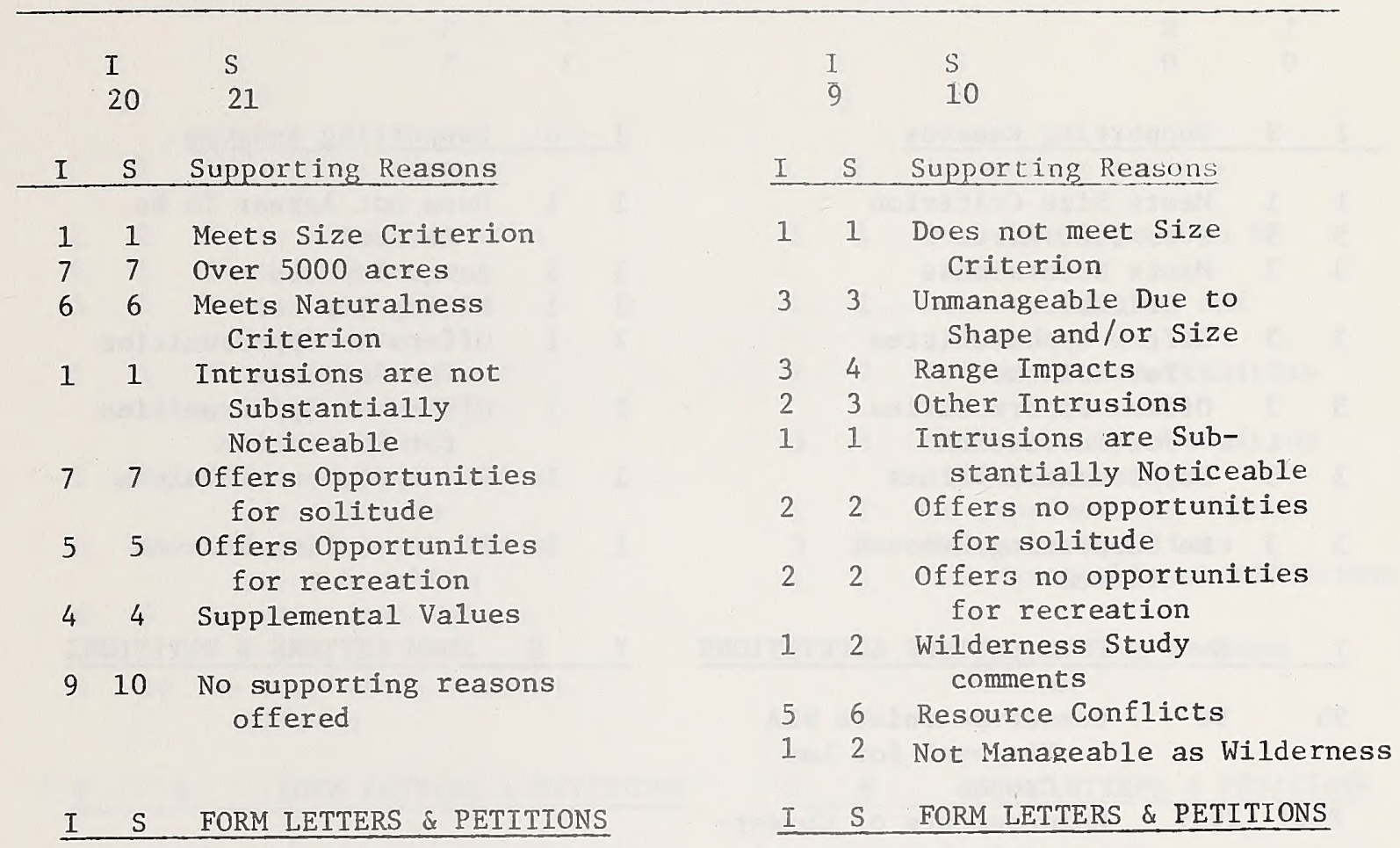

9596 Conservations WSA Proposal for Las Cruces

25242659 Endorsements of Conservationist proposal

1615 Petition endorsing conservationist proposal

\section{SEQUENCE NUMBERS}

$\begin{array}{ll}\text { F014 } & \text { P021 } \\ \text { C030 } & \text { D010 } \\ \text { L020 } & \text { S035 } \\ \text { K017 } & \text { M031 } \\ \text { W015 } & \text { K005 } \\ \text { P006 } & \text { Z003 } \\ \text { W033 } & \text { L001 } \\ \text { K018 } & \text { S047 } \\ \text { C015 } & \text { H028 } \\ \text { C012 } & \text { W033 } \\ \text { C016 } & \text { F026 }\end{array}$

\section{SEQUENCE NUMBERS}

K023

D029

S065

K005

E020

J011

P026

K030

0001 


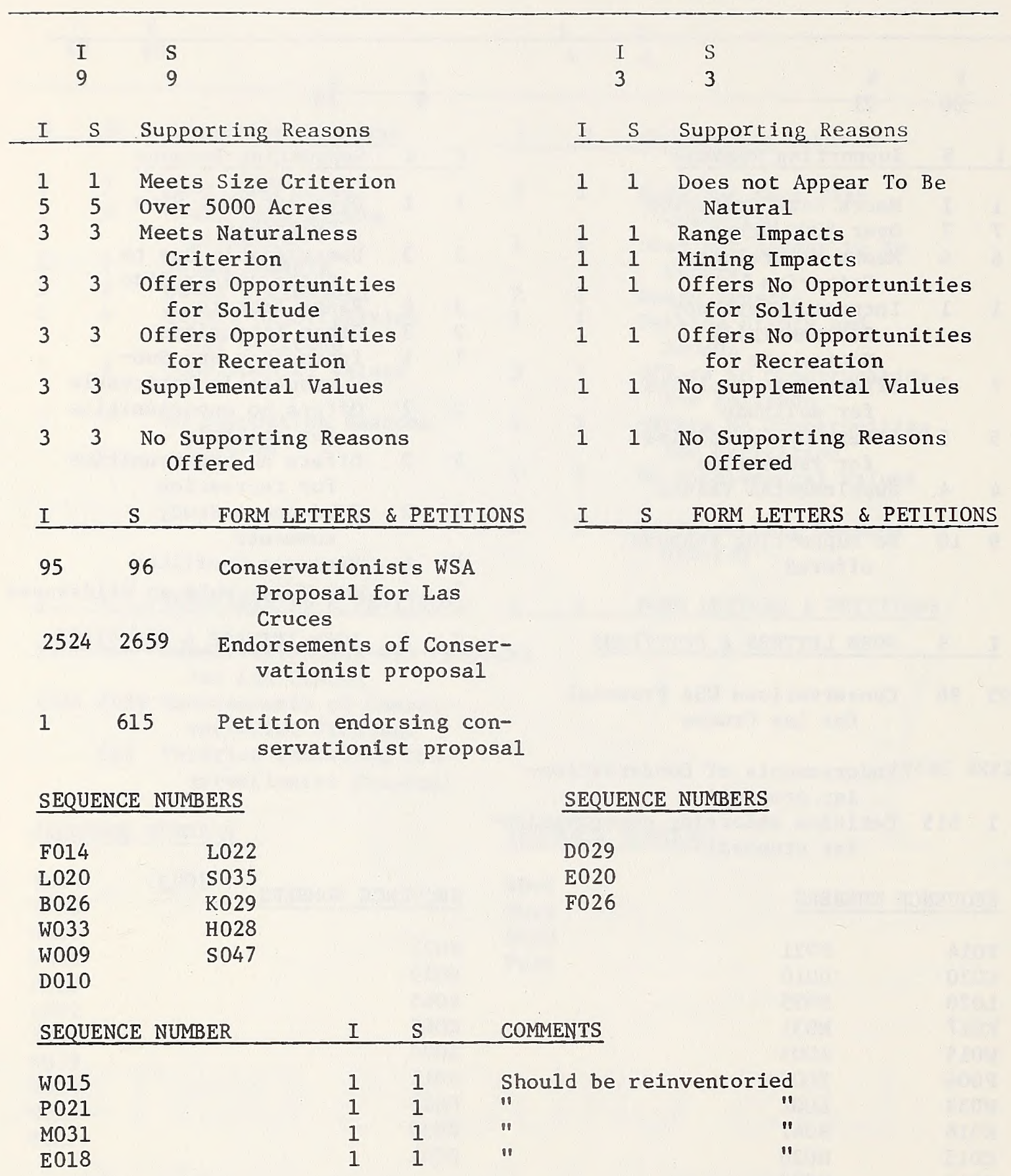




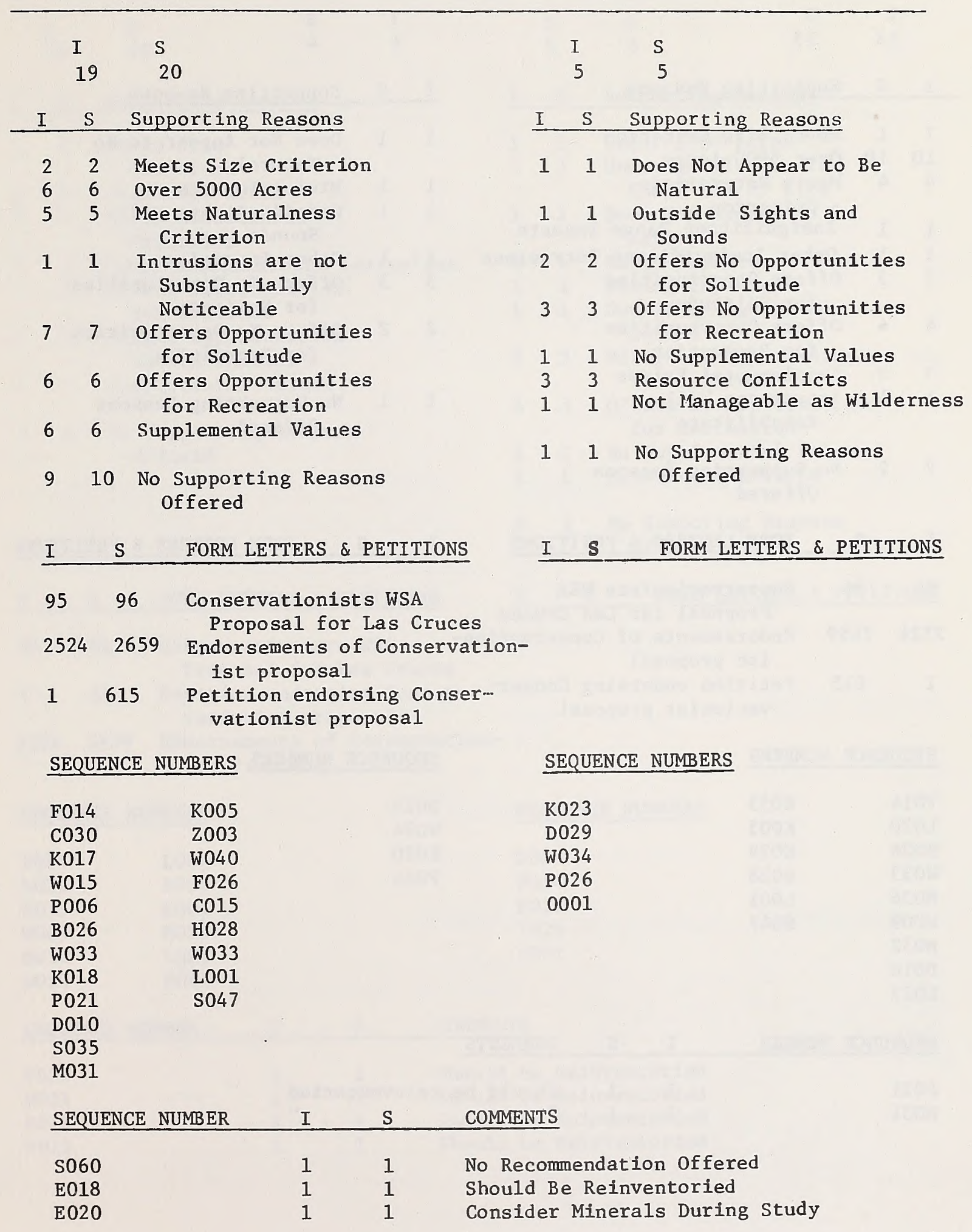




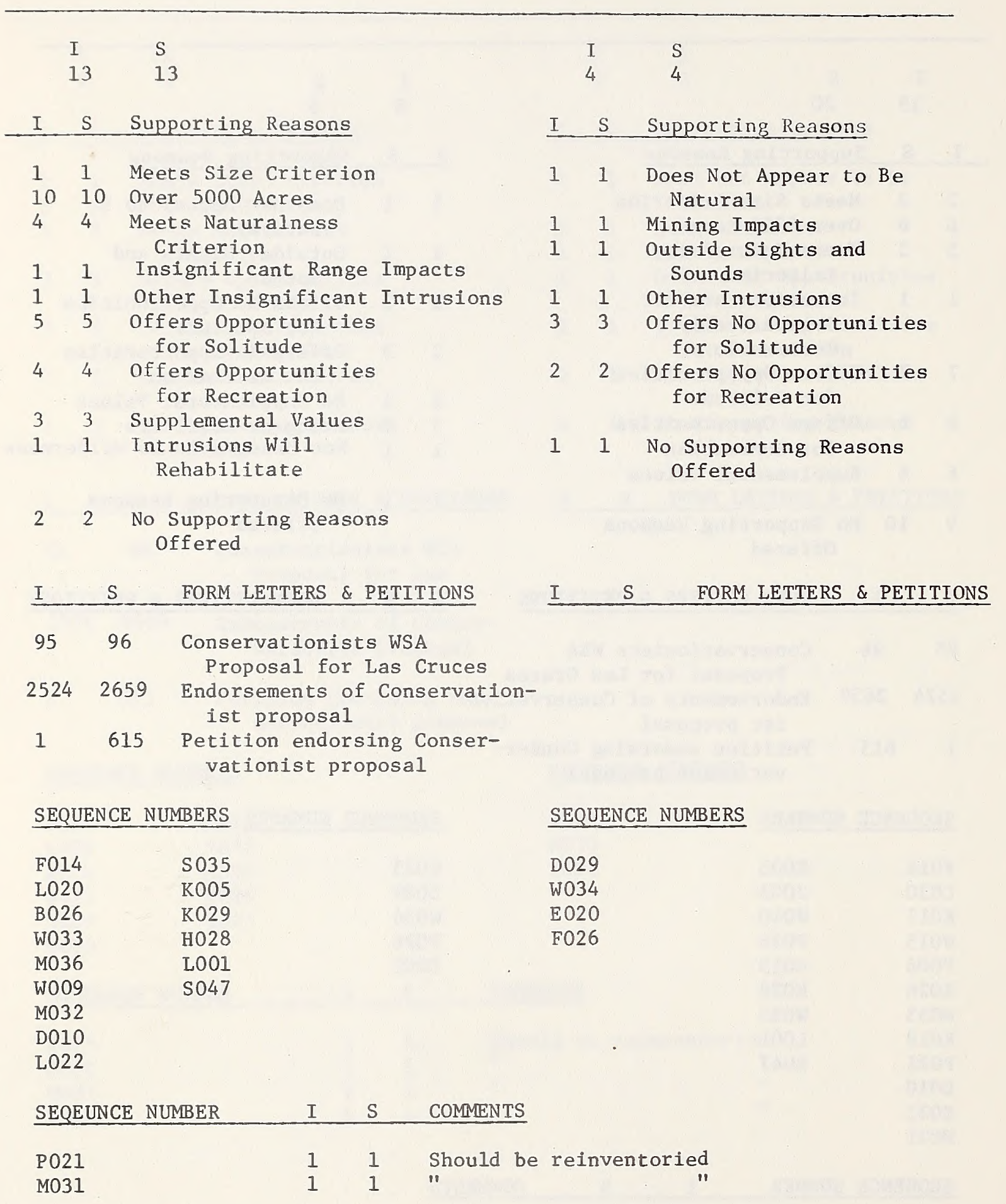


Favor Wilderness Study
Oppose Wilderness Designation or Wilderness Study Status

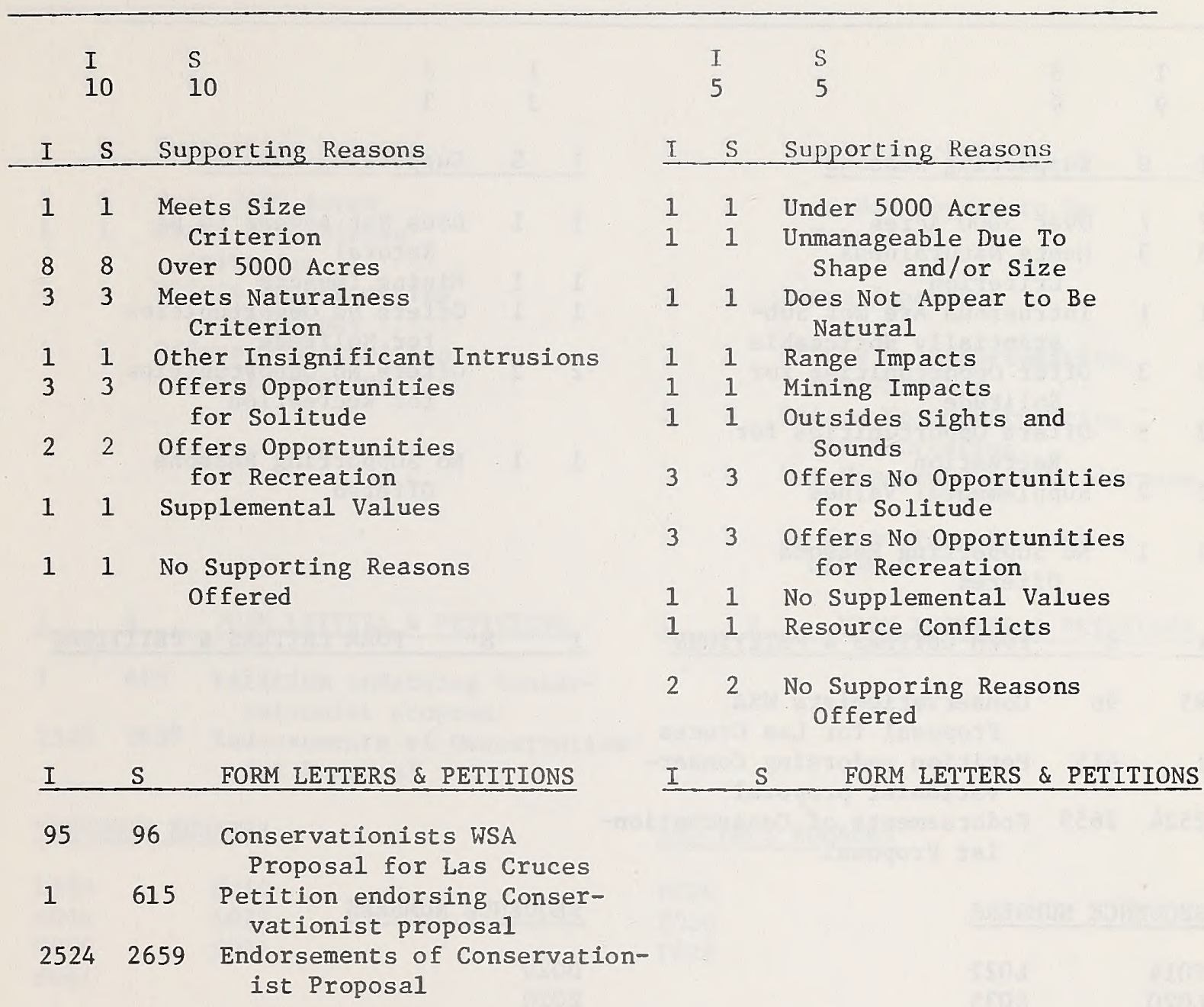

\section{SEQUENCE NUMBERS}

$\begin{array}{ll}\text { F014 } & \text { L022 } \\ \text { L020 } & \text { S035 } \\ \text { W033 } & \text { K005 } \\ \text { W009 } & \text { H028 } \\ \text { M032 } & \text { L001 } \\ \text { D010 } & \text { S047 }\end{array}$

\section{SEQUENCE NUMBERS}

D029

W034

E020

F026

0001

\section{\begin{tabular}{llll} 
SEQUENCE NUMBER & I & $S$ & COMMENTS \\
\hline
\end{tabular}}

$\begin{array}{llll}\text { P021 } & 1 & 1 & \text { Should be Reinventoried } \\ \text { M031 } & 1 & 1 & \text { Should be Reinventoried } \\ \text { E018 } & 1 & 1 & \text { Should be Reinventoried } \\ \text { W015 } & 1 & 1 & \text { Should be Reinventoried }\end{array}$




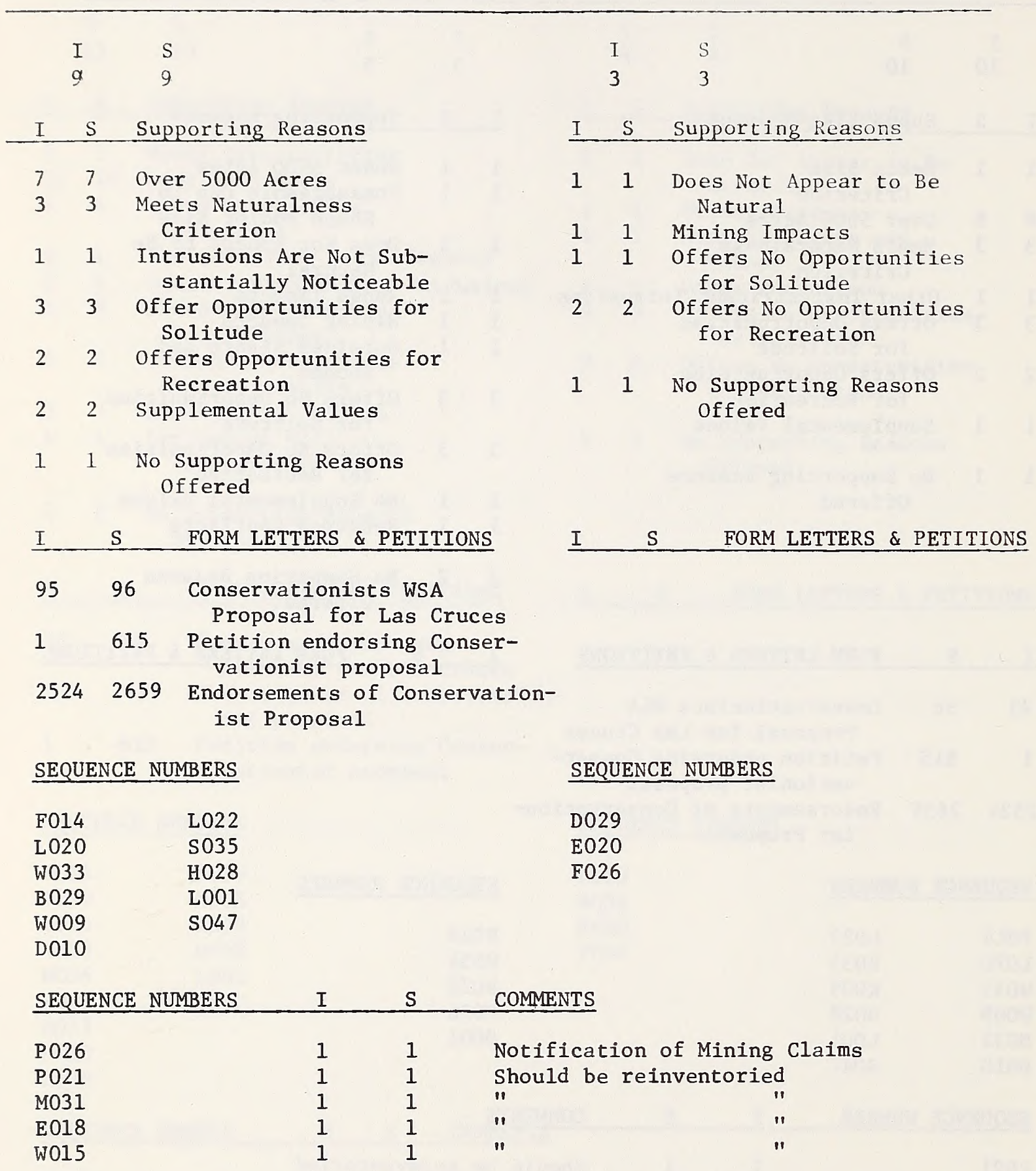




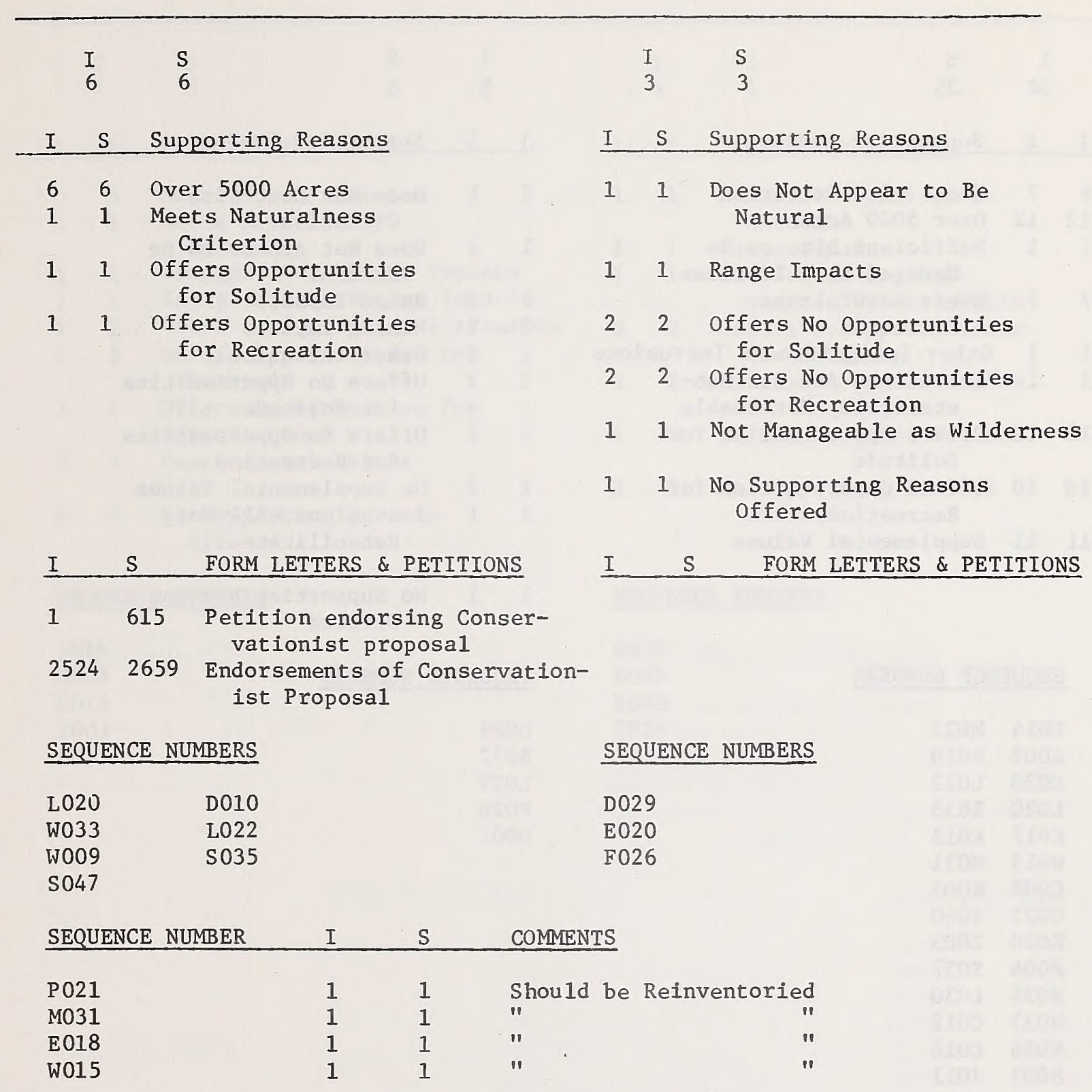




\begin{tabular}{|c|c|c|}
\hline & $\begin{array}{l}I \\
34\end{array}$ & $\begin{array}{l}S \\
35\end{array}$ \\
\hline I & $\mathrm{S}$ & Supporting Reasons \\
\hline 6 & 7 & Meets Size Criterion \\
\hline 12 & 12 & Over 5000 Acres \\
\hline 1 & 1 & $\begin{array}{l}\text { Sufficient Size to Be } \\
\text { Managed as Wilderness }\end{array}$ \\
\hline 7 & 7 & $\begin{array}{l}\text { Meets Naturalness } \\
\text { Criterion }\end{array}$ \\
\hline 1 & 1 & Other Insignificant Intruston \\
\hline 1 & 1 & $\begin{array}{l}\text { Intrusions Are Not Sub- } \\
\text { stantially Noticeable }\end{array}$ \\
\hline 12 & 12 & $\begin{array}{l}\text { Offers Opportunities for } \\
\text { Solitude }\end{array}$ \\
\hline 10 & 10 & $\begin{array}{l}\text { Offers Opportunities for } \\
\text { Recreation }\end{array}$ \\
\hline 11 & 11 & Supplemental Values \\
\hline
\end{tabular}

\section{SEQUENCE NUMBERS}

$\begin{array}{ll}\text { F014 } & \text { M023 } \\ \text { A002 } & \text { D010 } \\ \text { C030 } & \text { L022 } \\ \text { L020 } & \text { S035 } \\ \text { K017 } & \text { K013 } \\ \text { W015 } & \text { M031 } \\ \text { C002 } & \text { K005 } \\ \text { G025 } & \text { S060 } \\ \text { K020 } & \text { Z003 } \\ \text { P006 } & \text { S057 } \\ \text { B026 } & \text { L030 } \\ \text { W033 } & \text { C012 } \\ \text { S026 } & \text { C016 } \\ \text { S003 } & \text { J011 } \\ \text { B001 } & \text { H028 } \\ \text { P021 } & \text { W033 } \\ \text { W009 } & \text { L001 } \\ & \text { S047 }\end{array}$

$\underline{I}$ S

Conservationists WSA

Proposal for Las Cruces

1615 Petition endorsing Conservationist Proposal

25242659 Endorsements of Conservationist Proposal

\section{SEQUENCE NUMBER}

F026

D004

D021

I

I $\quad S$

S COMMENTS

11

11

$\begin{array}{ll}I & S \\ 5 & 5\end{array}$

I S Supporting Reasons

11 Does Not Meet Size Criterion

11 Does Not Appear to Be Natural

33 Range Impacts

22 Mining Impacts

12 Other Intrusions

22 Offers No Opportunities for Solitude

22 Offers No Opportunities for Recreation

22 No Supplemental Values

11 Intrusions Will Not Rehabilitate

11 No Supporting Reasons offered

\section{SEQUENCE NUMBERS}

D029

B032

L029

P026

D001

\section{S FORM LETTERS \& PETITIONS}

River periodically floods and needs to be worked

Concerned about access to deeded land maps do not ackowledge P. Inholding or Cottonwood Springs Access Road Notification of Mining Claims 


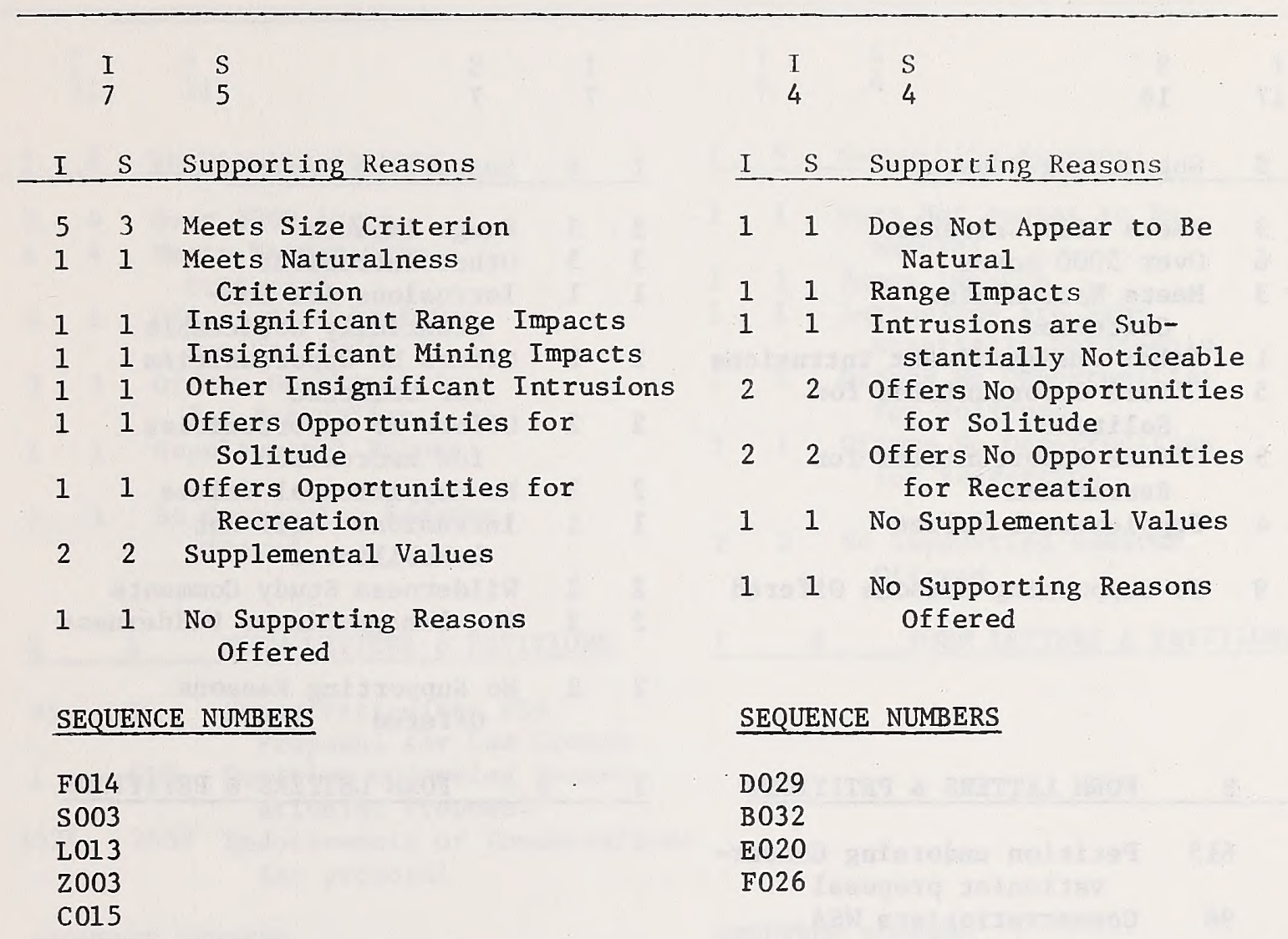




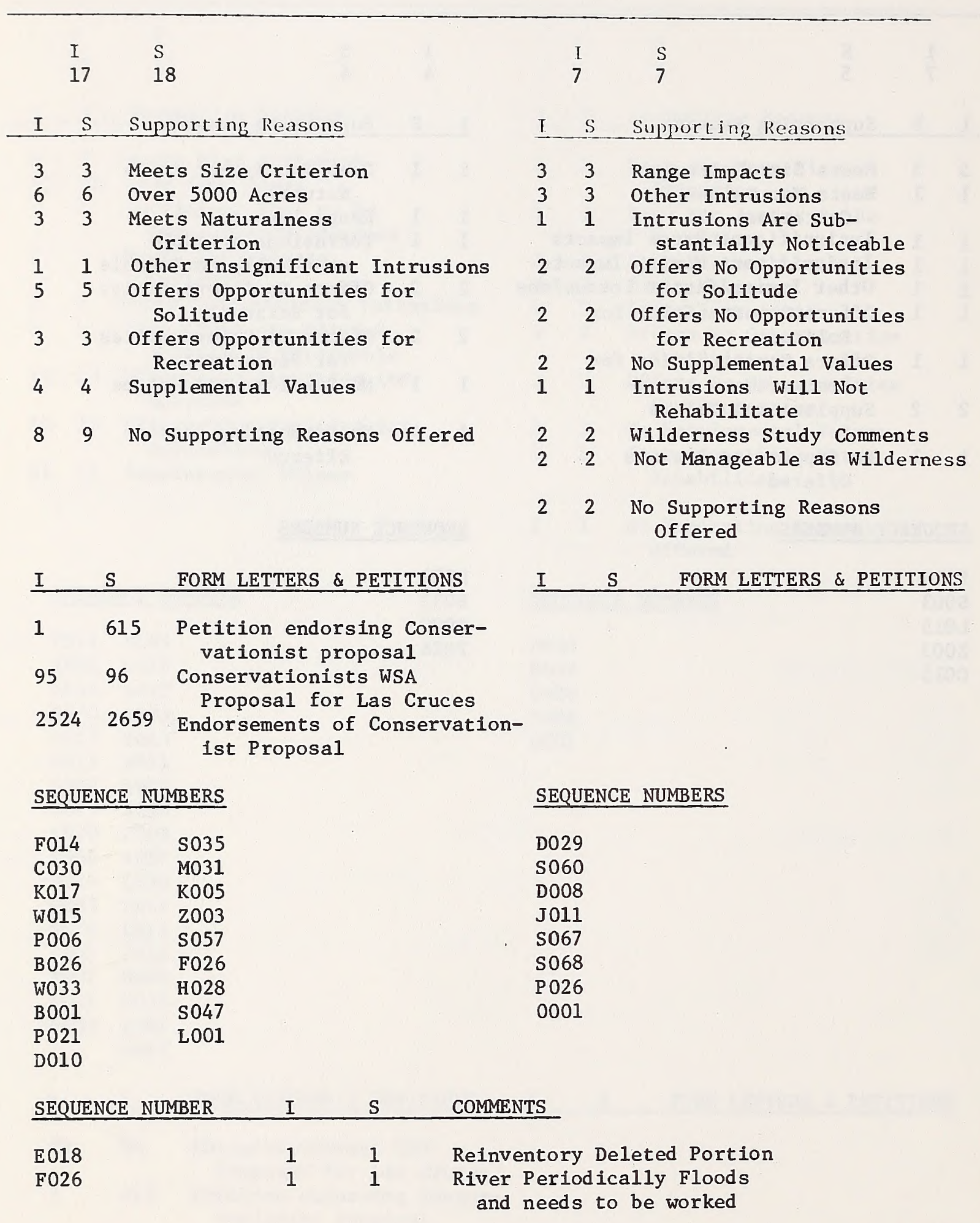




I $\quad$ S

$11 \quad 11$

\section{S Supporting Reasons}

\section{Over 5000 Acres \\ 44 Meets Naturalness \\ Criterion}

44 offers Opportunities

for solitude

33 offers Opportunities

for Recreation

1 . 1 Supplemental Values

11 No Supporting Reasons offered

\section{S FORM LETTERS \& PETITIONS}

\section{Conservationists WSA \\ 1615 Petition endorsing Conser- \\ 250 ationist Proposal}

25242659 Endorsements of Conservationist proposal

\section{SEQUENCE NUMBERS}

$\begin{array}{ll}\text { F014 } & \text { D010 } \\ \text { H028 } & \text { L022 } \\ \text { L020 } & \text { S035 } \\ \text { W033 } & \text { K005 } \\ \text { W009 } & \text { Z003 } \\ \text { M023 } & \text { L001 } \\ & \text { S047 }\end{array}$

SEQUENCE NUMBERS

D029

E020

J011

F026

\section{\begin{tabular}{llll} 
SEQUENCE NUMBER & I & S & COMMENTS \\
\hline
\end{tabular}}

$\begin{array}{lllll}\text { W015 } & 1 & 1 & \text { Should be Reinventoried } \\ \text { P021 } & 1 & 1 & " 1 & " 1 \\ \text { M031 } & 1 & 1 & " 1 & " \\ \text { E018 } & 1 & 1 & " 1\end{array}$




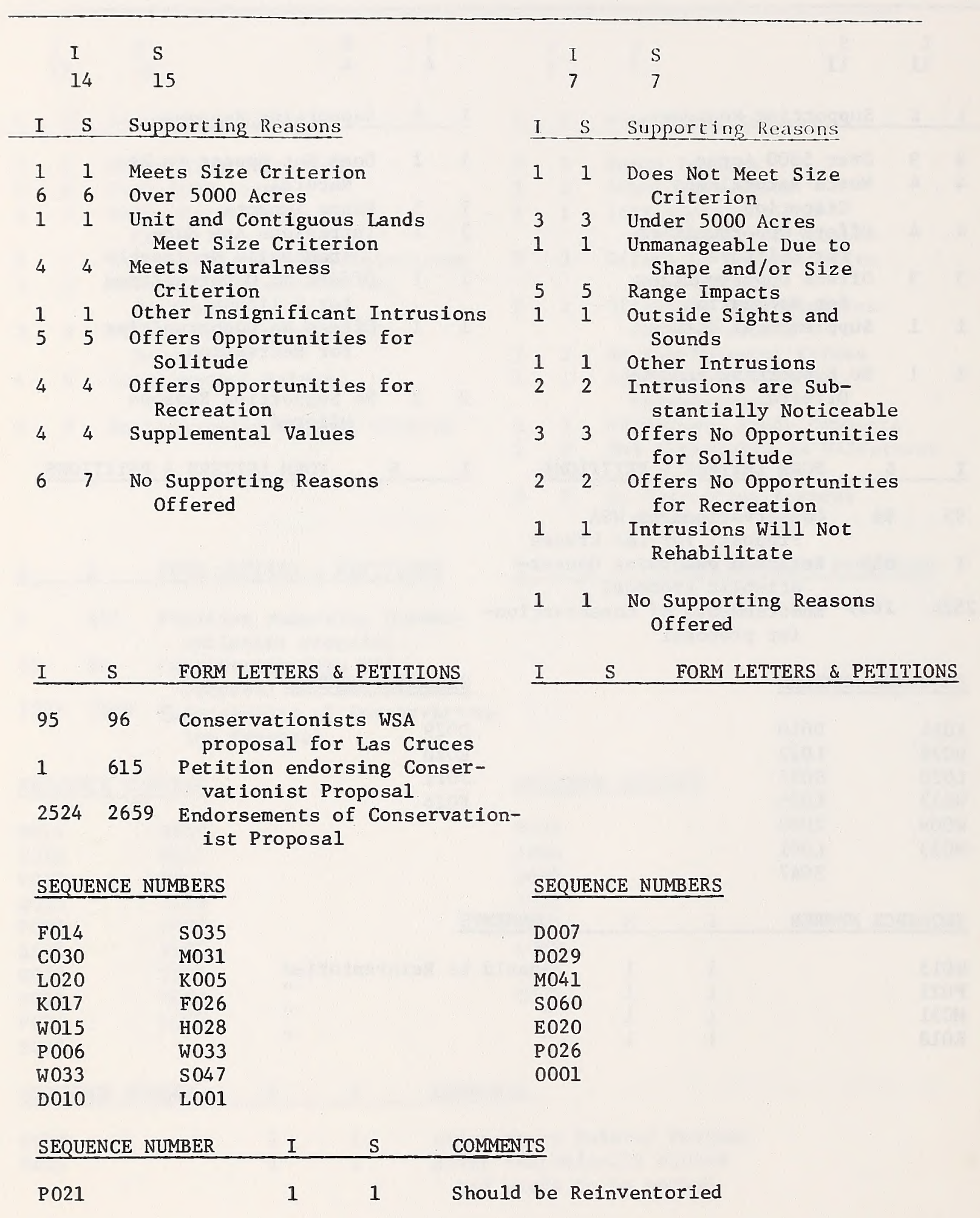


I

S

I S Supporting Reasons

SEQUENCE NUMBERS

SEQUENCE NUMERS

F026

$\begin{array}{llll}\text { SEQUENCE NUMBER } & \text { I } & \text { S } & \text { COMMENTS } \\ \text { W015 } & 1 & 1 & \text { Inadequate Inventory } \\ \text { E018 } & 1 & 1 & \text { Should Be Reinventoried } \\ \text { P021 } & 1 & 1 & \text { " } \\ \text { W015 } & 1 & 1 & \text { Inadequate Inventory } \\ \text { M031 } & 1 & 1 & \text { Should Be Reinventoried }\end{array}$




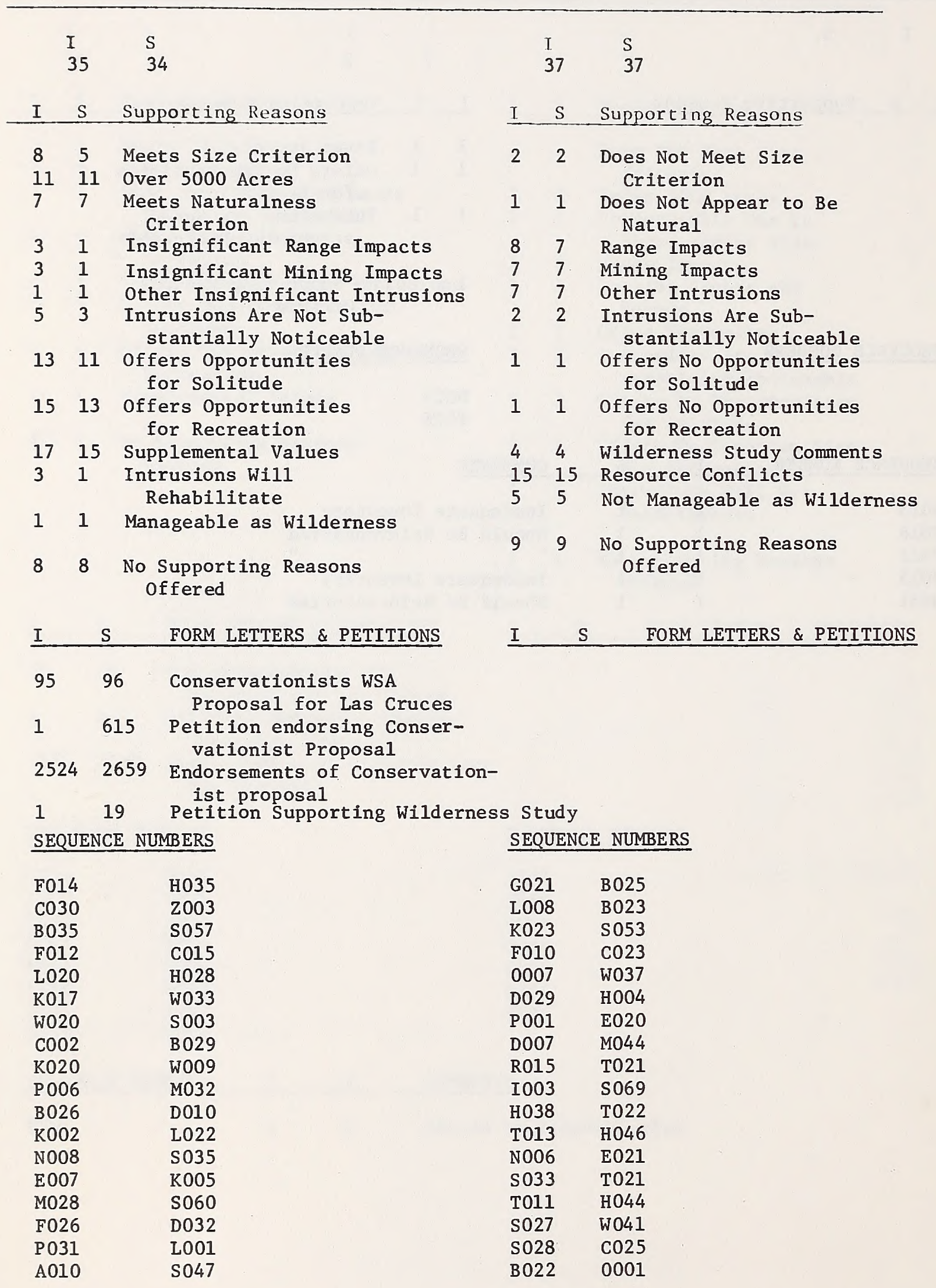




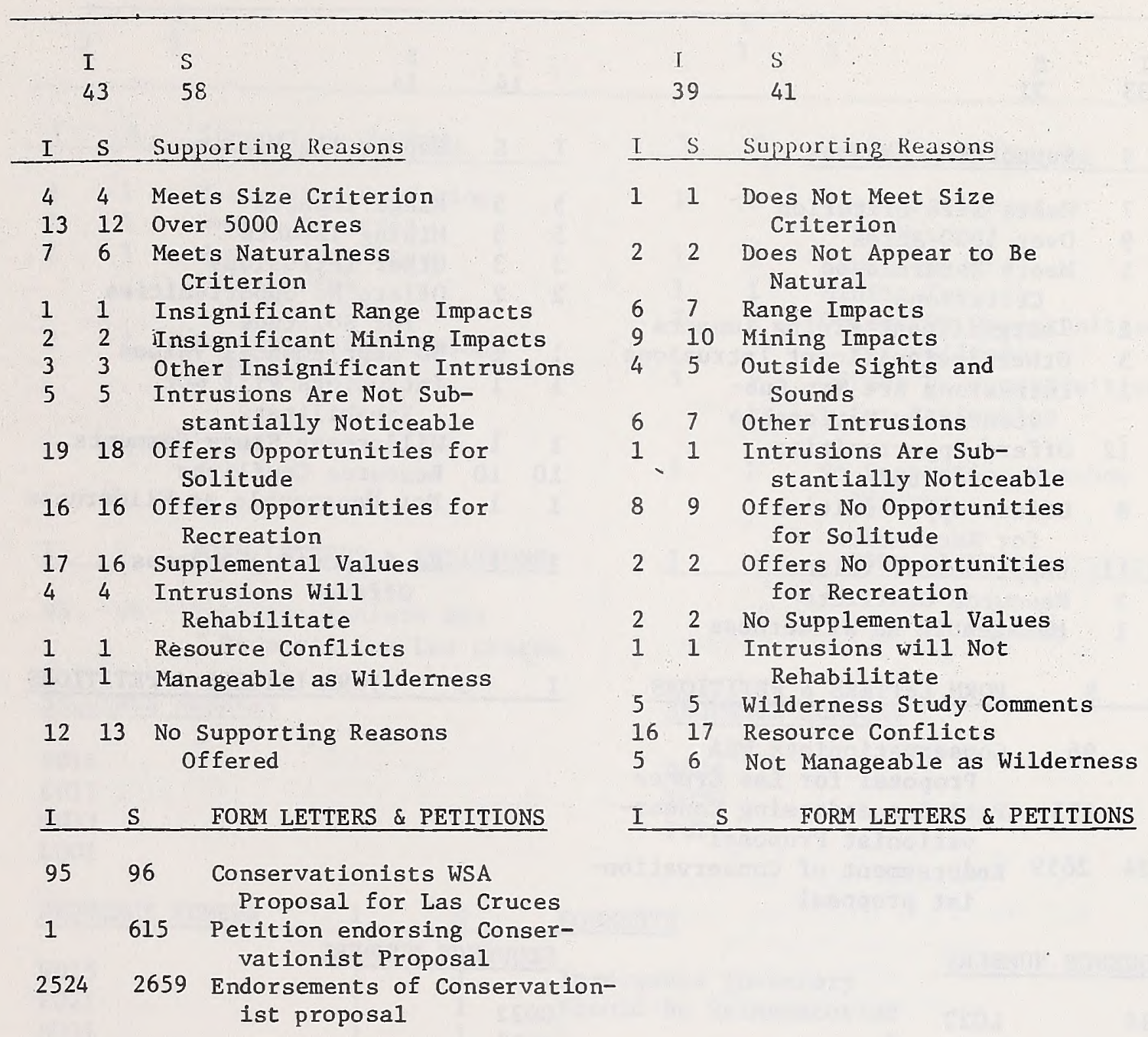

\section{SEQUENCE NUMBERS}

$\begin{array}{ll}\text { F014 } & \text { S007 } \\ \text { C030 } & \text { S026 } \\ \text { B035 } & \text { M028 } \\ \text { F012 } & \text { M040 } \\ \text { L020 } & \text { E019 } \\ \text { L011 } & \text { S003 } \\ \text { K017 } & \text { B 001 } \\ \text { W020 } & \text { P021 } \\ \text { W019 } & \text { D010 } \\ \text { W015 } & \text { L022 } \\ \text { C002 } & \text { S035 } \\ \text { J003 } & \text { K013 } \\ \text { G025 } & \text { M031 } \\ \text { T001 } & \text { K005 } \\ \text { P006 } & \text { S060 } \\ \text { K002 } & \text { E018 } \\ \text { W033 } & \text { S057 } \\ \text { K019 } & \text { A010 } \\ \text { N008 } & \text { C015 } \\ \text { H020 } & \text { S } 047 \\ \text { P031 } & \text { L001 }\end{array}$

\section{SEQUENCE NUMBERS}

$\begin{array}{ll}\text { G022 } & \text { T022 } \\ \text { K023 } & \text { I004 } \\ \text { F010 } & \text { H046 } \\ \text { O007 } & \text { E021 } \\ \text { D029 } & \text { T021 } \\ \text { H038 } & \text { M014 } \\ \text { N006 } & \text { M048 } \\ \text { T011 } & \text { D007 } \\ \text { S033 } & \text { R015 } \\ \text { S027 } & \text { I003 } \\ \text { S028 } & \text { G024 } \\ \text { B022 } & \text { C023 } \\ \text { B025 } & \text { K019 } \\ \text { B023 } & \text { G027 } \\ \text { S053 } & \text { W041 } \\ \text { E020 } & \text { C015 } \\ \text { I004 } & 0001 \\ \text { P030 } & \text { S069 } \\ \text { M044 } & \\ \text { T021 } & \\ \text { M046 } & \end{array}$




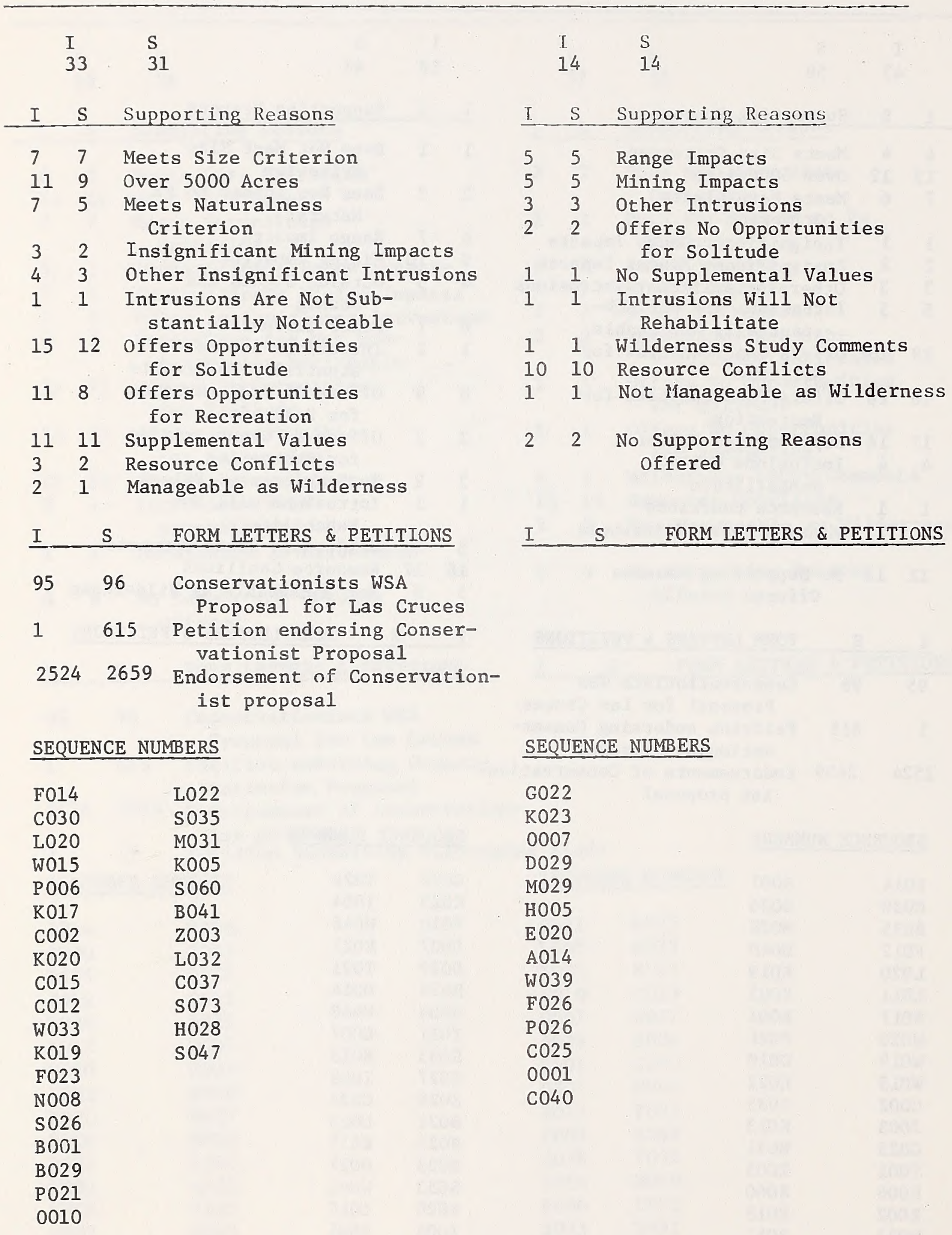


Unit Number: NM-030-036 Unit Name: Sierra Ricas

Favor

Wilderness Study
Oppose

Wilderness Designation ox Wilderness Study Status

I S

33

$\begin{array}{ll}1 & \text { S } \\ 3 & 3\end{array}$

\begin{tabular}{|c|c|c|}
\hline$I$ & $\mathrm{~S}$ & Supporting Reasons \\
\hline 1 & 1 & Meets Size Criterion \\
\hline 1 & 1 & Over 5000 Acres \\
\hline 1 & 1 & $\begin{array}{l}\text { Meets Naturalness } \\
\text { Criterion }\end{array}$ \\
\hline 2 & 2 & $\begin{array}{l}\text { No Supporting Reasons } \\
\text { offered }\end{array}$ \\
\hline I & $\mathrm{S}$ & FORM LETTERS \& PETITIONS \\
\hline 95 & 96 & $\begin{array}{l}\text { Conservationists WSA } \\
\text { Proposal for Las Cruces }\end{array}$ \\
\hline
\end{tabular}

SEQUENCE NUMBERS

SEQUENCE NUMBERS

F014

D029

$\mathrm{K} 017$

E020

W033

F026

L001

SEQUENCE NUMBER

I

W015

$\mathrm{P} 021$

M031

E018

\begin{tabular}{|c|c|c|}
\hline$I$ & $\mathrm{~S}$ & Supporting Reasons \\
\hline 1 & 1 & $\begin{array}{l}\text { Does Not Appear to } \\
\text { Be Natural }\end{array}$ \\
\hline 1 & 1 & Range Impacts \\
\hline 1 & 1 & Mining Impacts \\
\hline 2 & 2 & $\begin{array}{l}\text { Offers No Opportunities } \\
\text { for Solitude }\end{array}$ \\
\hline 1 & 1 & $\begin{array}{l}\text { Offers No Opportunities } \\
\text { for Recreation }\end{array}$ \\
\hline 1 & 1 & $\begin{array}{l}\text { No Supporting Reasons } \\
\text { Offered }\end{array}$ \\
\hline$I$ & $\mathrm{~S}$ & FORM LETTERS \& PETITIONS \\
\hline
\end{tabular}


Unit Number: NM-030-038 Unit Name: Alamo Hueco Mountains

Favor

Wilderness Study

I S

$22 \quad 22$
Oppose

Wilderness Designation or

Wilderness Study Status

I $\mathrm{S}$

$14 \quad 14$

\begin{tabular}{|c|c|c|}
\hline I & S & Supporting Reasons \\
\hline 1 & 1 & Meets Size Criterion \\
\hline 10 & 10 & Over 5000 Acres \\
\hline 5 & 5 & $\begin{array}{l}\text { Meets Naturalness } \\
\text { Criterion }\end{array}$ \\
\hline 3 & 3 & $\begin{array}{l}\text { Other Insignificant } \\
\text { Intrusions }\end{array}$ \\
\hline 2 & 2 & $\begin{array}{l}\text { Intrusions Are Not Sub- } \\
\text { stantially Noticeable }\end{array}$ \\
\hline 11 & 11 & $\begin{array}{l}\text { Offers Opportunities } \\
\text { for Solitude }\end{array}$ \\
\hline 8 & 8 & $\begin{array}{l}\text { Offers Opportunities } \\
\text { for Recreation }\end{array}$ \\
\hline 13 & 13 & Supplemental Values \\
\hline 1 & 1 & Resource Conflicts \\
\hline 2 & 2 & Manageable as Wilderness \\
\hline 5 & 6 & $\begin{array}{l}\text { No Supporting Reasons } \\
\text { offered }\end{array}$ \\
\hline I & S & FORM LETTERS \& PETITIONS \\
\hline 95 & 96 & $\begin{array}{l}\text { Conservationists WSA } \\
\text { Proposal for Las Cruces }\end{array}$ \\
\hline 1 & 615 & $\begin{array}{l}\text { Petition endorsing Conser- } \\
\text { vationist Proposal }\end{array}$ \\
\hline
\end{tabular}

25242659 Endorsements of Conservationist Proposal

\section{SEQUENCE NUMBERS}

$\begin{array}{ll}\text { F014 } & \text { D010 } \\ \text { C030 } & \text { L022 } \\ \text { L020 } & \text { S035 } \\ \text { C002 } & \text { K005 } \\ \text { S026 } & \text { B041 } \\ \text { C002 } & \text { Z003 } \\ \text { K020 } & \text { F026 } \\ \text { P006 } & \text { C015 } \\ \text { W033 } & \text { H028 } \\ \text { K019 } & \text { W033 } \\ \text { F023 } & \text { S047 } \\ \text { B001 } & \text { L001 }\end{array}$

\begin{tabular}{|c|c|c|}
\hline I & $\mathrm{S}$ & Supporting Reasons \\
\hline 4 & 4 & Unmanageable Due To \\
\hline & & Shape and/or Size \\
\hline 1 & 1 & $\begin{array}{l}\text { Does Not Appear to Be } \\
\text { Natural }\end{array}$ \\
\hline 5 & 5 & Range Impacts \\
\hline 2 & 2 & $\begin{array}{l}\text { Outside Sights and } \\
\text { Sounds }\end{array}$ \\
\hline 2 & 2 & Other Intrusions \\
\hline 3 & 3 & $\begin{array}{l}\text { Offers No Opportunities } \\
\text { for Solitude }\end{array}$ \\
\hline 4 & 4 & $\begin{array}{l}\text { Offers No Opportunities } \\
\text { for Recreation }\end{array}$ \\
\hline 2 & 2 & Supplemental Values \\
\hline 1 & 1 & Wilderness Study Comments \\
\hline 6 & 6 & Resource Conflicts \\
\hline 2 & 2 & Not Manageable as Wilderness \\
\hline 4 & 4 & $\begin{array}{l}\text { No Supporting Reasons } \\
\text { Offered }\end{array}$ \\
\hline I & $\mathrm{S}$ & FORM LETTERS \& PETITIONS \\
\hline
\end{tabular}

SEQUENCE NUMBERS

G022 0001

$\mathrm{K} 023 \quad \mathrm{C} 040$

0006

D029

M029

H005

S060

E020

A014

W039

C037

P026 
FAVOR

Wilderness Study

\section{OPPOSE}

Wilderness Designation or Wilderness Study Status
I S

$11 \quad 12$
I $\quad S$

\begin{tabular}{|c|c|c|c|c|c|}
\hline I & $\mathrm{S}$ & Supporting Reasons & $I$ & $S$ & Supporting Reasons \\
\hline 2 & 2 & Meets Size Criterion & $\overline{2}$ & 2 & Does Not Appear to $\mathrm{Be}$ \\
\hline 8 & 9 & Over 5000 Acres & & & Natural \\
\hline 2 & 2 & $\begin{array}{l}\text { Meets Naturalness } \\
\text { Criterion }\end{array}$ & $\begin{array}{l}15 \\
6\end{array}$ & $\begin{array}{l}15 \\
6\end{array}$ & $\begin{array}{l}\text { Range Impacts } \\
\text { Mining Impacts }\end{array}$ \\
\hline 1 & 1 & $\begin{array}{l}\text { Other Insignificant } \\
\text { Intrusions }\end{array}$ & $\begin{array}{l}10 \\
1\end{array}$ & $\begin{array}{l}10 \\
1\end{array}$ & $\begin{array}{l}\text { Other Intrusions } \\
\text { Intrusions Are Sub- }\end{array}$ \\
\hline 3 & 3 & $\begin{array}{l}\text { Intrusions Are Not Sub- } \\
\text { stantially Noticeable }\end{array}$ & 4 & 4 & $\begin{array}{l}\text { stantially Noticeable } \\
\text { offers No Opportunities }\end{array}$ \\
\hline 6 & 7 & $\begin{array}{l}\text { Offers Opportunities } \\
\text { for Solitude }\end{array}$ & 4 & 4 & $\begin{array}{l}\text { for Solitude } \\
\text { Offers No Opportunities. }\end{array}$ \\
\hline 5 & 6 & $\begin{array}{l}\text { Offers Opportunities } \\
\text { for Recreation }\end{array}$ & 1 & 1 & $\begin{array}{l}\text { for Recreation } \\
\text { No Supplemental Values }\end{array}$ \\
\hline 3 & 4 & Supplemental Values & 1 & 1 & $\begin{array}{l}\text { Intrusions Will Not } \\
\text { Rehabilitate }\end{array}$ \\
\hline 3 & 3 & $\begin{array}{l}\text { No Supporting Reasons } \\
\text { Offered }\end{array}$ & $\begin{array}{l}5 \\
11 \\
5\end{array}$ & $\begin{array}{l}5 \\
11 \\
5\end{array}$ & $\begin{array}{l}\text { Wilderness Study Comments } \\
\text { Resource Conflicts } \\
\text { Not Manageable as Wilderness }\end{array}$ \\
\hline & & & 7 & 7 & $\begin{array}{l}\text { No Supporting Reasons } \\
\text { Offered }\end{array}$ \\
\hline I & $\mathrm{s}$ & FORM LETTERS \& PETITIONS & $I$ & $\mathrm{~S}$ & FORM LETTERS \& PETITIONS \\
\hline
\end{tabular}

9596 Conservationists WSA Proposal for Las Cruces

25242659 Endorsements of Conservationist Proposal

\section{SEQUENCE NUMBERS}

F 014

$\mathrm{C} 030$

T001

$\mathrm{P} 025$

W033

N008

$\mathrm{S} 003$

B001

K005

2003

HO2O

L001

\section{SEQUENCE NUMBERS}

$\begin{array}{lll}\text { C031 } & \text { S030 } & \text { S054 } \\ \text { K024 } & \text { S 027 } & \text { H005 } \\ \text { F011 } & \text { S028 } & \text { S024 } \\ \text { F009 } & \text { B025 } & \text { G012 } \\ \text { F010 } & \text { B024 } & \text { S069 } \\ \text { C009 } & \text { B023 } & \text { C040 } \\ \text { C003 } & \text { S 053 } & \\ \text { D029 } & \text { F026 } & \\ \text { D007 } & \text { H003 } & \\ \text { I003 } & \text { S 034 } & \\ \text { H038 } & \text { C023 } & \\ \text { C033 } & \text { T020 } & \end{array}$

SEQUENCE NUMBER $\quad$ I $\quad S \quad$ COMMENTS

$\begin{array}{lllll}\text { W015 } & 1 & 1 & \text { Should be Reinventoried } \\ \text { P021 } & 1 & 1 & \text { " } \\ \text { M031 } & 1 & 1 & " 1 & " 1 \\ \text { E018 } & 1 & 1 & " 1\end{array}$


FAVOR

Wilderness Study

I $\quad S$
OPPOSE

Wilderness Designation or

Wilderness Study Status

\begin{tabular}{|c|c|c|}
\hline I & $\mathrm{S}$ & Supporting Reasons \\
\hline 7 & 7 & Over 5000 Acres \\
\hline 2 & 2 & $\begin{array}{l}\text { Meets Naturalness } \\
\text { Criterion }\end{array}$ \\
\hline 2 & 2 & $\begin{array}{l}\text { Offers Opportunities } \\
\text { for Solitude }\end{array}$ \\
\hline 1 & 1 & $\begin{array}{l}\text { Offers Opportunities } \\
\text { for Recreation }\end{array}$ \\
\hline 2 & 2 & $\begin{array}{l}\text { No Supporting Reasons } \\
\text { offered }\end{array}$ \\
\hline$I$ & $\mathrm{~S}$ & FORM LETTERS \& PETITIONS \\
\hline 95 & 96 & $\begin{array}{l}\text { Conservationists WSA } \\
\text { Proposal for Las Cruces }\end{array}$ \\
\hline 1 & 615 & $\begin{array}{l}\text { Petition endorsing Conser- } \\
\text { vationist Proposal }\end{array}$ \\
\hline
\end{tabular}

I S Supporting Reasons

11 Does Not Appear to Be

Natural

11 Intrusions are Sub-

stantially Noticeable

11 Offers No Opportunites

11 Offers No Opportunities

for Recreation

11 Not Manageable as Wilderness

I S FORM LETTERS \& PETITIONS

25242659 Endorsements of Conservationist Proposal

\section{SEQUENCE NUMBERS}

SEQUENCE NUMBERS

F014

L020

E020

W033

พ009

D010

L022

S035

F026

L001

S047 


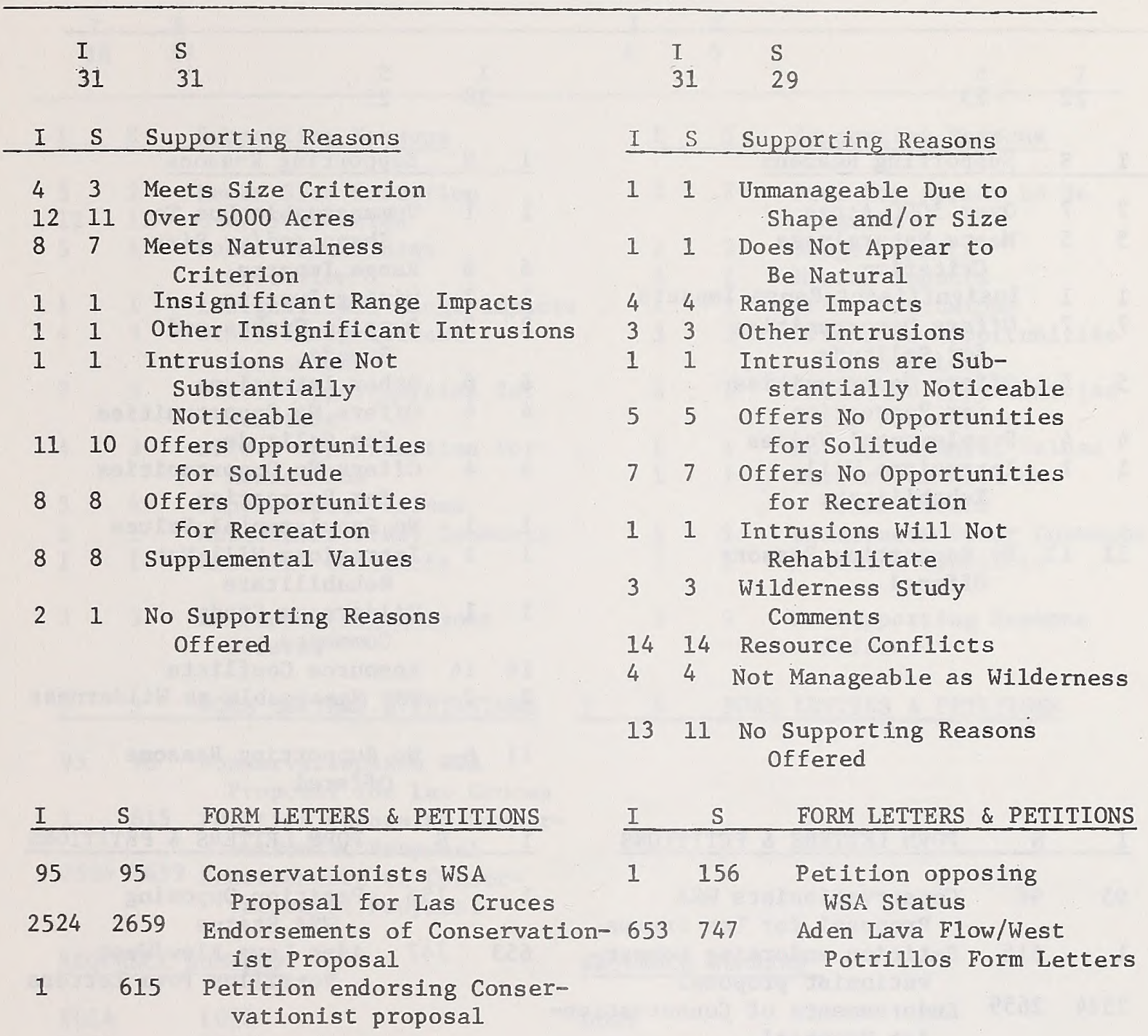

SEQUENCE NUMBERS

$\begin{array}{ll}\text { F014 } & \text { D010 } \\ \text { D028 } & \text { L022 } \\ \text { L020 } & \text { S035 } \\ \text { K017 } & \text { M031 } \\ \text { W015 } & \text { K005 } \\ \text { C002 } & \text { Z003 } \\ \text { G025 } & \text { S057 } \\ \text { K020 } & \text { L032 } \\ \text { P006 } & \text { G028 } \\ \text { B026 } & \text { H028 } \\ \text { W033 } & \text { C015 } \\ \text { K019 } & \text { H028 } \\ \text { H037 } & \text { A019 } \\ \text { B001 } & \text { S047 } \\ \text { P021 } & \text { L001 } \\ \text { W009 } & \end{array}$

SEQUENCE NUMBERS

$\begin{array}{ll}\text { G019 } & \text { W031 } \\ \text { G020 } & \text { H050 } \\ \text { C028 } & \text { S059 } \\ \text { K023 } & \text { E020 } \\ \text { B034 } & \text { S052 } \\ \text { O007 } & \text { D027 } \\ \text { D029 } & \text { D023 } \\ \text { P024 } & \text { F026 } \\ \text { W014 } & \text { S 060 } \\ \text { H038 } & 0001 \\ \text { S031 } & \text { P027 } \\ \text { S 050 } & \text { M048 } \\ \text { S051 } & \text { S001 } \\ \text { R014 } & \text { A001 } \\ \text { W038 } & \text { W027 }\end{array}$

H011

H039 


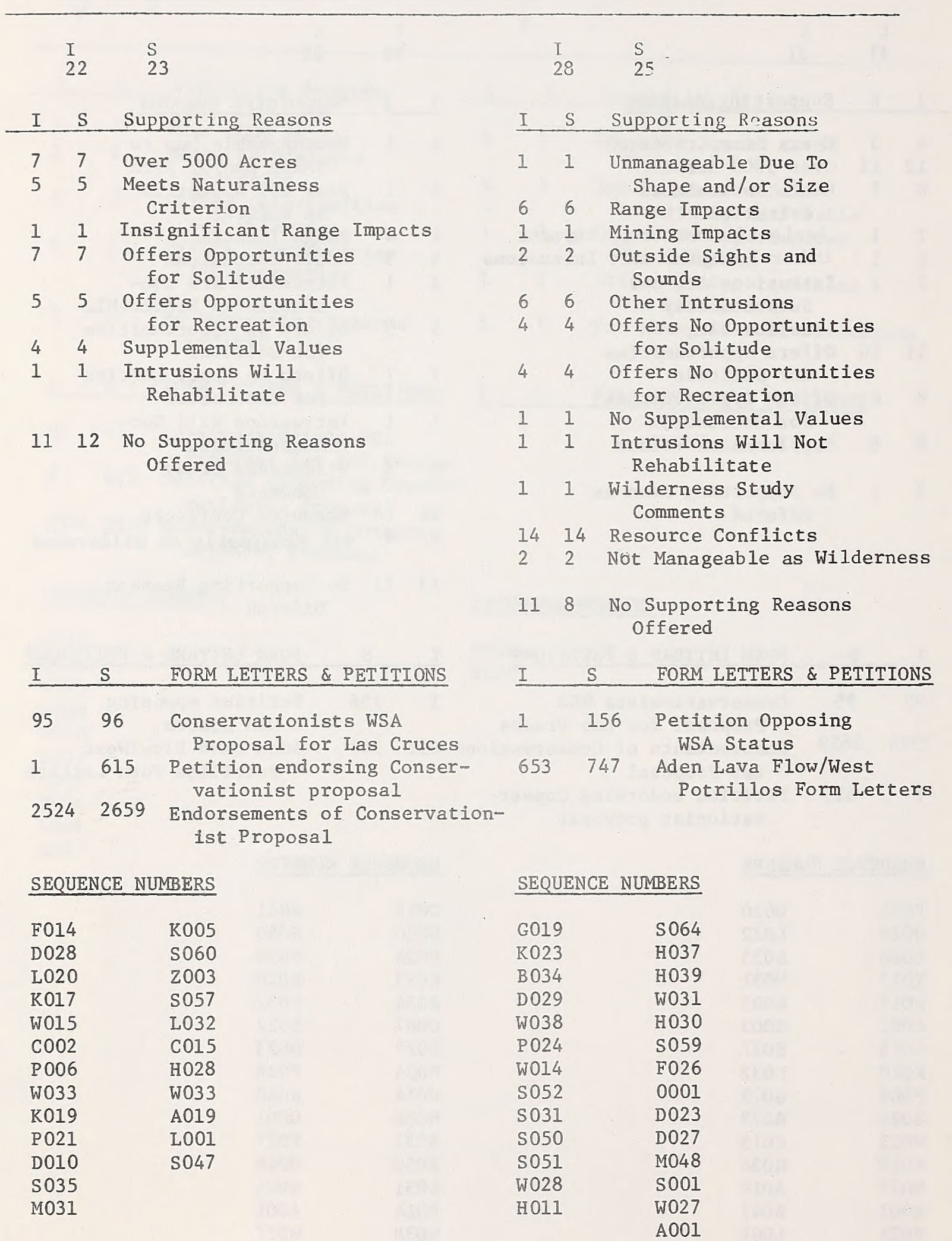


FAVOR

Wilderness Study
OPPOSE.

Wilderness Designation or Wilderness Study Status
I S

$18 \quad 17$
$\begin{array}{ll}I & S \\ 6 & 6\end{array}$

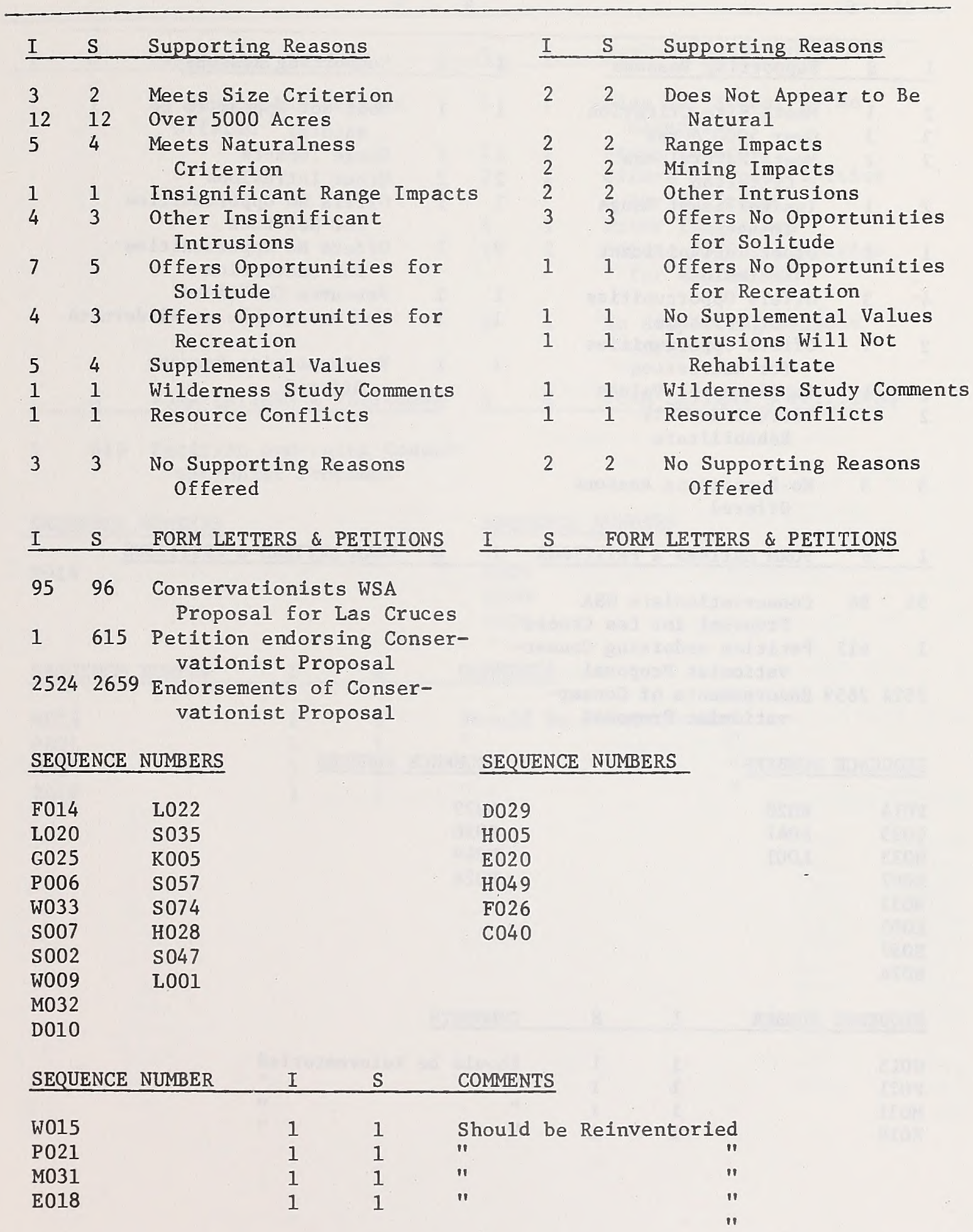


FAVOK

Wilderness Study

\section{(I)prost:}

Wilderness besignation or

Wilderness Study Status

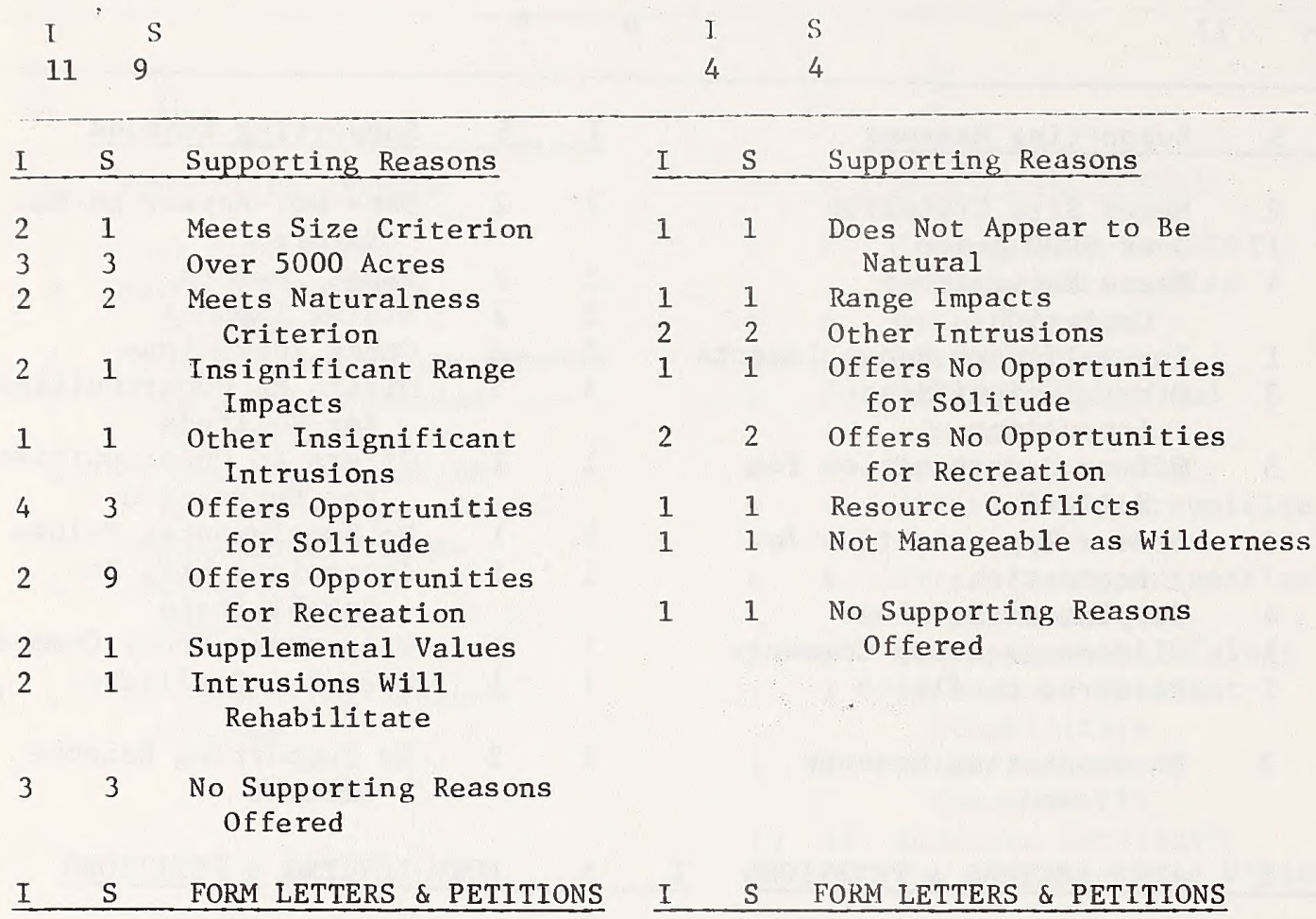

9596 Conservationists WSA

Proposal for Las Cruces

1615 Petition endorsing Conservationist Proposal

25242659 Endorsements of Conservationist Proposal

\section{SEQUENCE NUMBERS}

$\begin{array}{ll}\text { F014 } & \text { H028 } \\ \text { G025 } & \text { S047 } \\ \text { W033 } & \text { L001 } \\ \text { S007 } & \\ \text { M032 } & \\ \text { K005 } & \\ \text { S057 } & \\ \text { S074 } & \end{array}$

\section{SEQUENCE NUMBERS}

D029

E020

H049

F026

\begin{tabular}{lllll} 
SEQUENCE NUMBER & I & S & COMMENTS \\
\hline W015 & 1 & 1 & Should be Reinventoried \\
P021 & 1 & 1 & $" 1$ & $" 1$ \\
M031 & 1 & 1 & $" 1$ & $"$ \\
E018 & 1 & 1 & $" 1$
\end{tabular}


FAVOR

Wilderness Study

\section{OPPOSE}

Wilderness Designation or Wilderness Study Status

I S I I S

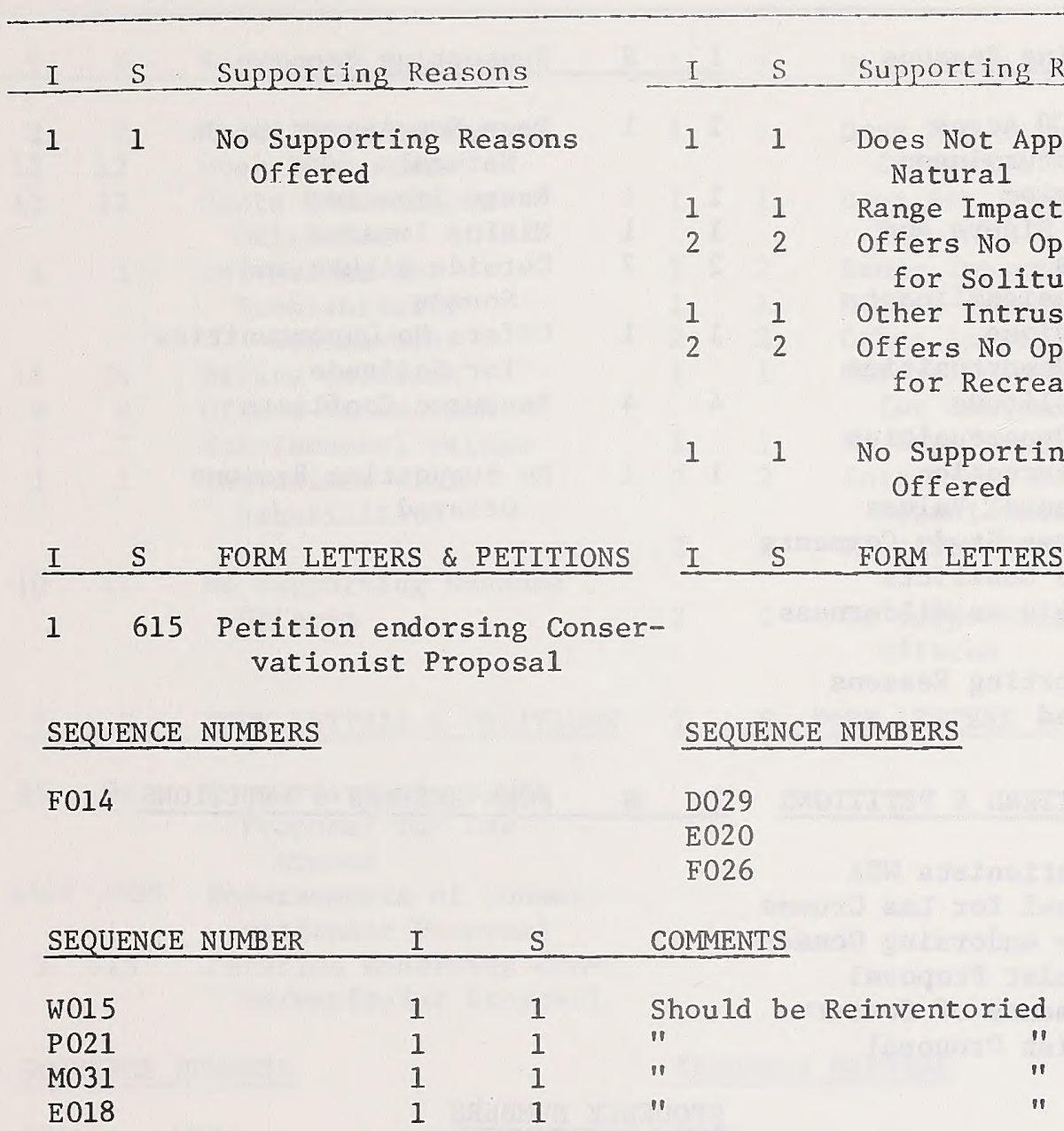




\section{Unit Number: NM-030-074 Unit Name: Mine House Spring}

FAVOR

Wilderness Study

I S

$21 \quad 22$
OPPOSE

Wilderness Designation or

Wilderness Study Status

\begin{tabular}{|c|c|c|}
\hline I & $\mathrm{S}$ & Supporting Reasons \\
\hline 8 & 8 & Over 5000 Acres \\
\hline 6 & 6 & $\begin{array}{l}\text { Meets Naturalness } \\
\text { Criterion }\end{array}$ \\
\hline 1 & 1 & $\begin{array}{l}\text { Outside Sights and } \\
\text { Sounds }\end{array}$ \\
\hline 1 & 1 & $\begin{array}{l}\text { Other Insignificant } \\
\text { Intrusions }\end{array}$ \\
\hline 8 & 8 & $\begin{array}{l}\text { Offers Opportunities } \\
\text { for Solitude }\end{array}$ \\
\hline 7 & 7 & $\begin{array}{l}\text { Offers Opportunities } \\
\text { for Recreation }\end{array}$ \\
\hline 6 & 6 & Supplemental Values \\
\hline 2 & 2 & Wilderness Study Comments \\
\hline 1 & 1 & Resource Conflicts \\
\hline 1 & 1 & Manageable as Wilderness \\
\hline 8 & 9 & $\begin{array}{l}\text { No Supporting Reasons } \\
\text { Offered }\end{array}$ \\
\hline
\end{tabular}

I $\quad S$

66

I S Supporting Reasons

11 Does Not Appear to Be Natural

11 Range Impacts

11 Mining Impacts

22 Outside Sights and

Sounds

11 Offers No Opportunities

for Solitude

44 Resource Conflicts

11 No Supporting Reasons offered

\section{S FORM LETTERS \& PETITIONS}

\section{S FORM LETTERS \& PETITIONS}

\section{Conservationists WSA Proposal for Las Cruces \\ 1615 Petition endorsing Conser- vationist Proposal}

25242659 Endorsements of Conservationist Froposa1

\section{SEQUENCE NUMBERS}

\section{SEQUENCE NUMBERS}

K023

0007

D029

E020

F026

0001 
FAVOR

Wilderness Study

\section{OPPOSE}

Wilderness Designation or

Wilderness Study Status

I S

$6 \quad 6$

I S Supporting Reasons

22 Meets Size Criterion

1212 Over 5000 Acres

1212 Meets Naturalness

Criterion

11 Intrusions Not Substantially Noticeable.

1414 . Offers Solitude

99 Offers Recreation

$7 \quad 7$ Supplemental Values

$1 \quad 1$ Intrusions Will

Rehabilitate

1011 No Supporting Reasons offered

\section{S FORM LETTERS \& PETITIONS}

9596 Conservationists WSA
Proposal for Las
Cruces

25242659 Endorsements of Conservationist Proposal

1615 Petition Endorsing Conservationist Proposal

SEQUENCE NUMBERS

$\begin{array}{ll}\text { F014 } & \text { W033 } \\ \text { L020 } & \text { D009 } \\ \text { K017 } & \text { D010 } \\ \text { P006 } & \text { S026 } \\ \text { B026 } & \text { S035 } \\ \text { K019 } & \text { C015 } \\ \text { S003 } & \text { S036 } \\ \text { P021 } & \text { W023 } \\ \text { M031 } & \text { M026 } \\ \text { K005 } & \text { K018 } \\ \text { Z003 } & \text { B029 } \\ \text { S057 } & \text { L02: } \\ \text { F026 } & \text { L001 } \\ \text { H028 } & \text { S047 }\end{array}$

\begin{tabular}{|c|c|c|}
\hline I & $\mathrm{S}$ & Supporting Reasons \\
\hline 1 & 1 & $\begin{array}{l}\text { Does Not Meet Size } \\
\text { Criterion }\end{array}$ \\
\hline 1 & 1 & $\begin{array}{l}\text { Does Not Appear to be } \\
\text { Natural }\end{array}$ \\
\hline 2 & 2 & Range Impacts \\
\hline 1 & 1 & Mining Impacts \\
\hline 2 & 2 & Other Intrusions \\
\hline 1 & 1 & $\begin{array}{l}\text { Offers No Opportunities } \\
\text { for Solitude }\end{array}$ \\
\hline 1 & 1 & No Supplemental Values \\
\hline 2 & 2 & $\begin{array}{l}\text { Intrusions Will Not } \\
\text { Rehabilitate }\end{array}$ \\
\hline 2 & 2 & Resource Conflicts \\
\hline 2 & 2 & $\begin{array}{l}\text { No Supporting Reasons } \\
\text { Offered }\end{array}$ \\
\hline
\end{tabular}

I S FORM LETTERS \& PETITIONS
SEQUENCE NUMBERS

M026

D002

H041

0001

D029

G029 
FAVOR
Wilderness Study

I S

$0 \quad 0$
OPPOSE

Wilderness Designation or Wilderness Study Status

$\begin{array}{ll}1 & S \\ 4 & 4\end{array}$
I S Supporting Reasons

SEQUENCE NUMBERS

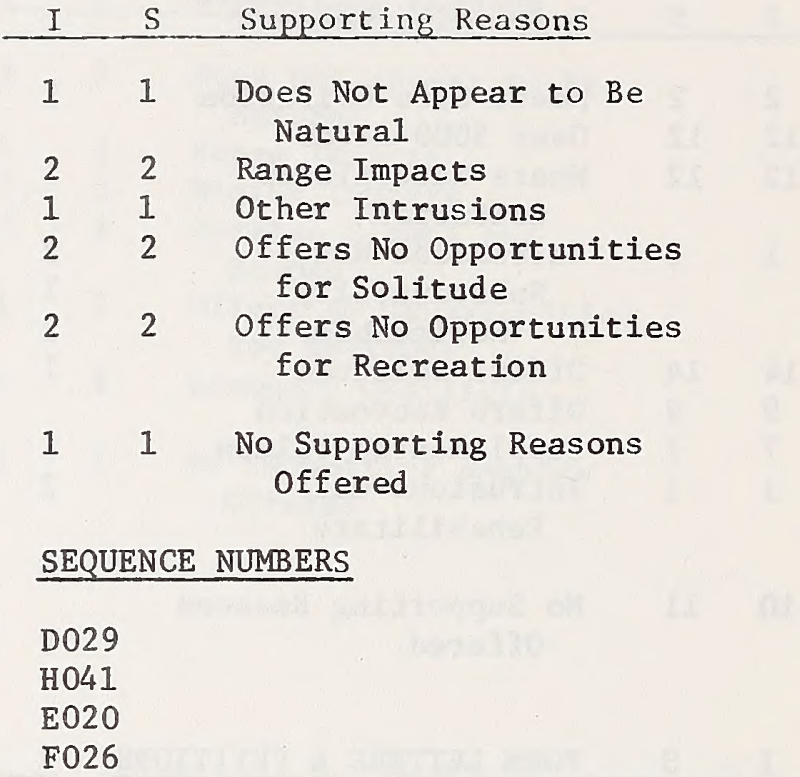


FAVOR

Wilderness Study

\section{OPPOSE}

Wilderness lesignation or Wilderness Study Status

I $\quad S$

$14 \quad 14$

$\begin{array}{ll}I & S \\ 0 & 0\end{array}$

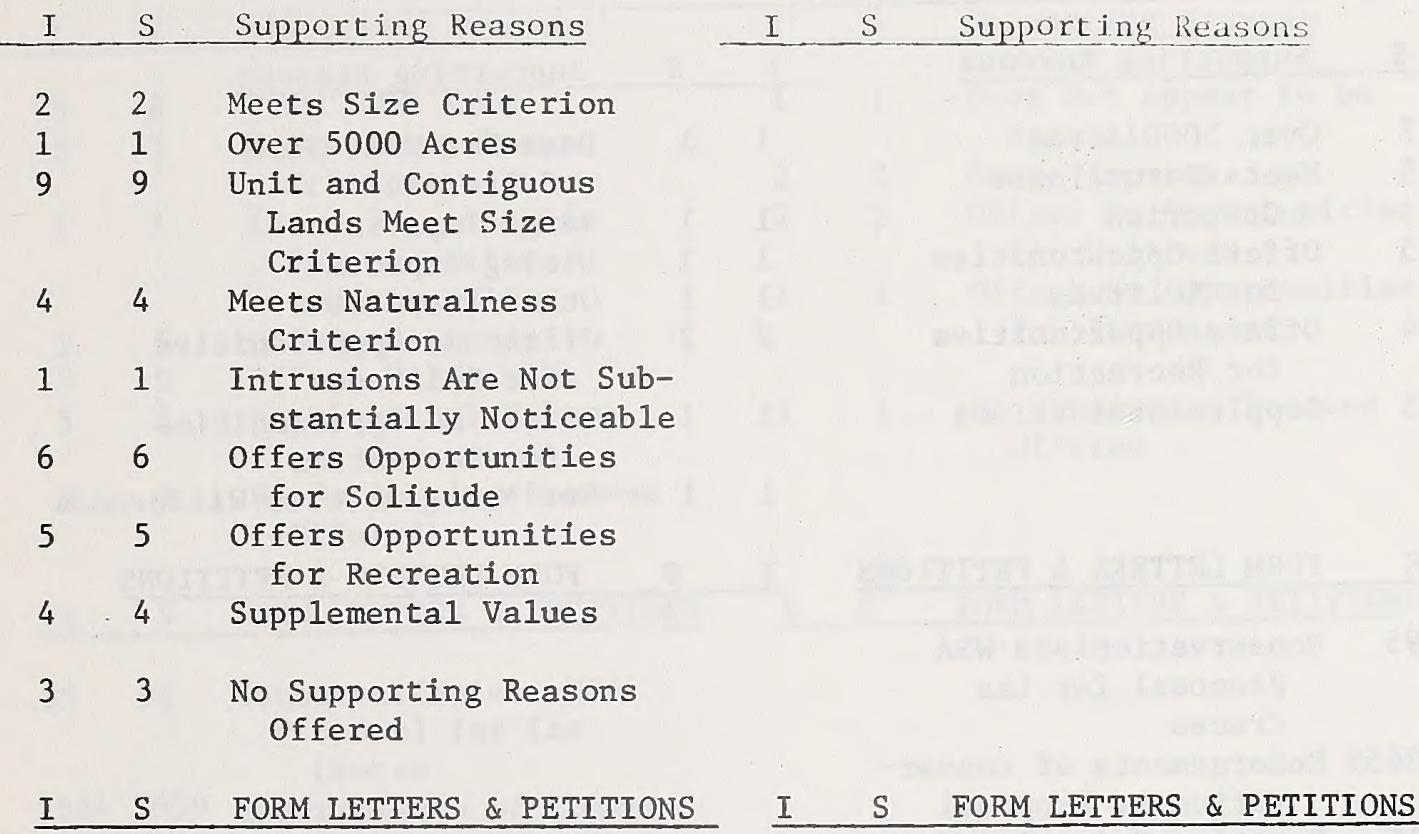

I S Supporting Reasons

9596 Conservationists WSA Proposa1

for Las Cruces

25242659 Endorsements of Conservationist Proposal

1615 Petition Endorsing Conservationist Proposal

\title{
SEQUENCE NUMBERS
}

\author{
SEQUENCE NUMBERS
}

L020

$\mathrm{C} 002$

G025

B026

W033

T017

W009

M032

D010

S035

K005

C012

H028

H042

S 047

L001 
FAVOR

Wilderness Study

I $\quad \mathrm{S}$

$18 \quad 19$

\section{OPPOSF}

Wilderness lesignation ot

Wilderness Study Status

\begin{tabular}{|c|c|c|}
\hline I & $\mathrm{S}$ & Supporting Reasons \\
\hline 7 & 7 & Over 5000 Acres \\
\hline 5 & 5 & $\begin{array}{l}\text { Meets Naturalness } \\
\text { Criterion }\end{array}$ \\
\hline 5 & 5 & $\begin{array}{l}\text { Offers Opportunities } \\
\text { for Solitude }\end{array}$ \\
\hline 4 & 4 & $\begin{array}{l}\text { Offers Opportunities } \\
\text { for Recreation }\end{array}$ \\
\hline 5 & 5 & Supplemental Values \\
\hline I & $\mathrm{S}$ & FORM LETTERS \& PETITI \\
\hline 95 & 95 & $\begin{array}{l}\text { Conservationists WSA } \\
\text { Proposal for Las } \\
\text { Cruces }\end{array}$ \\
\hline
\end{tabular}

25242659 Endorsements of Conservationist Proposal

1615 Petition Endorsing Conservationist Proposal

SEQUENCE NUMBERS

$\begin{array}{ll}\text { F014 } & \text { S057 } \\ \text { L020 } & \text { H028 } \\ \text { K017 } & \text { W033 } \\ \text { W015 } & \text { S047 } \\ \text { P006 } & \text { L001 } \\ \text { W033 } & \\ \text { K019 } & \\ \text { S007 } & \\ \text { P021 } & \\ \text { D010 } & \\ \text { S035 } & \\ \text { M031 } & \\ \text { K005 } & \\ \text { S060 } & \\ \text { Z003 } & \end{array}$

\section{SEQUENCE NUMBERS}

D029

J010

D006 


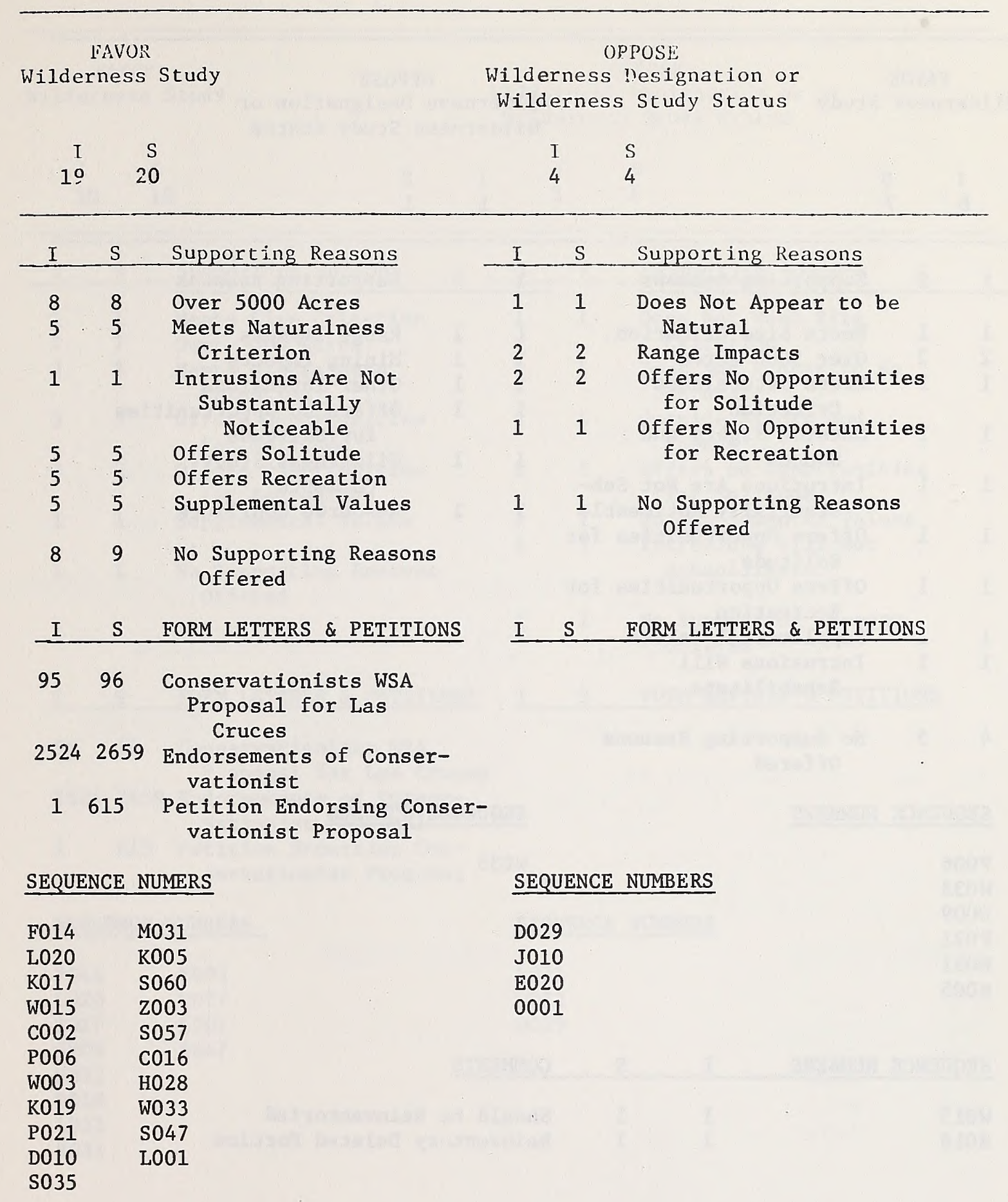


FAVOR

Wilderness Study

\section{OPPOSIE}

Wilderness nesignation or

Wilderness Study Status
I S
I S
$6 \quad 7$
11

\begin{tabular}{|c|c|c|}
\hline I & $\mathrm{S}$ & Supporting Reasons \\
\hline 1 & 1 & Meets Size Criterion \\
\hline 2 & 2 & Over 5000 Acres \\
\hline 1 & 1 & $\begin{array}{l}\text { Meets Naturalness } \\
\text { Criterion }\end{array}$ \\
\hline 1 & 1 & $\begin{array}{l}\text { Outside Sights and } \\
\text { Sounds }\end{array}$ \\
\hline 1 & 1 & $\begin{array}{l}\text { Intrusions Are Not Sub } \\
\text { stantially Noticeabl }\end{array}$ \\
\hline 1 & 1 & $\begin{array}{l}\text { Offers Opportunities } \\
\text { Solitude }\end{array}$ \\
\hline 1 & 1 & $\begin{array}{l}\text { Offers Opportunities f } \\
\text { Recreation }\end{array}$ \\
\hline 1 & 1 & Supplemental Values \\
\hline 1 & 1 & $\begin{array}{c}\text { Intrusions Will } \\
\text { Rehabilitate }\end{array}$ \\
\hline 4 & 5 & $\begin{array}{l}\text { No Supporting Reasons } \\
\text { offered }\end{array}$ \\
\hline
\end{tabular}

\section{SEQUENCE NUMBERS}

\section{SEQUENCE NUMBERS}

P006

W035

W033

0009

P021

M031

K005

\section{\begin{tabular}{llll} 
SEQUENCE NUMBERS & $I$ & $S$ & COMMENTS \\
\hline
\end{tabular}}

W015

E018

$1 \quad 1 \quad$ Should be Reinventoried

11 Reinventory Deleted Portion 
FAVOR

Wilderness Study

\section{OPPOSE}

Wilderness Designation or

Wilderness Study Status
I S

$10 \quad 10$
I S

3

\begin{tabular}{|c|c|c|}
\hline I & $\mathrm{S}$ & Supporting Reasons \\
\hline 1 & 1 & Meets Size Criterion \\
\hline 7 & 7 & Over 5000 Acres \\
\hline 3 & 3 & $\begin{array}{l}\text { Meets Naturalness } \\
\text { Criterion }\end{array}$ \\
\hline 3 & 3 & $\begin{array}{l}\text { Offers Opportunities } \\
\text { for Solitude }\end{array}$ \\
\hline 2 & 2 & $\begin{array}{l}\text { Offers Opportunities } \\
\text { for Recreation }\end{array}$ \\
\hline 1 & 1 & Supplemental Values \\
\hline 1 & 1 & $\begin{array}{l}\text { No Supporting Reasons } \\
\text { offered }\end{array}$ \\
\hline
\end{tabular}

I S FORM LETTERS \& PETITIONS

9596 Conservationists WSA Proposal for Las Cruces

25242659 Endorsements of Conservationist Proposal

1615 Petition Endorsing Conservationist Proposal

\section{SEQUENCE NUMBERS}

$\begin{array}{ll}\text { F014 } & \text { Z003 } \\ \text { L020 } & \text { S057 } \\ \text { T017 } & \text { L001 } \\ \text { W009 } & \text { S047 } \\ \text { M032 } & \\ \text { D010 } & \\ \text { L022 } & \\ \text { S035 } & \end{array}$

\begin{tabular}{|c|c|c|}
\hline$I$ & $\mathrm{~S}$ & Supporting Reasons \\
\hline 1 & 1 & $\begin{array}{l}\text { Does Not Meet Size } \\
\text { Criterion }\end{array}$ \\
\hline 1 & 1 & $\begin{array}{l}\text { Does Not Appear to } \mathrm{Be} \\
\text { Natural }\end{array}$ \\
\hline 1 & 1 & $\begin{array}{l}\text { Outside Sights and } \\
\text { Sounds }\end{array}$ \\
\hline 1 & 1 & $\begin{array}{l}\text { Offers No Opportunities } \\
\text { for Solitude }\end{array}$ \\
\hline 1 & 1 & No Supplemental Values \\
\hline 1 & 1 & $\begin{array}{l}\text { Intrusions Will Not } \\
\text { Rehabilitate }\end{array}$ \\
\hline 1 & 1 & $\begin{array}{l}\text { No Supporting Reasons } \\
\text { offered }\end{array}$ \\
\hline
\end{tabular}

I S FORM LETTERS \& PETITIONS

\section{SEQUENCE NUMBERS}

L021

W012

D029 
FAVOR

Wilderness Study
OPPOSE

Wilderness Designation or

Wilderness Study Status
I S
$10 \quad 10$
I S
6

\begin{tabular}{|c|c|c|}
\hline I & $S$ & Supporting Reasons \\
\hline 1 & 1 & $\begin{array}{l}\text { Does Not Meet Size } \\
\text { Criterion }\end{array}$ \\
\hline 2 & 2 & Range Impacts \\
\hline 1 & 1 & $\begin{array}{l}\text { Outside Sights and } \\
\text { Sounds }\end{array}$ \\
\hline 1 & 1 & Other Intrusions \\
\hline 1 & 1 & $\begin{array}{l}\text { Offers No Opportunities } \\
\text { for Solitude }\end{array}$ \\
\hline 1 & 1 & No Supplemental Values \\
\hline 1 & 1 & $\begin{array}{l}\text { Intrusions Will Not } \\
\text { Rehabilitate }\end{array}$ \\
\hline 2 & 2 & Resource Conflicts \\
\hline 3 & 3 & $\begin{array}{l}\text { No Supporting Reasons } \\
\text { offered }\end{array}$ \\
\hline I & $\mathrm{S}$ & FORM LETTERS \& PETITIONS \\
\hline
\end{tabular}

9596 Conservationists WSA Proposal for Las Cruces

25242659 Endorsements of Conservationist Proposal

1615 Petition Endorsing Conservationist Proposal

\section{SEQUENCE NUMBERS}

F014 S035

T017 2003

W009 $\quad 5057$

M032 H028

D010 5047

L022 L001
SEQUENCE NUMBERS

L024

K023

W012

D029

H017

0001 
Unit Number: NM-030-112C Unit Name: Broke off Mtns. (East)

FAVOR

Wilderness Study

I $\quad \mathrm{S}$

0

I $\mathrm{S}$

Supporting Reasons

\section{SEQUENCE NUMBERS}

\section{SEQUENCE NUMBERS}

D029

E020

OPPOSE

Wilderness Vesignation or

Wilderness Study Status

$$
\begin{array}{ll}
I & \text { S } \\
2 & 2
\end{array}
$$

I S Supporting Reasons

11 Does Not Appear to $\mathrm{Be}$

11 Offers No Opportunities

11 Offers No Opportunities

for Recreation

$1 \quad 1$ No Supporting Reasons 
HAVOR

Wilderness Study

$\begin{array}{lc}\mathrm{I} & \mathrm{S} \\ 17 & 18\end{array}$

\section{OPPOSl:}

Wilderness lesignation or

Wilderness Study Status

I 5

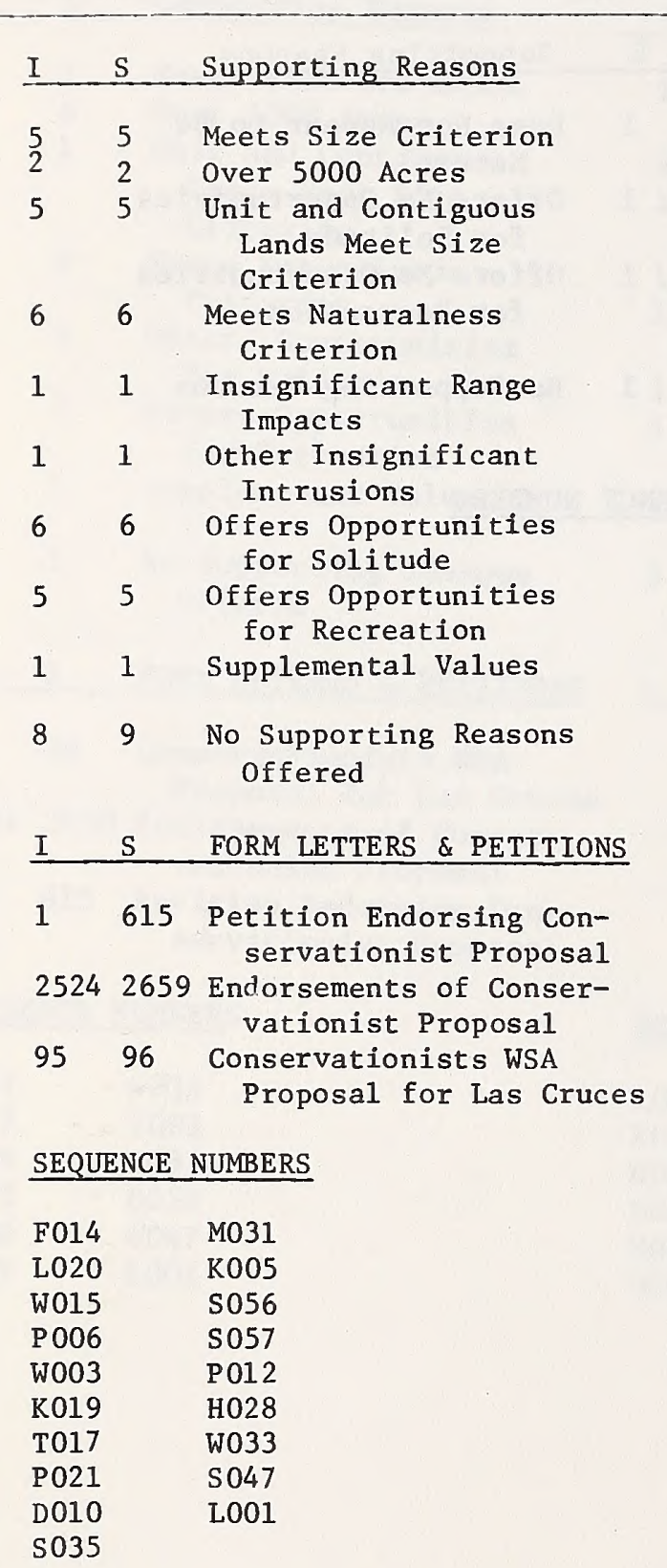

I S Supporting Reasons

22 Under 5000 Acres

22 Do Not Consider

Adjacent Lands

11 Outside Sights and

Sounds

11 Other Intrusions

22 Offers No Opportunities

for Solitude

22 Offers No Opportunities

for Recreation

11 Resource Conflicts

$1 \quad 1 \quad$ No Supporting Reasons offered

I S FORM LETTERS \& PETITIONS

\section{SEQUENCE NUMBERS}

L021

D029

S060

R021

0001 
FAVOR

Wilderness Study

I S

$8 \quad 8$
OPPOSE

Wilderness ?esignation or

Wilderness Study Status

\begin{tabular}{|c|c|c|}
\hline I & S & Supporting Reasons \\
\hline 1 & 1 & Meets Size Criterion \\
\hline 1 & 1 & Over 5000 Acres \\
\hline 4 & 4 & $\begin{array}{l}\text { Unit and Contiguous } \\
\text { Lands Meet Size } \\
\text { Criterion }\end{array}$ \\
\hline 2 & 2 & $\begin{array}{l}\text { Meets Naturalness } \\
\text { Criterion }\end{array}$ \\
\hline 1 & 1 & Other Insignificant \\
\hline 2 & 2 & $\begin{array}{l}\text { Offers Opportunities } \\
\text { for Solitude }\end{array}$ \\
\hline 2 & 2 & $\begin{array}{l}\text { Offers Opportunities } \\
\text { for Recreation }\end{array}$ \\
\hline 1 & 1 & Supplemental Values \\
\hline 3 & 3 & $\begin{array}{l}\text { No Supporting Reasons } \\
\text { offered }\end{array}$ \\
\hline$\underline{I}$ & $\mathrm{~S}$ & FORM LETTERS \& PETITIONS \\
\hline 95 & & $\begin{array}{l}\text { Conservationists WSA } \\
\text { Proposal for Las Cruces }\end{array}$ \\
\hline 2524 & 2659 & $\begin{array}{c}\text { Endorsements of Conser- } \\
\text { vationist Proposal }\end{array}$ \\
\hline 1 & 615 & $\begin{array}{l}\text { Petition Endorsing Con- } \\
\text { servationist Proposal }\end{array}$ \\
\hline \multicolumn{3}{|c|}{ SEQUENCE NUMBERS } \\
\hline L020 & & $\mathrm{C} 012$ \\
\hline W033 & & L001 \\
\hline - K019 & & S047 \\
\hline D010 & & \\
\hline S035 & & \\
\hline K005 & & \\
\hline S056 & & \\
\hline
\end{tabular}

$\begin{array}{ll}\text { I } & \text { S } \\ 3 & 3\end{array}$

I S Supporting Reasons

22 Do Not Consider

Adjacent Lands

11 Offers No Opportunities

for Solitude

11 Offers No Opportunities

for Recreation

11 No Supporting Reasons offered

I S FORM LETTERS \& PETITIONS

SEQUENCE NUMBERS

L021

R021

D001 
Unit Number: NM-030-124 Unit Name: Rim

FAVOR

Wilderness Study

$S$

$10 \quad 10$
OPPOSE

Wilderness nesignation or

Wilderness Study Status

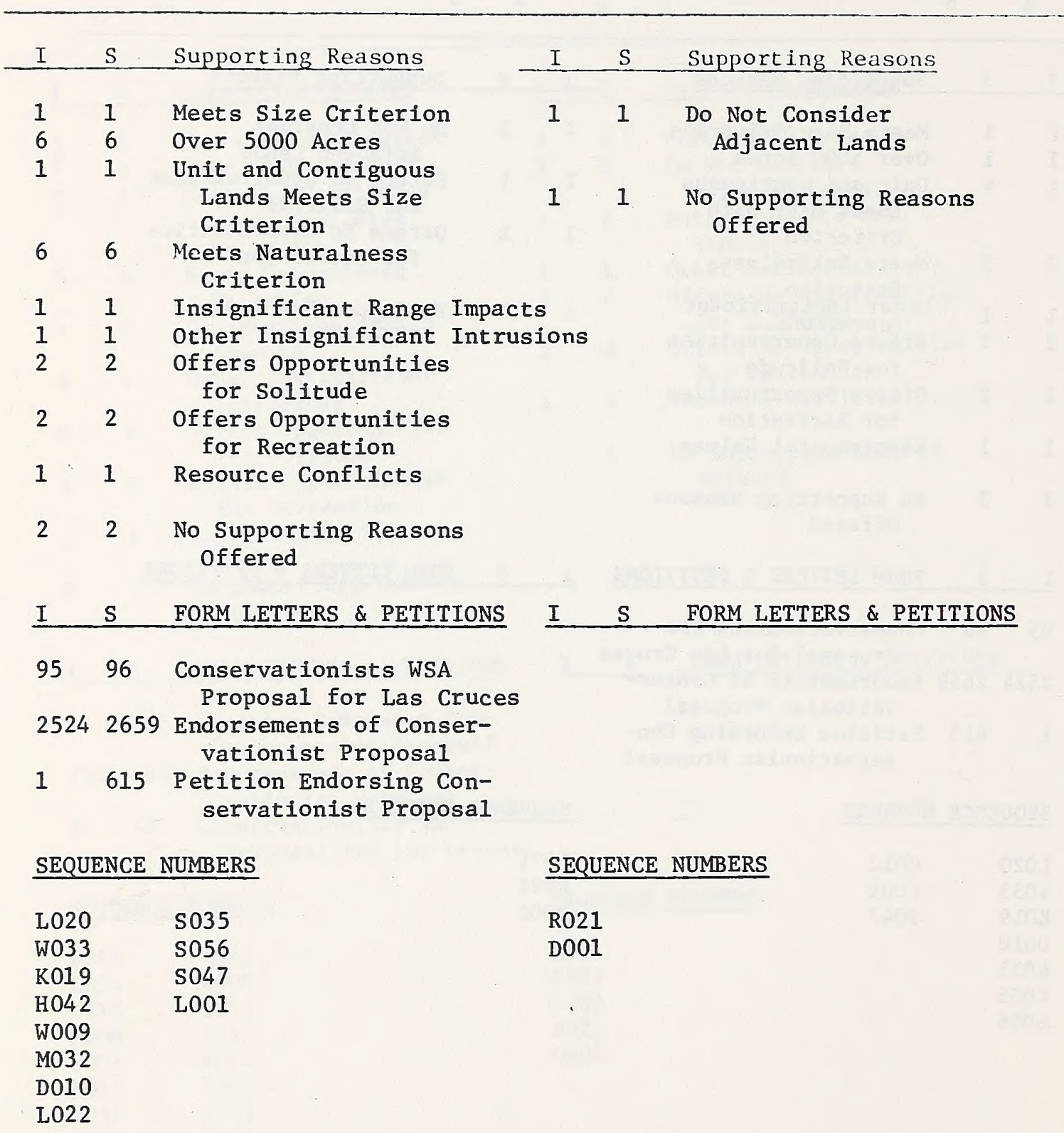


Unit Number: NM-030-135 Unit Name: Wind Mountain

PAVOR

Wilderness Study

\section{OPPOSE}

Wilderness lesignation or Wilderness Study Status
I S

11
$\begin{array}{ll}I & \text { S } \\ 2 & 2\end{array}$

\begin{tabular}{|c|c|c|}
\hline & $\mathrm{S}$ & Supporting Reasons \\
\hline 1 & 1 & Meets Size Criterion \\
\hline & 1 & $\begin{array}{l}\text { Meets Naturalness } \\
\text { Criterion }\end{array}$ \\
\hline 1 & 1 & $\begin{array}{l}\text { Insignificant Range } \\
\text { Impacts }\end{array}$ \\
\hline & 1 & $\begin{array}{l}\text { Other Insignificant } \\
\text { Intrusions }\end{array}$ \\
\hline & 1 & $\begin{array}{l}\text { Offers Opportunities } \\
\text { for Solitude }\end{array}$ \\
\hline
\end{tabular}

SEQUENCE NUMBERS

M039

SEQUENCE NUMBER I

$\begin{array}{ll}1 & 1 \\ 1 & 1 \\ 1 & 1 \\ 1 & 1\end{array}$

W015

P021

M031

E018

\section{S Supporting Reasons}

11 Does Not Appear to Be Natural

11 Other Intrusions

11 Intrusions Are Substantially Noticeable

22 Offers No Opportunities for Solitude

11 Offers No Opportunities for Recreation

\section{SEQUENCE NUMBERS}

D029

E020

COMMENTS

Should be Reinventoried
"1
"


FAVOR

Wilderness Study
OPPOSE

Wilderness Nesignation or Wilderness study Status
I S

11 $\begin{array}{ll}\text { I } & \text { S } \\ 2 & 2\end{array}$

\begin{tabular}{|c|c|c|}
\hline I & $\underline{s}$ & Supporting Reasons \\
\hline 1 & 1 & Meets Size Criterion \\
\hline 1 & 1 & $\begin{array}{l}\text { Meets Naturalness } \\
\text { Criterion }\end{array}$ \\
\hline 1 & 1 & $\begin{array}{l}\text { Insignificant Range } \\
\text { Impacts }\end{array}$ \\
\hline 1 & 1 & $\begin{array}{l}\text { Other Insignificant } \\
\text { Intrusions }\end{array}$ \\
\hline 1 & 1 & $\begin{array}{l}\text { Offers Opportunities } \\
\text { for Solitude }\end{array}$ \\
\hline
\end{tabular}

SEQUENCE NUMBERS

M039

SEQUENCE NUMBER

I

W015

P021

M031

E018

\section{S Supporting Reasons}

11 Does Not Meet Size

Criterion

11 Does Not Appear to Be

Natural

11 Offers No Opportunities for Solitude

22 Offers No Opportunities for Recreation

\section{SEQUENCE NUMBERS}

D029

E020

\section{COMMENTS}

Should be Reinventoried

"

"1 


\section{Unit Number: NM-030-137 Unit Name: Alamo Mountain}

WAVOR

Wilderness Study
I S
1313
I S
22

\section{S Supporting Reasons}

$\begin{array}{ll}1 & 1 \\ 9 & 9\end{array}$

Meets Size Criterion

Over 5000 Acres

44 Meets Naturalness

Criterion

11 Insignificant Range

Impacts

11 Insignificant Mining Impacts

11 Other Insignif1cant

$$
\text { Intrusions }
$$

11 Intrusions Are Not Substantially Noticeable

44 Offers Opportunities

for Solitude

22 Offers Opportunities

for Recreation

44 Supplemental Values

11 No Supporting Reasons offered

\section{S FORM LETTERS \& PETITIONS}

9596 Conservationists WSA

Proposal for Las Cruces

25242659 Endorsements of Conservationist Proposal

1615 Petition Endorsing Conservationist Proposal

SEQUENCE NUMBERS

$\begin{array}{ll}\text { F014 } & \text { D010 } \\ \text { L020 } & \text { L022 } \\ \text { W033 } & \text { S035 } \\ \text { M039 } & \text { K005 } \\ \text { B029 } & \text { Z003 } \\ \text { W007 } & \text { H028 } \\ \text { M032 } & \text { S047 } \\ \text { L001 } & \end{array}$

SEQUENCE NUMBERS

I S S

W015

$\mathrm{P} 021$

M031

E018
OPPOSE

Wilderness Designation or

Wilderness Study Status
11 Does Not Meet Size Criterion
11 Does Not Appear to Be
Natural
22 Offers No Opportunities
for Solitude
22 Offers No Opportunities for Recreation

I S FORM LETTERS \& PETITIONS

SEQUENCE NUMBERS

D029

E020 
Unit Number: NM-030-145 Unit Name: Devil's Den Canyon

FAVOR

Wilderness Study

I $\quad \mathrm{S}$

$13 \quad 13$
OPPOSE

Wilderness Designation or

Wilderness Study Status

\begin{tabular}{|c|c|c|c|c|c|}
\hline I & $\mathrm{S}$ & Supporting Reasons & $\mathrm{I}$ & $\mathrm{S}$ & Supporting Reasons \\
\hline 2 & 2 & Meets Size Criterion & & & . \\
\hline 1 & 1 & Over 5000 Acres & & & \\
\hline 9 & 9 & $\begin{array}{l}\text { Unit and Contiguous } \\
\text { Lands Meet Size } \\
\text { Criterion }\end{array}$ & & & \\
\hline 2 & 2 & $\begin{array}{l}\text { Meets Naturalness } \\
\text { Criterion }\end{array}$ & & & \\
\hline 2 & 2 & $\begin{array}{l}\text { Offers Opportunities } \\
\text { for Solitude }\end{array}$ & & & \\
\hline 2 & 2 & $\begin{array}{l}\text { Offers Opportunities } \\
\text { for Recreation }\end{array}$ & & & \\
\hline 1 & 1 & Supplemental Values & & & \\
\hline 5 & 5 & $\begin{array}{l}\text { No Supporting Reasons } \\
\text { Offered }\end{array}$ & & & \\
\hline$\underline{I}$ & $\mathrm{~s}$ & FORM LETTERS \& PETITIONS & $\underline{I}$ & $\mathrm{~S}$ & FORM LETTERS \& PETITIONS \\
\hline 95 & 96 & $\begin{array}{l}\text { Conservationists WSA } \\
\text { Proposal for Las Cruces }\end{array}$ & & & \\
\hline 2524 & 2659 & $\begin{array}{l}\text { Endorsement of Conser- } \\
\text { vationist Proposal }\end{array}$ & & & \\
\hline 1 & 615 & $\begin{array}{l}\text { Petition Endorsing Con- } \\
\text { servationist Proposal }\end{array}$ & & & \\
\hline
\end{tabular}

SEQUENCE NUMBERS

SEQUENCE NUMBERS

$\begin{array}{ll}\text { L020 } & \text { Z003 } \\ \text { B026 } & \text { C012 } \\ \text { W033 } & \text { H028 } \\ \text { W007 } & \text { W033 } \\ \text { M032 } & \text { L001 } \\ \text { D010 } & \text { S047 } \\ \text { L022 } & \\ \text { S035 } & \\ \text { K005 } & \end{array}$




\section{Unit Number: NM-030-146 Unit Name: McKittrick Canyon}

FAVOR

Wilderness Study
OPPOSE

Wilderness Designation or

Wilderness Study Status

I S

I S

$11 \quad 11$

I S Supporting Reasons

I S Supporting Reasons

11 Over 5000 Acres

$7 \quad$ Unit and Contiguous Lands Meet Size Criterion

22 Meets Naturalness

Criterion

22 Offers Opportunities for Solitude

22 Offers Opportunities for Recreation

11 Supplemental Values

33 No Supporting Reasons offered

I S F FORM LETTERS \& PETITIONS

I S FORM LETTERS \& PETITIONS

9596 Conservationists WSA Proposal for Las Cruces

25242659 Endorsements of Conservationist Proposal

1615 Petition Endorsing Conservationist Proposal

SEQUENCE NUMBERS

SEQUENCE NUMBERS

$\begin{array}{ll}\text { L020 } & \text { D010 } \\ \text { C002 } & \text { L022 } \\ \text { C012 } & \text { S035 } \\ \text { W033 } & \text { K005 } \\ \text { W009 } & \text { Z003 } \\ \text { M932 } & \text { L001 } \\ & \text { S047 }\end{array}$


FAVOR

Wilderness Study

I S

$16 \quad 17$
OPPOSE

Wilderness lesignation or

Wilderness Study Status

\begin{tabular}{|c|c|c|c|c|c|}
\hline I & S & Supporting Reasons & $\mathrm{I}$ & $\mathrm{S}$ & Supporting Reasons \\
\hline 2 & 2 & Meets Size Criterion & 1 & 1 & Offers No Opportunities \\
\hline 8 & 8 & Over 5000 Acres & & & for Solitude \\
\hline 2 & 2 & Unit and Contiguous & & & \\
\hline & & $\begin{array}{l}\text { Lands Meet Size } \\
\text { Criterion }\end{array}$ & 1 & 1 & $\begin{array}{l}\text { No Supporting Reasons } \\
\text { offered }\end{array}$ \\
\hline 4 & 4 & $\begin{array}{l}\text { Meets Naturalness } \\
\text { Criterion }\end{array}$ & & & \\
\hline 1 & 1 & $\begin{array}{l}\text { Intrusions Are Not } \\
\text { Substantially } \\
\text { Noticeable }\end{array}$ & & & \\
\hline 4 & 4 & $\begin{array}{l}\text { offers Opportunities } \\
\text { for Solitude }\end{array}$ & & & \\
\hline 4 & 4 & $\begin{array}{l}\text { Offers Opportunities } \\
\text { for Recreation }\end{array}$ & & & \\
\hline 2 & 2 & Supplemental Values & & & \\
\hline 1 & 1 & $\begin{array}{c}\text { Intrusions Will } \\
\text { Rehabilitate }\end{array}$ & & & \\
\hline 5 & 6 & $\begin{array}{l}\text { No Supporting Reasons } \\
\text { offered }\end{array}$ & & & \\
\hline I & $\mathrm{S}$ & FORM LETTERS \& PETITIONS & $I$ & $\mathrm{~S}$ & FORM LETTERS \& PETITIONS \\
\hline 95 & 96 & $\begin{array}{l}\text { Conservationists WSA } \\
\text { Proposal for Las Cruces }\end{array}$ & & & \\
\hline 2524 & 2659 & $\begin{array}{c}\text { Endorsements of Conser- } \\
\text { vationist Proposal }\end{array}$ & & & \\
\hline 1 & 615 & $\begin{array}{l}\text { Petition Endorsing Con- } \\
\text { servationist Proposal }\end{array}$ & & & 10 \\
\hline
\end{tabular}

\section{SEQUENCE NUMBERS}

SEQUENCE NUMBERS

$\begin{array}{ll}\text { F014 } & \text { L022 } \\ \text { L020 } & \text { S035 } \\ \text { W015 } & \text { M031 } \\ \text { P006 } & \text { K005 } \\ \text { W033 } & \text { S057 } \\ \text { T017 } & \text { H028 } \\ \text { W009 } & \text { H042 } \\ \text { M932 } & \text { S047 } \\ \text { D010 } & \text { L001 }\end{array}$

D029

SEQUENCE NUMBER $\quad I \quad S \quad$ COMMENTS

P021 111 Should be Reinventoried 


\section{Unit Number: NM-030-155 \\ Unit Name: Cress Garden}

LAVOR

Wilderness Study
OPPOSE

Wilderness nesignation or

Wilderness Study Status

I S

I S

$5 \quad 5$

2

I S S Supporting Reasons

11 Does Not Appear to $\mathrm{Be}$

Natural

11 Intrusions Are Sub-

stantially Noticable

11 Offers No Opportunities

for Solitude

11 Offers No Opportunities

for Recreation

\section{S FORM LETTERS \& PETITIONS}

I S FORM LETTERS \& PETITIONS

1615 Petition Endorsing Conservationist Proposal

\section{SEQUENCE NUMBERS}

L020

W009

M032

D010

$\mathrm{S} 035$

S047

\section{SEQUENCE NUMBERS}

D029

E020 
FAVOR

Wilderness Study

I S

\section{OPPOSE}

Wilderness !esignation or

Wilderness Study Status

\begin{tabular}{|c|c|c|}
\hline I & S & Supporting Reasons \\
\hline 1 & 1 & Meets Size Criterion \\
\hline 2 & 2 & Over 5000 Acres \\
\hline 5 & 5 & $\begin{array}{l}\text { Unit and Contiguous } \\
\text { Lands Meet Size } \\
\text { Criterion }\end{array}$ \\
\hline 2 & 2 & $\begin{array}{l}\text { Meets Naturalness } \\
\text { Criterion }\end{array}$ \\
\hline 1 & 1 & $\begin{array}{l}\text { Intrusions Are Not Sub- } \\
\text { stantially Noticeable }\end{array}$ \\
\hline 4 & 4 & $\begin{array}{l}\text { Offers Opportunities } \\
\text { for Solitude }\end{array}$ \\
\hline 3 & 3 & $\begin{array}{l}\text { Offers Opportunities } \\
\text { for Recreation }\end{array}$ \\
\hline 2 & 2 & Supplemental Values \\
\hline 1 & 1 & $\begin{array}{l}\text { Intrusions Will } \\
\text { Rehabilitate }\end{array}$ \\
\hline 1 & 1 & $\begin{array}{l}\text { No Supporting Reasons } \\
\text { offered }\end{array}$ \\
\hline$\underline{I}$ & $\mathrm{~S}$ & FORM LETTERS \& PETITIONS \\
\hline 95 & 96 & $\begin{array}{l}\text { Conservationists WSA } \\
\text { Proposal for Las Cruces }\end{array}$ \\
\hline 2524 & 2659 & $\begin{array}{c}\text { Endorsements of Conser- } \\
\text { vationist Proposal }\end{array}$ \\
\hline 1 & 615 & $\begin{array}{l}\text { Petition Endorsing Con- } \\
\text { servationist Proposal }\end{array}$ \\
\hline \multicolumn{3}{|c|}{ SEQUENCE NUMBERS } \\
\hline F014 & & K005 \\
\hline L020 & & HO28 \\
\hline W033 & & $\mathrm{H} 042$ \\
\hline T017 & & L001 \\
\hline D010 & & S047 \\
\hline
\end{tabular}

I S S Supporting Reasons

11 Unmanageable Due to

1 Shape and/or Siz

$1 \quad 1$ Offers No Opportunities for Solitude

11 No Supporting Reasons offered

I S FORM LETTERS \& PETITIONS

\section{SEQUENCE NUMBERS}

B019

0001 

Unit Number:
Unit Name:
Guadalupe Canyon Isa

FAVOR

Wilderness Study
OPPOSE

Wilderness nesignation or Wilderness study Status
$\begin{array}{ll}I & S \\ 5 & 5\end{array}$
$\begin{array}{ll}I & \text { S } \\ 3 & 3\end{array}$

\begin{tabular}{ccc}
$I$ & S & Supporting Reasons \\
\hline 1 & 1 & $\begin{array}{c}\text { Unit and Contiguous } \\
\text { Lands Meet Size } \\
\text { Criterion }\end{array}$ \\
1 & 1 & $\begin{array}{c}\text { Supplemental Values } \\
\text { Manageable as Wilderness }\end{array}$ \\
3 & 3 & $\begin{array}{c}\text { No Supporting Reasons } \\
\text { Offered }\end{array}$
\end{tabular}

\section{SEQUENCE NUMBERS}

\section{SEQUENCE NUMBERS}

F014

K017

M043

$\mathrm{C} 032$

$\mathrm{C} 034$

$\mathrm{C} 035$ 


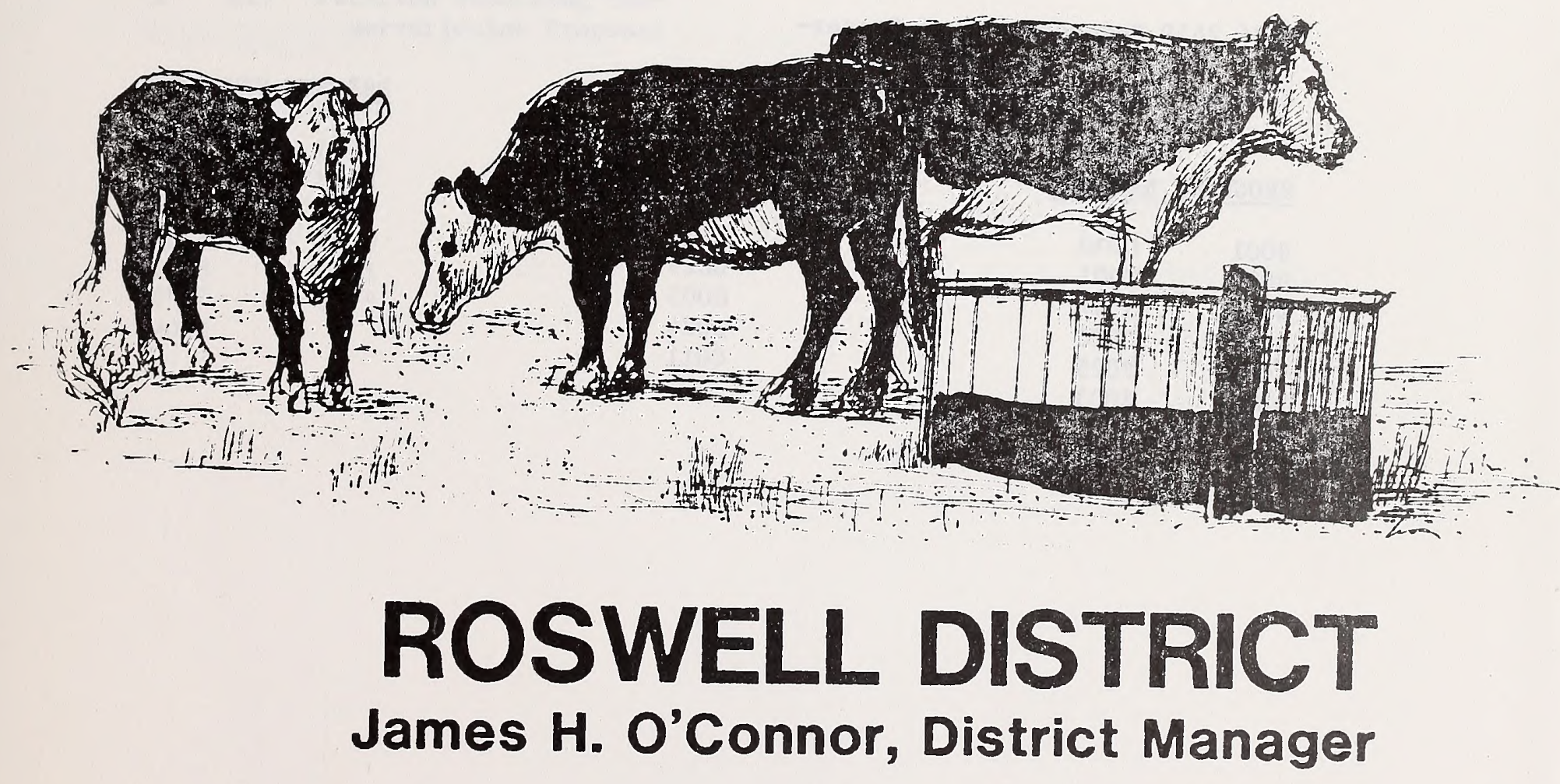


FAVOR

Wilderness Study
OPPOSE

Wilderness Vesignation or Wilderness Study Status

I S

$14 \quad 14$

I S

$5 \quad 5$

\begin{tabular}{|c|c|c|}
\hline I & S & Supporting Reasons \\
\hline 5 & 5 & Meets Size Criterion \\
\hline 3 & 3 & $\begin{array}{l}\text { Meets Naturalness } \\
\text { Criterion }\end{array}$ \\
\hline 1 & 1 & Insignificant Range Impa \\
\hline 1 & 1 & Insignificant ORV Damage \\
\hline 1 & 1 & $\begin{array}{l}\text { Intrusions Are Not Sub- } \\
\text { stantially Noticeable }\end{array}$ \\
\hline 4 & 4 & $\begin{array}{l}\text { Offers Opportunities } \\
\text { for Solitude }\end{array}$ \\
\hline 6 & 6 & Supplemental Values \\
\hline 1 & 1 & $\begin{array}{c}\text { Intrusions Will } \\
\text { Rehabilitate }\end{array}$ \\
\hline 6 & 6 & $\begin{array}{l}\text { No Supporting Reasons } \\
\text { offered }\end{array}$ \\
\hline I & $\mathrm{S}$ & FORM IETTERS \& PETITIONS \\
\hline 2524 & 2659 & $\begin{array}{c}\text { Endorsements of Conser- } \\
\text { vationist Proposal }\end{array}$ \\
\hline 1 & 615 & $\begin{array}{r}\text { Petition Endorsing Con- } \\
\text { servationist Proposal }\end{array}$ \\
\hline
\end{tabular}

\section{SEOUENCE NUMBERS}

$\begin{array}{ll}\text { B001 } & \text { C030 } \\ \text { B029 } & \text { T001 } \\ \text { W013 } & \text { S047 } \\ \text { K017 } & \text { L020 } \\ \text { P002 } & \text { F025 } \\ \text { D010 } & \text { Z003 } \\ \text { S035 } & \\ \text { H028 } & \\ \text { W033 } & \end{array}$

SEQUENCE NUMBERS

L014
D029
H005
D024
C011

H005

$\mathrm{C} 011$
I S FORM LETTERS \& PETITIONS

\section{Natural}

Range Impacts

Outside Sights and Sounds

Offers No Opportunities

for Recreation

No Supplemental Values

Resource Conflicts

W033 
FAVOR

Wilderness Study
OPPOSE

Wilderness Nesignation or

Wilderness Study Status
I S
$12 \quad 12$
I $\quad S$
22

\begin{tabular}{|c|c|c|}
\hline$I$ & $\mathrm{~S}$ & Supporting Reasons \\
\hline 1 & 1 & $\begin{array}{l}\text { Unit and Contiguous } \\
\text { Lands Meet Size } \\
\text { Criterion }\end{array}$ \\
\hline 2 & 2 & $\begin{array}{l}\text { Meets Naturalness } \\
\text { Criterion }\end{array}$ \\
\hline 2 & 2 & $\begin{array}{l}\text { offers Opportunities } \\
\text { for solitude }\end{array}$ \\
\hline 1 & 1 & $\begin{array}{l}\text { Offers Opportunities } \\
\text { for Recreation }\end{array}$ \\
\hline 2 & 2 & Supplemental Values \\
\hline 10 & 10 & $\begin{array}{l}\text { No Supporting Reasons } \\
\text { offered }\end{array}$ \\
\hline$I$ & $\mathrm{~S}$ & FORM LETTERS \& PETITIONS \\
\hline 2524 & 2659 & $\begin{array}{c}\text { Endorsements of Conser- } \\
\text { vationist Proposal }\end{array}$ \\
\hline 1 & 615 & $\begin{array}{l}\text { Petition Endorsing Con- } \\
\text { servationist Proposal }\end{array}$ \\
\hline
\end{tabular}

SEQUENCE NUMBERS

SEQUENCE NUMBERS

$\begin{array}{ll}\text { W013 } & \text { L020 } \\ \text { W009 } & \text { H028 } \\ \text { B001 } & \text { O001 } \\ \text { B026 } & \text { D010 } \\ \text { Z003 } & \text { S035 } \\ \text { S047 } & \text { F025 } \\ \text { W032 } & \end{array}$

I S S Supporting Reasons

11 Does Not Appear to Be

11 Range Impacts

11 Offers No Opportunities

11 Offers No Opportunities

for Recreation

22 Resource Conflicts

I S FORM LETTERS \& PETITIONS 
FAVOR

Wilderness Study

\begin{tabular}{rrrr}
$\mathrm{L}$ & $\mathrm{S}$ & $\mathrm{I}$ & $\mathrm{S}$ \\
10 & 10 & 9 & 9 \\
\hline
\end{tabular}

OPPOSE
I

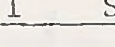

Supporting Reasons

11 Unit and Contiguous Lands Meet Size Criterion

1010 No Supporting Reasons offered

I S FORM LETTERS \& PETITIONS

4

$4 \quad 4$

$5 \quad 5$

55

99

88

11

11

3.3

44

33

I

25242659 Endorsements of Conservationist Proposal

1615 Petition Endorsing Conservationist Proposal

\section{SEQUENCE NUMBERS}

$\mathrm{K} 017$

W009

H028

D010

B001 L020

S035 0001

W033 F025

S047

\section{SEQUENCE NUMBERS}

$\begin{array}{ll}\text { W032 } & \text { L027 } \\ \text { B038 } & \text { S023 } \\ \text { O008 } & \text { E017 } \\ \text { B040 } & \text { C011 }\end{array}$

B039 
FAVOR

Wilderness Study
OPPOSE

Wilderness Nesignation or

Wilderness Study Status

\begin{tabular}{|c|c|c|}
\hline I & $\mathrm{S}$ & Supporting Reasons \\
\hline 2 & 2 & Meets Size Criterion \\
\hline 1 & 1 & $\begin{array}{l}\text { Meets Naturalness } \\
\text { Criterion }\end{array}$ \\
\hline 2 & 2 & $\begin{array}{l}\text { Offers Opportunities } \\
\text { for Solitude }\end{array}$ \\
\hline 2 & 2 & $\begin{array}{l}\text { Offers Opportunities } \\
\text { for Recreation }\end{array}$ \\
\hline 3 & 3 & Supplemental Values \\
\hline 8 & 8 & $\begin{array}{l}\text { No Supporting Reasons } \\
\text { Offered }\end{array}$ \\
\hline I & $\mathrm{S}$ & FORM LETTERS \& PETITIONS \\
\hline 2524 & 2659 & $\begin{array}{c}\text { Endorsements of Conser- } \\
\text { vationist Proposal }\end{array}$ \\
\hline 1 & 615 & $\begin{array}{l}\text { Petition Endorsing Con- } \\
\text { servationist Proposal }\end{array}$ \\
\hline
\end{tabular}

SEQUENCE NUMBERS

B001

S035

W013 F025

K006 W033

K017 H028

K018 L020

G001 D010

\begin{tabular}{|c|c|c|}
\hline I & $\mathrm{S}$ & Supporting Reasons \\
\hline 2 & 2 & $\begin{array}{l}\text { Do Not Consider Adjacent } \\
\text { Lands }\end{array}$ \\
\hline 4 & 4 & Range Impacts \\
\hline 2 & 2 & Outside Sights and Sounds \\
\hline 1 & 1 & $\begin{array}{l}\text { Offers No Opportunities } \\
\text { for Recreation }\end{array}$ \\
\hline 2 & 2 & Resource Conflicts \\
\hline
\end{tabular}

I S FORM LETTERS \& PETITIONS

\section{SEQUENCE NUMBERS}

K001

M033

D029

$\mathrm{C} 011$ 
FAVOR

Wilderness Study

I S
OPPOSE

Wilderness l)esignation or

Wilderness Study Status

\begin{tabular}{|c|c|c|}
\hline I & $\underline{S}$ & Supporting Reasons \\
\hline 2 & 2 & Meets Size Criterion \\
\hline 1 & 1 & $\begin{array}{l}\text { Meets Naturalness } \\
\text { Criterion }\end{array}$ \\
\hline 2 & 2 & $\begin{array}{l}\text { Offers Opportunities } \\
\text { for Solitude }\end{array}$ \\
\hline 2 & 2 & $\begin{array}{l}\text { Offers Opportunities } \\
\text { for Recreation }\end{array}$ \\
\hline 2 & 2 & Supplemental Values \\
\hline 9 & 9 & $\begin{array}{l}\text { No Supporting Reasons } \\
\text { offered }\end{array}$ \\
\hline I & $\mathrm{S}$ & FORM LETTERS \& PETITIONS \\
\hline 2524 & 2659 & $\begin{array}{c}\text { Endorsements of Conser- } \\
\text { vationist Proposal }\end{array}$ \\
\hline 1 & 615 & $\begin{array}{l}\text { Petition Endorsing Con- } \\
\text { servation Proposal }\end{array}$ \\
\hline
\end{tabular}

SEQUENCE NUMBERS

$\begin{array}{ll}\text { B001 } & \text { S035 } \\ \text { W013 } & \text { K019 } \\ \text { K006 } & \text { W033 } \\ \text { K017 } & \text { H028 } \\ \text { F025 } & \text { D010 } \\ \text { K018 } & \text { S047 } \\ \text { L020 } & \\ \text { G001 } & \end{array}$

\begin{tabular}{|c|c|c|}
\hline I & $\mathrm{S}$ & Supporting Reasons \\
\hline 2 & 2 & $\begin{array}{l}\text { Do Not Consider Adjacent } \\
\text { Lands }\end{array}$ \\
\hline 3 & 3 & Range Impacts \\
\hline 2 & 2 & $\begin{array}{l}\text { Outside Sights and } \\
\text { Sounds }\end{array}$ \\
\hline 1 & 1 & $\begin{array}{l}\text { Offers No Opportunities } \\
\text { for Recreation }\end{array}$ \\
\hline 2 & 2 & Resource Conflicts \\
\hline I & S & FORM LETTERS \& PETITIONS \\
\hline
\end{tabular}

\section{SEQUENCE NUMBERS}

K001

M033

D029

$\mathrm{C} 011$ 
FAVOR

Wilderness Study
OPPOSE

Wilderness nesignation or Wilderness Study Status
I S
I $S$
66
11

\begin{tabular}{ccc} 
I & S & Supporting Reasons \\
\hline 6 & 6 & $\begin{array}{c}\text { No Supporting Reasons } \\
\text { Offered }\end{array}$ \\
I & S & FORM LETTERS \& PETITIONS \\
\hline 2524 & 2659 & $\begin{array}{c}\text { Endorsements of Conser- } \\
\text { vationist Proposa1 }\end{array}$ \\
1 & 615 & $\begin{array}{c}\text { Petition Endorsing Con- } \\
\text { servationist Proposal }\end{array}$
\end{tabular}

\section{SEQUENCE NUMBERS}

SEQUENCE NUMBERS

M032

D029 
Unit Number: NM-060-819 819A Unit Name: Mudgetts

FAVOR

Wilderness Study

1010

$\begin{array}{cccc}\text { I } & \text { S } & \text { Supporting Reasons } \\ 1 & 1 & \begin{array}{c}\text { Unit and Contiguous } \\ \text { Lands Meet Size } \\ \text { Criterion }\end{array} \\ 1 & 1 & \begin{array}{c}\text { Meets Naturalness } \\ \text { Criterion } \\ \text { Offers Opportunities } \\ \text { for Solitude }\end{array} \\ 1 & 1 & 1 & \begin{array}{c}\text { Offers Opportunities } \\ \text { for Recreation }\end{array} \\ 8 & 8 & \begin{array}{c}\text { Supplemental Values } \\ \text { No Supporting Reasons } \\ \text { Offered }\end{array}\end{array}$

OPPOSE

Wilderness Nesignation or

Wilderness Study Status

\begin{tabular}{|c|c|c|}
\hline I & $\mathrm{s}$ & Supporting Reasons \\
\hline 3 & 3 & $\begin{array}{l}\text { Does Not Meet Size } \\
\text { Criterion }\end{array}$ \\
\hline 2 & 2 & Under 5000 Acres \\
\hline 2 & 2 & $\begin{array}{l}\text { Do Not Consider } \\
\text { Adjacent Lands }\end{array}$ \\
\hline 6 & 6 & $\begin{array}{l}\text { Does Not Appear to Be } \\
\text { Natural }\end{array}$ \\
\hline 5 & 5 & Range Impacts \\
\hline 9 & 9 & $\begin{array}{l}\text { Outside Sights and } \\
\text { Sounds }\end{array}$ \\
\hline 1 & 1 & $\begin{array}{l}\text { Offers No Opportunities } \\
\text { for Solitude }\end{array}$ \\
\hline 1 & 1 & $\begin{array}{l}\text { Offers No Opportunities } \\
\text { for Recreation }\end{array}$ \\
\hline 2 & 2 & No Supplemental Values \\
\hline 4 & 4 & $\begin{array}{l}\text { Intrusions Will Not } \\
\text { Rehabilitate }\end{array}$ \\
\hline 4 & 4 & Resource Conflicts \\
\hline I & $\mathrm{S}$ & FORM LETTERS \& PETITIONS \\
\hline
\end{tabular}

1615 Petition Endorsing Conservationist Proposal

25242659 Endorsements of Conservationist Proposal

\section{SEQUENCE NUMBERS}

$\begin{array}{ll}\text { B } 001 & \text { H028 } \\ \text { W013 } & \text { F025 } \\ \text { K017 } & \text { D010 } \\ \text { S035 } & \text { L020 } \\ \text { Z003 } & \text { S047 }\end{array}$

W033
$\begin{array}{ll}I & \text { S } \\ 9 & 9\end{array}$ 
FAVOR

Wilderness Study

I S

$13 \quad 13$

\section{OPPOSE}

Wilderness !esignation or

Wilderness Study Status

\begin{tabular}{|c|c|c|}
\hline I & $\mathrm{S}$ & Supporting Reasons \\
\hline 3 & 3 & $\begin{array}{l}\text { Meets Naturalness } \\
\text { Criterion }\end{array}$ \\
\hline 2 & 2 & $\begin{array}{l}\text { Offers Opportunities } \\
\text { for Solitude }\end{array}$ \\
\hline 2 & 2 & $\begin{array}{l}\text { Offers Opportunities } \\
\text { for Recreation }\end{array}$ \\
\hline 2 & 2 & Supplemental Values \\
\hline 10 & 10 & $\begin{array}{l}\text { No Supporting Reasons } \\
\text { offered }\end{array}$ \\
\hline I & $\mathrm{S}$ & FORM LETTERS \& PETITION \\
\hline 2524 & 2659 & $\begin{array}{l}\text { Endorsements of Conser- } \\
\text { vationist Proposal }\end{array}$ \\
\hline 1 & 615 & $\begin{array}{l}\text { Petition Endorsing Con- } \\
\text { servationist Proposal }\end{array}$ \\
\hline
\end{tabular}

\section{SEQUENCE NUMBERS}

$\begin{array}{ll}\text { W013 } & \text { S035 } \\ \text { W009 } & \text { Z003 } \\ \text { B001 } & 0001 \\ \text { B026 } & \text { L020 } \\ \text { F025 } & \text { W033 } \\ \text { K017 } & \text { D010 } \\ \text { S047 } & \text { H028 }\end{array}$

\begin{tabular}{|c|c|c|}
\hline I & $S$ & Supporting Reasons \\
\hline 1 & 1 & Range Impacts \\
\hline 1 & 1 & $\begin{array}{l}\text { Outside Sights and } \\
\text { Sounds }\end{array}$ \\
\hline 1 & 1 & Resource Conflicts \\
\hline
\end{tabular}

I S FROM LETTERS \& PETITIONS

SEQUENCE NUMBERS

$\mathrm{C} 011$ 
Input: Any information or opinion offered in either written or oral form at a specific time and place. One individual or group may author more than one input.

Insignificant Mining Impacts: Inputs favoring wilderness study for a particular unit occasionalTy conceded that the area had been impacted by mining activities, however, they argued that the impacts were either substantially unnoticeable, that the operator was in trespass, or that the boundary could be altered to exclude these impacts.

Insignificant ORV Damage: Inputs favoring wilderness study for a particular unit occasionaliy conceded that the area had been impacted by off-road vehicles, however, they argued that the impacts were either substantially unnoticeable or that the boundary could be altered to exclude these impacts.

Insignificant Range Impacts: Inputs favoring wilderness study for a particular unit occasionalTy conceded that an area had been impacted by range improvements (e.g., fences, stock tanks), however, they argued that the impacts were either substantially unnoticeable or that the boundary could be altered to exclude these impacts.

Naturainess: In order to qualify for wilderness study, an area must generalTy appear to have been affected primarily by the forces of nature, with the imprint of man's work substantially unnoticeable.

Other Insignificant Intrusions: Inputs favoring wilderness study for a particular unit occasionaliy conceded that the area had been impacted by a variety of miscellaneous intrusions (e.g., power lines, abandoned buildings), however, they argued that the impacts were either substantialiy unnoticeable or that the boundary could be altered to exclude these impacts.

Outside Sights and Sounds: Man-made sights and sounds originating from outside an inventory unit. These were not evaluated during the intensive inventory unless they were very obvious.

Recreation: The opportunities for nonmotorized and nondeveloped types of recreation activities. Outstanding opportunities for solitude or primitive and unconfined recreation were wilderness characteristics examined during the intensive inventory. Some examples of primitive and unconfined types of recreation are: hiking, backpacking, fishing, hunting, horseback riding, mountain climbing and photography.

Rehabilitation: The possibility of the imprint of man's work being reduced by either natural processes or by hand labor to a level judged to be substantially unnoticeable. The capability of man-made intrusions to rehabilitate was evaluated during the intensive inventory. 
Sequence Number: The code number assigned to a particular input. The first character of the sequence number is the last initial of the author.

Signature: The individuals who authored or signed an input. An input may' have more than one signature (e.g., a petition).

Solitude: The opportunities for a person to avoid the sights, sounds, and evidence of other people in the inventory unit. Outstanding opportunities for solitude or primitive and unconfined recreation were wilderness characteristics examined during the intensive wilderness inventory. Factors contributing to opportunities for solitude are vegetative screening, topographic relief, vistas and physiographic variety.

Supplemental Values: Features of ecolögical, geological, or other scientific, educational, scenic, or historical value that may be present in an inventory unit. These are not necessary criteria for wilderness suitability, as is stated in the Wilderness Act of 1964, but must be assessed during the intensive wilderness inventory.

Wilderness Study: Among the unit specific comments, numerous inputs, both pro and con, supported their opinions with reasons which should be considered during the study phase of the Wilderness Review Process. 
